Historic, Archive Document

Do not assume content reflects current scientific knowledge, policies, or practices. 





\section{SPECIAL INFORMATION}

PRICES named in this catalog cover packing, and are the lowest possible consistent with good quality.

SHIPMENTS-Where no instructions accompany order as to method of shipping, they will be made by Express or Parcel Post (insured) as seems most advisable, charges to be paid by purchaser.

ORDERS-You will want your Pecnies just as early as they are in proper condition to ship, and to avoid any possible delay, you should place your order immediately upon receipt of this catalog. Orders ars filled in rotation as received.

TERMS-Cash with order. Remittance to be made by postoffice order, express order, check or bank draft. C. O. D. orders will not be accepted.

Every variety is guaranteed absolutely true to name, and we exercise the greatest care in getting out your orders. However, Peonies will not produce typical blooms until the third year, as many fine double varieties throw single and semi-single flowers the first and second seasons, so withhold your decision until you have seen normal blooms.

Every variety is separately marked with a copper wired label, suitable for attaching to rod or stake, and our careful method of packing insures stock reaching destınation in gcod, healthy condition. With each package we send complete directions for planting, culture and care.

If you wish shipment made by Parcei Post, send 5c for each Iris and $10 \mathrm{c}$ for each Peony. If you send more than required, it will be refunded. 


\section{AN INVITATION}

We wish to extend to all flower lovers an invitation to visit The Sam Carpenter Cardens, at Oswego, Kansas.

Our Narcissus start blooming the last of February, and a succession of varieties extends the season for ten weeks.

Tulip time is one of the favorites of visitors, and our display of seven thousand Darwins in 30 named varieties is a sight you will want to linger with.

The Iris Pageant comes next and our twelve miles of beds contain a thousand varieties.

Our French Lilacs, of which we have growing fifty varieties, bloom with the Irises, and the Oriental Poppies add a big splash of barbaric splendor to the borders at the same time.

The new Delphiniums are the coming flowers, in fact they have already arrived and we have growing fifty varieties of Kelway's and Wrexam hybrids that are marvels.

Our Peony collection is probably the finest in the Southwest and includes most all of the high rating varieties.

Our collection of Tree Peonies is unique, but these flowers are usually too ambitious and bud so early that they got nipped and killed by late frosts.

We are importing this spring ten each of sixty varieties from Japan.

The Glorious Glads will keep the garden attractive during the summer, and the Dahlias will brighten the latter days of summer and the fall.

The lily pond, with its many coloured blosmi and teeming with fish of varied hues, is also an attraction.

The Rose Garden, the collection of 20 varieties of Japanese Maples and other rare shrubs, add interest.

Come and sae us-the latch string hangs out.

THE SAM CARPENTER GARDENS.

Oswego, Kansas.

\section{A FINE DISPIAY}

Mr. A. L. Cook, of Ottawa, Kansas, is beautifying a tract of ten acres of ground adjoining the Country Club at tnat place.

Mr. Cook is assembling one of the finest collections of Peonies in the world on this tract, and as many of them are now two year's old, they should make a splendid showing this spring.

Mr. Cook's planting of Hyacmths, Narcissus and Tulips includes uniform sized beds of every variety listed in this catalogue.

The blooming season at Ottawa will be eight or ten days later than Oswego, and Mr. Cook says all flower lovers who visit his place will be welcome.

We think a man is indeed a public penefactor who is willing to share all this beauty with his friends and visitors.

A visit to Ottawa during Tulip and Peony time will repay anyone. 


\section{PLANTS THAT GROW AND BLOOM}

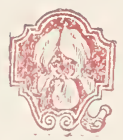

\section{TO THE GARDENING PUBLIC INCLUDING OUR PATRONS AND FRIENDS.}

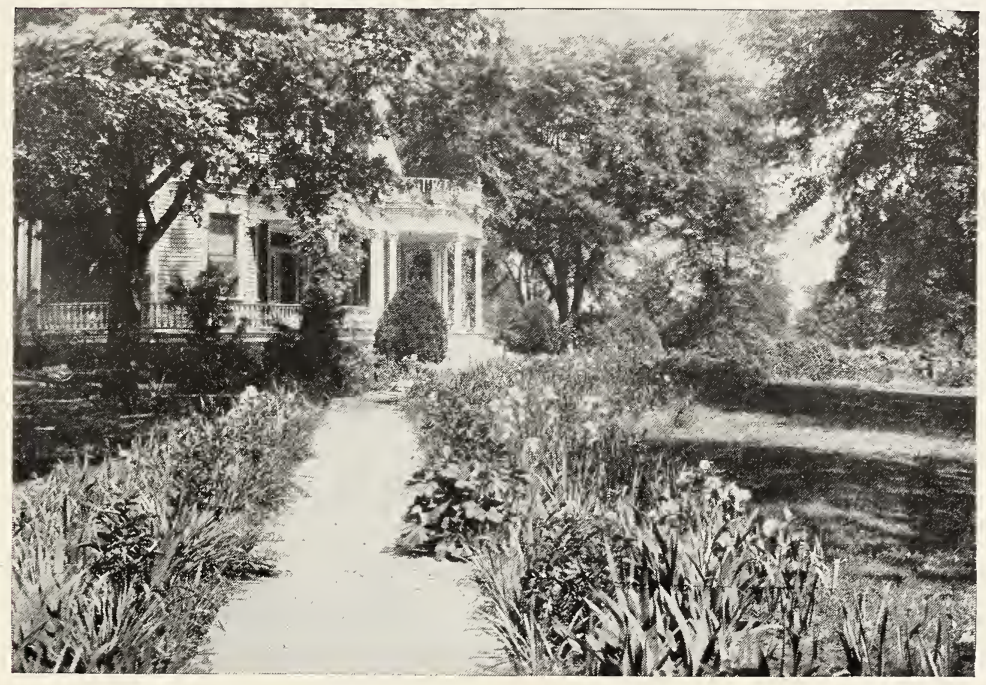

A GLIMPSE OF OUR PERENNIAL BORDERS.

狂 E ARE sending you this catalogue at the beginning of our third year in the commercial field and we hope it may help solve your garden and planting problems. We have been growing flowers successfully for pleasure for more than twenty-five years, and it is not necessary to tell those of you who also love their gardens what keen enjoyment it provides.

It is almost like when we were children and waiting in eager anticipation of the coming circus, to await the opening of our pageant of flowers. We live with them 'till dark, and are then up with the light of dawn to see what new buds have unfolded, what new treasures are revealed.

It is a real adventure to experiment with some new choice bulbs, plant or shrub, and the days of real sport are always with us as we find something considered difficult responding favorably to our ministrations.

We don't want to keep all this "fun and good times" to ourselves.

It is there for you, as well as for us if you start a garden, and if you already have a garden, try something new in it.

In the last few years interest in gardening and floriculture in this country has increased amazingly, but still we are away behind the English, the French and even the Japs in this regard. There is nothing more stabilizing in any country or community than home ownership and gardens. A garden will do a lot for you besides furnish flowers. It will rest tires nerves, restore your faith in God and man and purify your soul. We need more missionaries to spread the Gospel of flowers and gardens and believe they can accomplish as much good as missionaries to the heathen. 


\section{THE SAM CARPENTER GARDENS}

When men like President Harding, Harvey Firestone, Thomas Edison and Henry Ford sought the companionship each vacation of the great naturalist John Burroughs, until his death, they were the gainers and not Burrougins.

They knew how to conduct the affairs of government, to perform miracles in invention to achieve vast fortunes by their genius and efficiency, but it took the humble Burroughs at his little slabsides mountain home to open their eyes to the real treasures of earth with which God surrounds us, and which are as free to the humblest and poorest man that walks the earth as to the mightiest monarch.

We wish to contribute our mite to the betterment of mankind, and if we can interest you in some of the wonderful flowers listed in this catalogue, believe we are doing you a real service.

We are importing and growing hundreds of new flowers and plants each season, only a small part of which we are listing and offering for sale, but everything in this catalogue has been found reliable, and it is a survival of the fittest, for we have paid for the experimenting and only offer you what has proven the best.

It is appalling the number of men and wornen in this country otherwise cultured and sane, who pass through life without perceiving or at least appreciating the grandeur of God's out-of-doors, and the happiness, contentment and health, not to mention the beauty awaiting them in a garden.

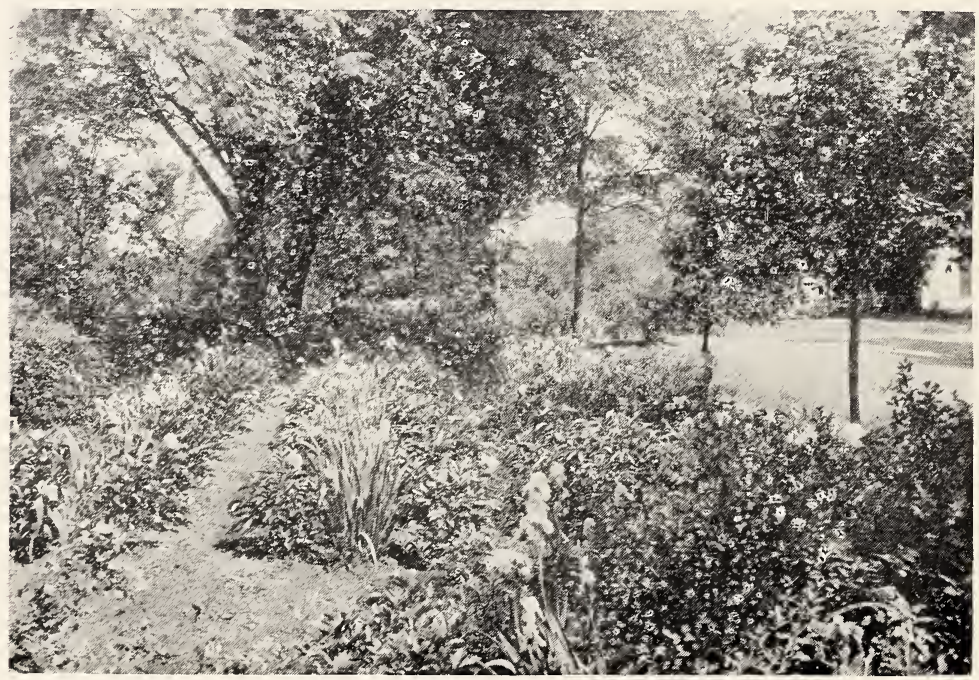

ELEVEN MILES OF IRIS BEDS IN OUR GARDENS. 


\section{The -

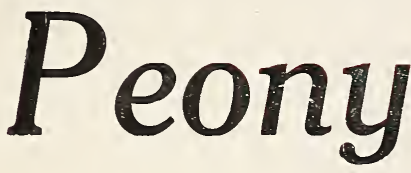

개

E ARE still faithful to our first love and believe the Peony the most beautiful flower ever created. A great many people have never seen one of the finer new Peonies, and if you have never beheld a bloom of Kelway's Glorious, Walter Faxon, Therese, LeCygne, Sarah Bernhardt, Souvenir de Louis Bigot, Milton Hill, Mary Brand, Mme. Jules Des-

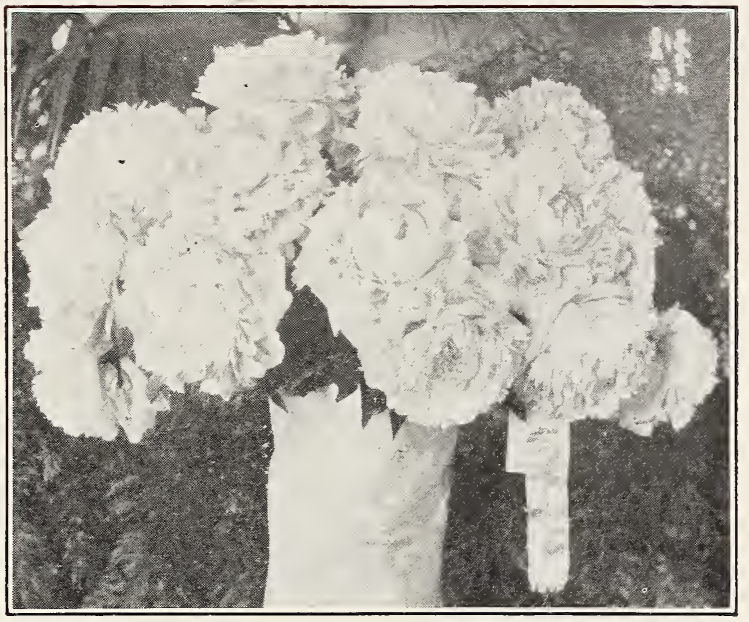

SARAH BERNHARDT (Lemoine) sert, or Tourangelle, you have something to live for, and when you gaze upon good specimens of these you will certainly behold God's most wonderful handiwork and wiil become an enthusiastic admirer of the Peony.

Another thing to commend the Peony is its ease of culture, being as hardy as an oak, when once established, and almost immune from disease.

The firest varieties are unsurpassed in beauty by any other flower with such richness and delicacy of coloring, elegance of form, enormous size and sweet perfume. It is splendid, both for the border and for bouquets in the house.

The Peony will grow, and give good returns in wonderful flowers each year, if the following simple instructions are followed in planting:

The soil, which should be rich, should be spaded deep, and well rotted manure can be put in the bottom of the hole, but no manure of any lind should come in direct contact with the roots.

Plant so the eyes are about two inches below the level of the surface and then mound up a little which can later be leveled by cultivation when tre shoots are up. We sprinkle a small handful of bone meal around each plant after the roots are covered with about an inch of soil.

If possible, plant in full exposure to the sun, and the Peony does best away from the roots of trees or shrubs, although we grcw it there in our borders.

Most Peonies that do not bloom, are planted too deep.

The Peony should be planted in the fall and we will start filling orders Sept. 15th.

Preceding the name of each variety we are giving the rating of the American Peony Society on its merits, 10.0 being perfect. We list very few ratings below 7.0 and these only because they are good shipping and keeping varieties, and popular with commercial growers for that reason. 
The date of introduction, where known, is given in brackets following name of variety. Where rating is not given, the variety is so recent or scarce that it has not yet been voted cn.

Our prices are for two to three or more eye divisions, with natural root system, or one year roots, which should bloom the first year sfter planting.

We have been criticized severely, especially by other growers, for listing too many varieties, but every Peony in this list is on some grower's preferred list of 60 to 100 varieties, and some Peonizs that we do not list or grow because they are rated so low by the American Pecny Society, are listed by some cf the growers who pride themselves because they only list the 60 to 100 best.

We do not desire or intend to grow or ofier for sale any Peony that we think deserves a rating below 70 , and above that they are all gocd, altho some are better than others.

Probably one-lalf our totsl volume of sales has bcen in selling these scarce or unusual varieties to other growers who do not now list them in their catalogues.

We believe our scil and climate, as well as other conditions are peculiarly adapted to raising superior Peonies and Irises, for nowhere else have we scen two year old plants of the size and vigor of ours, and we have scores of letters from customers, saying they never saw such big fat eyes on Pconies as the ones we sent.

Last fall the tops of all our Peonies were still green October 1st, and we did not start digging until late, and then coniinuous rains and floods for four weeks handicapped our digging and shipping, but this year we will start digging and shipping September 1st, and promise prompter and better service than last year.

We are offering a few collections this year which we can recommend.

Following Mr. Davis' new system of listing Glads, we are listing alphabetically like the names in a telephone book, for instance if you want to find David Harum, look under "H," and you will find it Harum, David.

We believe when this method is understood it will be universally adopted in indexing.

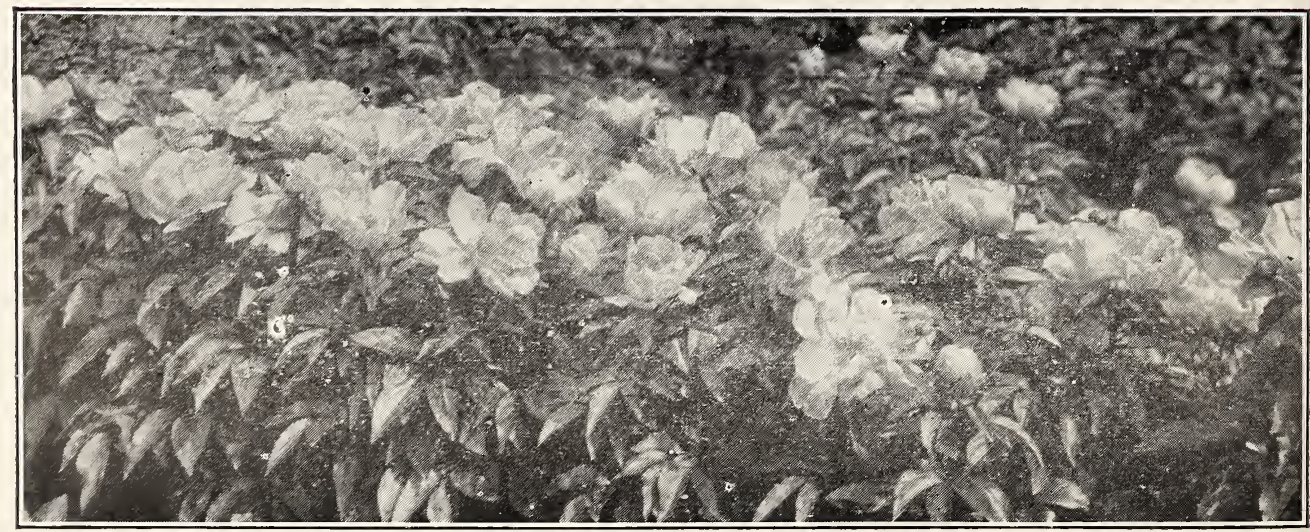

SINGLE PEONIES ARE VERY EFFJCTIVE IN MASS PLANTING. 


\section{PLANTS THAT GROW AND BLOOM}

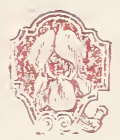

DESCRJPTIVE LIST OF THE

\section{PEONIES, CHINESE DOUBLE VARIETIES PAEONIA CHINENSIS.}

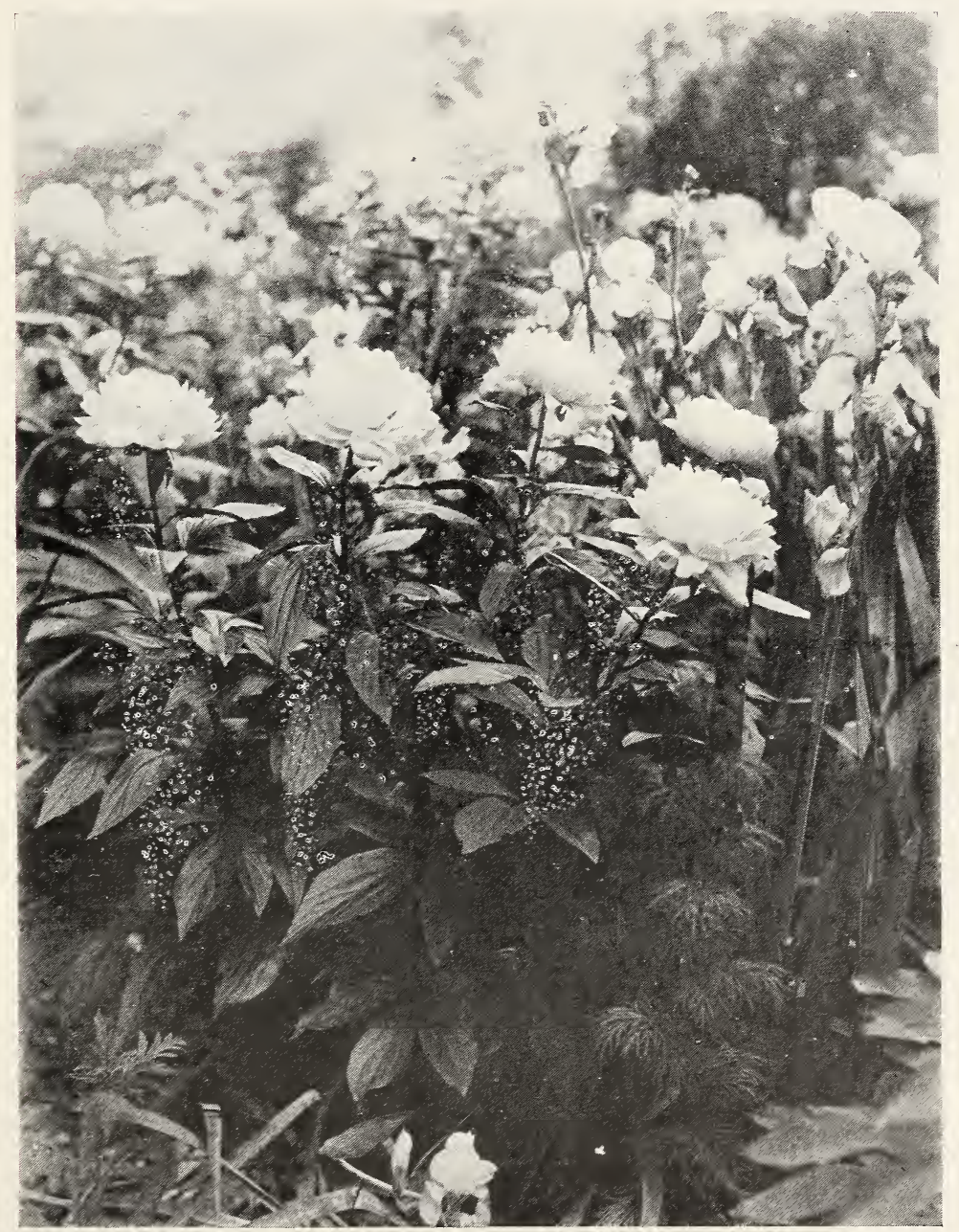

MRS. CHAS. S. MINOT (Description on page 12.)

8.8-ADDIELANCHEA (Brand) -_-_-_ $\$ 10.00$ Creamy-white, rose type, guard petals flecked crimson and crown petals slightly so. Base of center petals yellow. Fragrant.

8.8-ALSACE-LORRAINE (Lemoine 1906) -- 3.00 Very large, flat flower with petals arranged like those of a water lily. Creamy white with a golden halo. Tall and fine bloomer. Beautiful. Late.
AKSARBEN (Rosenfield 1908)--.-Large, flat, compact, semi-rose type; dark crimson; strong, erect, tall grower, mid-season; good.

8.7-AVALANCHE (Crousse 1886)--------carmine on the edge of the central petals. Fragrant. Late mid-season. Very good cut flower. A splendid white variety. 


\section{THE SAM CARPENTER GARDENS}

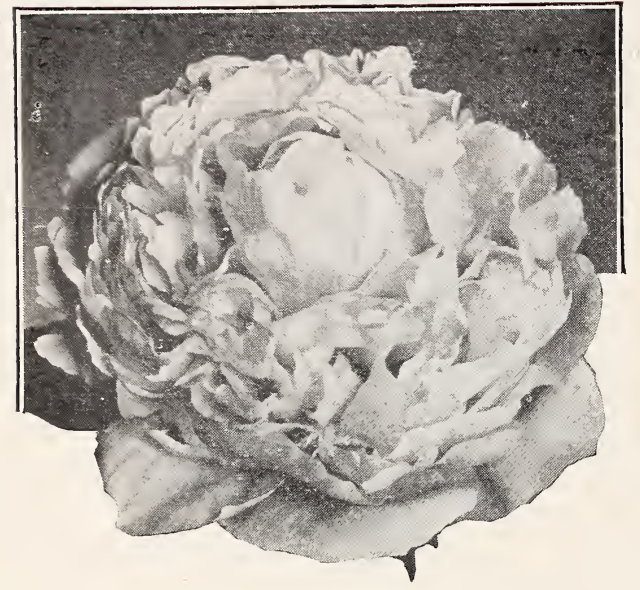

CLAIRE DUBOIS

(Description on page 9)

AUNT ELLEN (Brand)

Red. This variety comes into bloom just after Richard Carvel, which is the best early 1'ed. The flowers are large, loose semi-rose. The color is a rich purplish crimson. It can be depended upon to give good bloom every year.

8.1-AURORE (Dessert 1904)
Semi-rose type; late. Color lilac-white Semi-rose type; late. Color lilac-white crimson. Guards and center prominently flecked carmine.

8.1-BARNSBY, DR. H. (Dessert 1913)-_-- 2.00 Late. Rose type. Solferino red tinged purplish-crimson, changing to clearer tint with very pronounced bluish reflex. Strong stem. Free blooming in clusters.

BALL O' COTTON (Franklin)_________-_10.00 This new peony is recommended very highly by Mr. Bonnewitz and others who claim that it displays some of the best characteristics o f Jubilee and Glorious.

8.7-BAYADERE (Lem) 4.00 Large, loose, globular flowers of rose type; creamy-white with a golden heart. Very distinct and beautiful. Mid-season.

9.0-BERNHARDT, SARAH (Lemoine 1906) Semi-rose type; late mid-season. Very large flower of perfect form, full and double with twisted imbricated petals. Color apple blossom pink with each petal silver tipped. Strong grower, free bloomer and very fragrant. one of the finest and most dependable Peonies ever produced, attracting attention in every garden.
BERRY, JUDGE (Brand 1907)

5.00 Medium tall,, producing a profusion of large pink and white blooms of surpassing "beäuty." - Delicate. fragrance and very early.

BEAUMARCHAIS (Lemoine 1923)

Large, imbricated flowers, pink flushed mauve. A tall late flowering sort.

7.9-BEAUTY'S MASK (Hollis 1904) 1.50 Late, crown type. Clear bluish-white, tinted lilac with a few pale yellow petaloids showing. Fragrant.

BERTRADE (Lemoine) Very large, compact, globular, rose type. Erect, medium compact habit. Late. Extra good.

BIEBRICH (G. \& K. 1912) Very large flesh-colored bloom of flat rose type. Late.

BISHOP BURKE (Vories 1924) 40.00 One of the most beautiful red peonies. A shade of crimson with a silvery sheen. The petals are all waves and entirely different from all others and yet the blossom is perfect in form, absolutely distinct. One of the finest landscape varieties.

8.3--BIGOT, EUGENE (Dessert 1896) Semi-rose type. Late mid-season. Large imbricated flowers of perfect shape, bright "brilliant" red "with velvety garnet shades. Extra.

8.5-BIGOT, GERMAINE (Dessert 1902) --- 1.00 crown type. Mid-season. Very large, flat, delicate lilac-rose bloom. Guards and collar splashed with crimson.

8.0-BOULE DE NEIGE (Calot 1867)_-_-_- .50 Literally a ball of snow. Erect tall grower. Good cut flower variety.

EOY KELWAY (1916)

Wonderful flower of a dark shade of rose, contrasting well with the narrow, straight yellow center petals. A gem.

9.0-BONHEUR, ROSA (Dessert 1905)_-_-- 4.00 Very large, flat flower of rose type. Lovely soft flesh-pink. Strong grower, rather dwarf, with bushy habit. Free

bloomer. One of the finest. Mid-season.

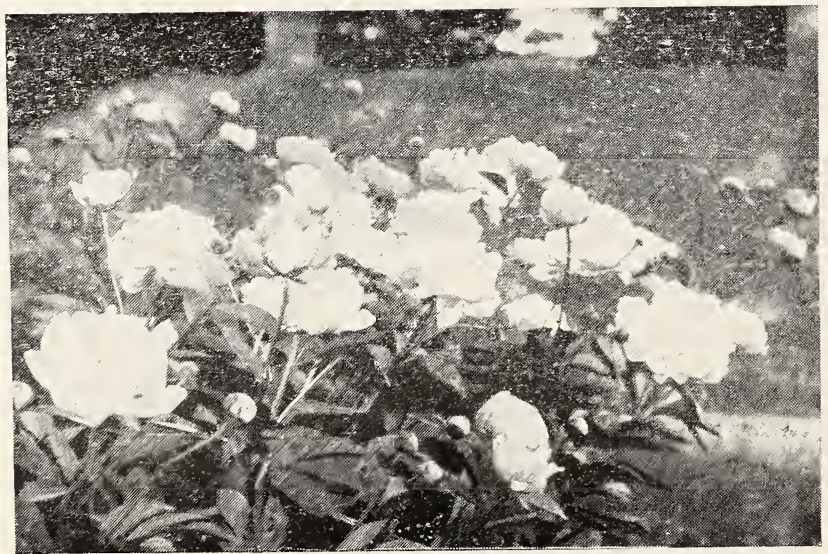




\section{PLANTS THAT GROW AND BLOOM}

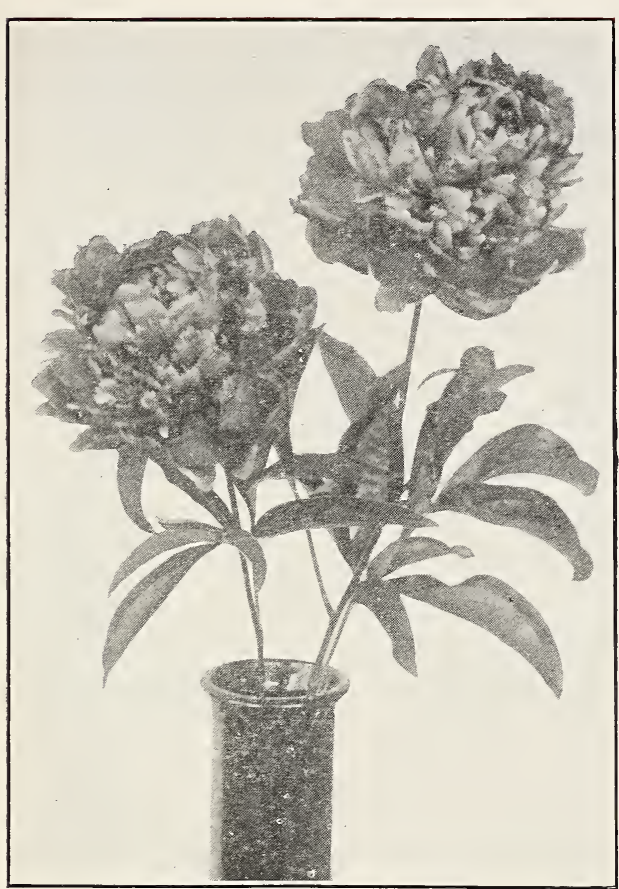

SOUT. DE LOUIS BIGOT

(Description on page 17.)

8.1-BRAND, RUTH (1907)

Very large pink of compact bomb shape. Tall stems holding a single bloom. Beautiful in bud and as a cut flower. Fragrant.

8.7-BRAND, MARY (1907)

A free blooming red of large size. Midseason.

\section{7-BRAND'S MAGNIFICENT (1918)-}

Probably Brand's best red peony. Medium height, mid-season, profuse bloomer. Petals all large like those of a rose. Deep dark red of bluish cast.

7.8-BOULANGER, MME. (Crousse 1886) --- 1.00 Rose type, late mid-season. Color glossy tender rose, shading to heliotrope bordered with silvery flesh. Extra fine.

9.1-BULLOCH, MARTHA (Brand 1907)_-- 7.00 The largest of the good peonies, producing mammoth cup-shaped blossoms often 9 to 12 inches across on strong erect stems. Late. Pink, fragrant.

8.9-BOYD, JAS. (Thurlow 1919)

Flesh, changing to nearly white, tinted at base of petals with yellowish salmon. Fragrant.

9.2-BROWNING, E. B. (Brand 1907) A superb late white, very large flowers of semi-rose type. Delightfully fragrant and one of the best for cut flowers.

BRITISH EMPIRE (Kelway) One of Kelmay's new race of Imperial peonies. A lovely semi-double, bright clear rose, broad petals, gold central petaloids.
8.8-CAREY, PHOEBE (Brand 1907)_-_...-6.00 A very fine pink of true rose type with large broad petals of good substance. Fragrant, late.

CANDEUR (Dessert 1920) Large globular, delicate silvery-pink, slightly tinged lilac-rose, fading an iridescent white, center flecked with carmine. Vigorous grower and fine clear green goliage.

8.8-CARVEL, RICHARD (Brand 1913)-_-- 4.00 An immense early red of bomb type. Pleasant fragrance.

8.6-CARSTENSEN, SARAH (Terry 1901) -- 3.00 Mid-season; rose type. Soft delicate rose with crimson streaked center. Dwarf but sturdy. Tery fine and scarce.

CAVEL, EDITH (Kelway 1917)_.........Milky-white guard petals, with a cushion of soft yellow; petals slightly tinted carmine, sweet scented.

8.5-CALOT, MME. JULES (Calot 1868)_-.-Semi-rose type; mid-season. Large compact, double flower, lilac-white narrow petals in collar mith a tuft of white petals laid on in splashes. Tall, good habit, fine bloomer.

8.1-CALOT, MLLE. LEONI (1861)-----A large flower of typical rose type. Very large salmon-pink, almost bluish-wbite, with center shading deeper. A delicate and beautiful color combination. Distinct and desirable. Late, mid-season.

8.1-CALOT, MME. (Meillez 1856) -.----Very large, rose type. Flesh-pink with orous. Good for cut flowers.

8.8-CAHUZAC, MONS. MARTIN (Des.'99) 2.50 Semi-rose type. Mid-season. Perfect solid balls of deep maroon with garnet hues and brilliant lustre. Good erect habit and free bloomer. The "black" peony.

8.6-CHERRY HILL (Thurlow 1915) 5.00 Very deep garnet with a sheen which makes it noticeable in a collection. Stems very long and erect. Fine garden variety.

CLEMENCEAU (Dessert 1920)-_-_-_-_-_-_6.0 Very large full imbricated bloom; carmine slightly shaded amaranth with silvery tints. Very large silvery border. A beautiful very late variety, of which the flowers always open very well. ((Originator's description.)

8.1-COURONNE D'OR (Calot 1873) Semi-rose type. Late mid-season. Immense, full, imbricated ball shaped snow white bloom reflecting golden yellow stamens that show through the petals. These stamens light up the whole flower, making appropriate the name "Crown of Gold." Fragrant

CURIOSITY (Dessert \& Mechin 1886)-----Very attractive, large, globular blooms. Color violet-red, the narrow central petseason.

8.6-CROUSSE, ALBERT (Crousse 1893) --_ 1.00 Immense convex rose-shaped flowers; flesh salmon-pink; one of the most striking.

8.4-CROUSSE, FELIX (1881)--_---Large, anemone ball-shaped bloom, very
brilliant red, ruby flame-colored center: brilliant red, ruby flame-colored center;
one of the best and most popular reds. 


\section{THE SAM CARPENTER GARDENS}

8.9-CROUSSE, MARIE (1892)

Tery large, full, slobular flower of delicate shell-pink with salmon tints. Bomb type. Tall, erect, strong grower and a free bloomer. The flowers are borne on stiff stems and very fragrant. Mid-season. - I most beautiful variety.

CROUSSE, MADAME (Calot 1866) One of the best whites. Pure white, center flecked crimson. Free bloomer. Crown type; mid-season.

7.9-CHEVALIER, SIMONE (Dessert 1902) 1.50 Tery large, globular, compact flower. Pale lilac-rose, tinged salmon-pink, flecked with crimson and bordered with silver. Strong grower and free bloomer. Stiff stem. Fragrant. Early.

CHRISTMAN, WM. F. (Franklin) This beautiful peony was named for our present secretary of the American Peony Society.

CURTIS, FRANKIE (Vories 1924)

The center of this peony is as large as Mons Jules Elie, as compact as a chrysanthemum and sits proudly in a cup of large guard petals. At first glance you would take it to be pure white, but a close inspection will disclose light pink shadings on center petals. It really looks like a large chrysanthemum. The habit of the plant is perfection, strong stems holding bloom upright. Should you purchase only one peony this year, let it be Frankie Curtis. It will satisfy any peony lover in the land and within five years, in my opinion, will be the most sought after peony in America. Season medium early. Introducer's description.)

8.2-CLEVELAND, GROVER (Terry) Fine dark crimson blooms on upright stems of medium height. Good garden effect. Late.

CIMOCHOWSKA, MLLE.

Splendid novelty with enormous large full blooms. Color violet with goldenvellow stamens. Extra. Mid-season.

7.9-D'ARC, JEANNE (Calot 1858) Crown type; mid-season. Soft pink, intermingled with sulphur-white and rose. Center spotted carmine.

7.8-D'HOUR, AUGUSTIN (Calot 1867) -..Bomb type; mid-season. Large showy, well built bloom; deep brilliant red with silvery reflex.

DELACHEI (Delache 1856) One of the most remarkable peonies. A strong grower and free blooming variety. Color deep rich amaranthine purple with a crimson reflex, slightly tipped silver. Rose type; late mid-season.

8.5-DESIRE (Brand 1923) We have been multiplying our stock of this variety as rapidly as possible the past few years, as we had previously sold up our surplus entirely to date. Practically all of the stock of this variety has been sold to visitors who have seen it in bloom in our fields, and because of this we have never been able to get sufficient stock ahead so as to offer it each year through our catalogue. WVe regret at this time that we began to sell stock of this variety so soon, but we now have sufficient stock to offer this splendid pink variety through our catalog. DESIRE is so much in demand and if you wish a root this fall you

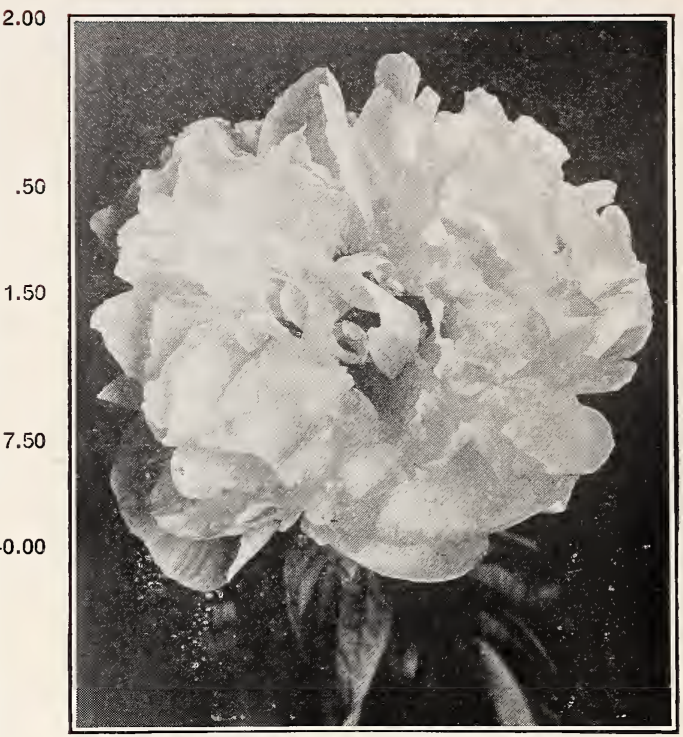

LADI ALIKANDRA DUFF (Description on page 9.)

should place your order early in the season, as ve shall not be able to offer it throughout the entire summer. If you wish a choice pink, you should certainly have this variety. (Introducer's des.)

8.8-DESSERT, LAURA (1913)-_-_-_-_ 7.50 Beautiful, full flowers. Cream-white. guards, center bright canary-yellow. A superb early variety.

8.6-DESSERT, MME. AUGUSTE (1899)_-_- 1.50 Very large flower, semi-rose. Uniform violet-rose, petals slightly flecked crimson. Erect, medium height, free bloomer. Mid-season.

9.4-DESSERT, MME. JULES (1909) 3.50 One of the world's six choicest peonies. Rose type. Mid-season. Color pure white overlaid with a sheen of delicate bluish with a pronounced pink center, intermixed with golden stamens. Very fine.

8.2-DESSERT, MARCELLE (1899) 1.50 Large milk-white flower minutely splashed with lilac, center flecked crimson, very high crown. Very fragrant. Medium habit. Midi-season.

8.2-DESSERT, PIERRE, (1890) Large, medium compact, semi-rose type; dark crimson-purple, silvery tipped; medium habit. One of the earliest dark reds.

9.0-DESSERT, RAOUL (1910)

Extremely large, compact flower of a clear mauve color, shaded carmine-pink and stained silvery-white. Strong grower. Very fragrant; scarce, late midseason.

DESSERT, AUGUST (1920)

Very fine, large, cup shaped red bloom of fine form. One of the best of Dessert's recent introductions. 


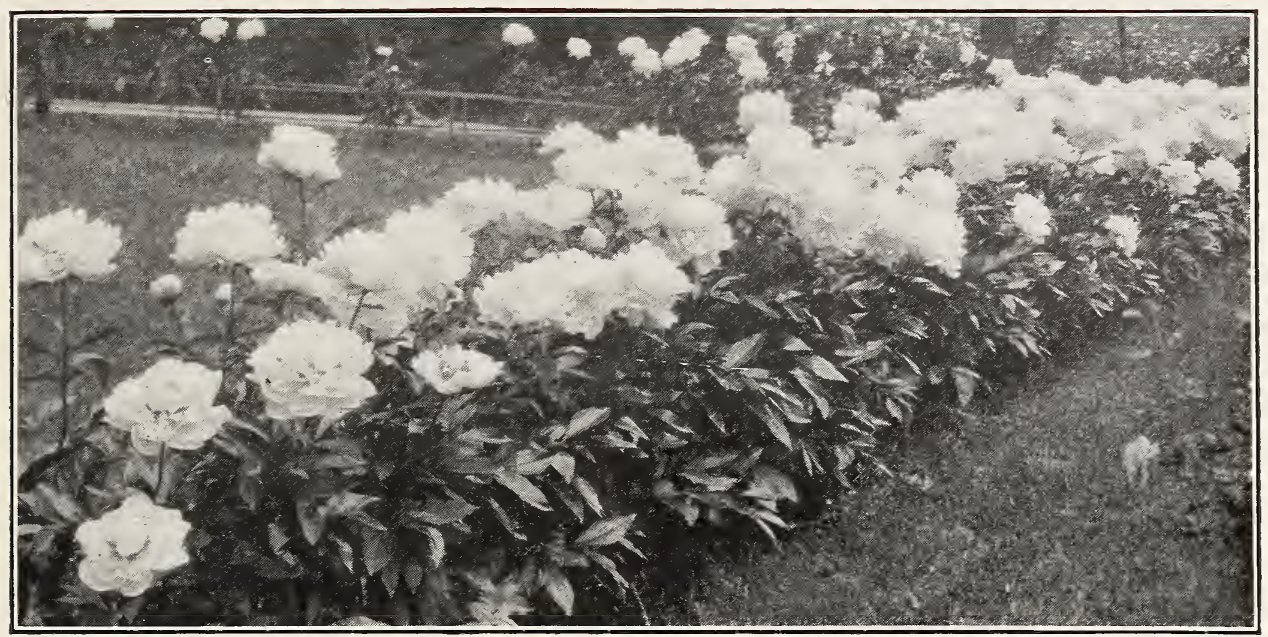

GERMAINE BIGOT

(Description on page six.)

8.4-DEXHEIMER, LORA (Brand 1913) Medium height plants, freely producing very large flaming crimson blooms, singly on stiff stems.

7.5-DE GALHAU, MME. (Crousse 1883) -. Rose type. Late medium large compact bloom. Guards rose-white, center pale lilac-rose. Free bloomer. Fragrant.

7.7-DE VATRY, MME. (Guerin 1863) Large flowers with outer petals flesh color and center petals buff-white with carmine stripes. Fragrant, free blooming and mid-season variety.

7.9-DE VERNEVILLE, MME. Crousse '85) Large, very full, pure white flower with blush center when first opened, fading to pure white, with prominent carmine flecks. Fragrant. Very free bloomer. Excellent for cutting. Mid-season.

8.0-DEROUX, MARIE (Crousse 1881) Rose type; late; large, compact, flat, imbricated bloom; flesh-pink, bordered milk-white; blooms in clusters. Fragrant.

7.9-D'HOUR, MARIE (Calot 83) A fine mid-season pink variety.

7.6-DELICATESSIMA Mid-season, rose type. Fale lilac-rose. Fragrant and tall. Free bloomer.

8.7-DU BOIS, CLAIRE (1886) Rose type; late mid-season. Rich, clear, satiny-pink, with glossy reflex. Very grand flower.

DEMAY, NOEMIE (Calot) Color flesh-rose with silvery reflex. Early.

8.5-DEMAY, OCTAVE (Calot 1867)-_-_.... 1.00 Very large full flower of crown type. Color delicate pink and white. Free bloomer. Dwarf. Fragrant and very lovely. Early.

NANCY DOLMAN (Vories) This is the largest plant with the long-
2.50

7.7-DORCHESTER (Richardson 1870) -.--- 1. Very late, rose type, salmon-pink. Good stems, upright and well shaped.

8.1-DE NEMOURS, DUCHESS (Guerin '56) .50 An early white of crown type. Very beautiful in the half opened stage. Free bloomer and good commercial variety.

D'ORLEANS, DUCHESS (Guerin 1846) - --A popular pink mid-season flower. Free bloomer and good commercial variety.

DUCHESS OF BEDFORD (Kelway).....-. 3.00

\section{8-DUKE OF WELLINGTON (Calot 1859) .75} Late; mid-season; bomb type. Two rows of large snow-white guards around sulphur-white center. Fragrant. Free bloomer. Fine cut flower.

9.1-DUFF, LADY ALEXANDRA (Kelway) 3.00 Lovely French white, when fully opened it is quite white; in the young stage tinted with a very delicate shade of "blush" or" palest pink. The central flower (first to open) is a double flower of rather flattened circular form, and the central petals have a touch of carmine. Very nicely formed. The side flowers ( (freely produced) are semi double saucer shaped form. A grand flower. 


\section{PLANTS THAT GROW AND BLOOM}

9.0-FRANKLIN, MABEL L.(Franklin 1919) 7.50 Outer petals light pink, center petals darker pink. Near the crown of the flower there are intermingled short creamy petals that add greatly to the beauty. Very fragrant.

FLAMBEAU (Crousse 1897) Uniform very dark violet-rose, prominently bordered silvery. Tall, upright grower. Semi-rose type; late.

FRAGRANS (Banks 1805) Compact, full flowers; color solferinored with slight silvery reflex. Bomb type; late.

8.3-FRAICHEUR (Lemoine 1914) Cream-white, shaded pink.

8.4-GUYOT, MME. (Paillet) Large high-built fowers of deep cream or pale yellow with some markings of green. A strong orower and free bloomer. Very desirable. Early mid-season.

7.9-GEISSLER, MME. (Crousse 1880)-_-Large, compact rose type. Well formed glossy pink blooms on strong stems. Massive and imposing.

8.8-GAUDICHAU, MME. (1902)_____- 6.00 Very dark crimson-garnet. Large and globular. Tall and vigorous.

8.5-GALLE, MME. EMILE (Crousse 1881) Large, compact, flat flower of rose type. Deep lilac-white, shading lighter in the center. Strong grower and free bloomer. Late.

8.1-GRAY, ASA (Crousse 1886) Large, full, rose-formed blooms, salmon flesh, flecked with carmine lilac. Tery beautiful.

8.4-GOWDY, CHESTINE (Brand 1913) Cone shaped. Outer petals broad and silvery-pink. Inner petals a cone of broad pink petals, splashed and tipped with crimson. Stems strong, long and slender, bearing single flowers. Tery fragrant.

8.2-GIGANTEA (Calot) (syn. Lam. 1860)_- 1.00 Rose type; early mid-season. Enormous flat flowers of an exquisite bright pink. One of the most beautiful for house decoration.

GINETTE (Dessert 1915)

Large, imbricated cup-shaped flower very soft flesh-pink, shaded salmon, flecked with carmine; fragrance very pleasant; free bloomer in clusters. A very fine variety.

8.4-GERARD, MARGUERITE (Crousse '92) 1.00 Very large full flower of semi-rose type. Color flesh-pink, fading to creamy-white. Strong grower and free bloomer. Very tall. Late.

7.7-GISELLE (Lemoine) Cream-white_-.... 2.00

8.6-GAUDICHAU, MARGUERITE (Millet (1903)

Color white, very highly and irregularly touched carnation, center petals fine cut shell-pink. Semi-double blooms of large size on tall strong stems. Early.

8.2-GISMONDA (Crousse 1895) -..-_-_. 1.00 Globular, flesh colored flowers, delicate rose center; very fragrant. Handsome.

7.9-GUMBAULT, GLOIRE DE CHAS. (Gumbault 1866, introduced by Dessert 1896) 1.00 Extra full globular flowers, deep, fleshy pink color, surrounding narrow petals of

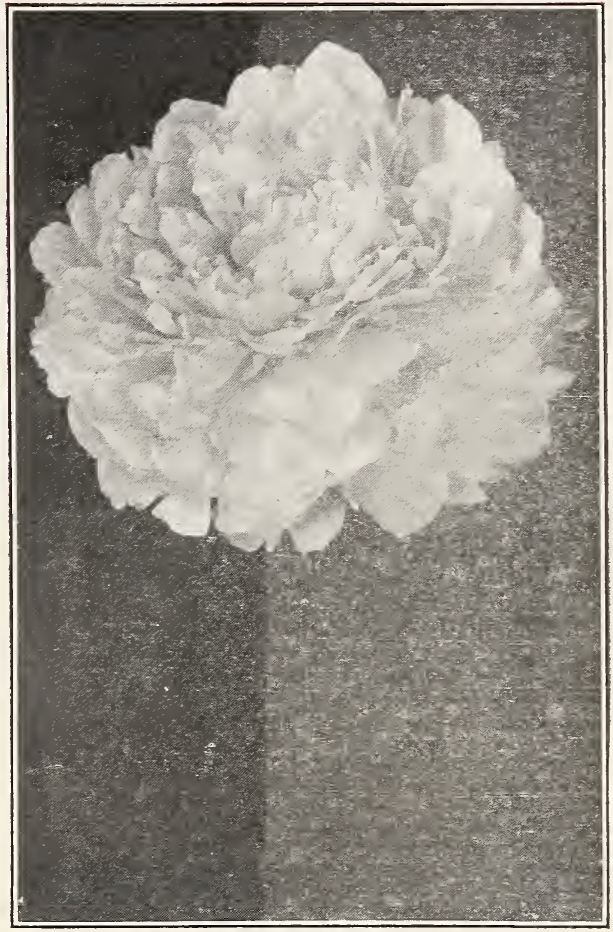

IAA FRANCE

(Description on page 13.$)$

a clear salmon-flesh, shaded apricot, with tuft of very large petals in the center, pink touched carmine. A many colored variety of great keauty.

GLOIRE DE TOURRAINE (Dessert 1908) _ 1.50 Very full flowers without stamens. Lively velvety-crimson with brilliant amaranthine reflex. Rose type, very late.

8.8-GRANDIFLORA (Richardso? 1883) -..- 1.50 Very large flat rose type. Blush-white. Very fragrant, tall, erect, strong grower. Very late. Many consider this the best late light pink.

8.1-GRANDIFLORA NIVEA PLENA (Lemon 1S24) Very early. rose type. Milk-white guards, small pure white collar. Center of various sized petals. 100 years old, but still good.

9.3-GOOD, JOHN M. (Good \& Reese)_-_-- 75.00 Described by the originators as the greatest white peony.

GRETCHEN (G. \& K. 1911) 3.00 Perfectly formed flowers without stamens. Ivory-white, tinted flesh. Strong, erect, dwarf habit.

8.3-GAUDICHAU, JEANNE (Millet 1902) -- 1.50 Large, well formed flowers of delicate pink, fading to a creamy-flesh at tips of petals. Late.

GUMM, LILLIAN (By Gumm) 7.50 Very large, of a beautiful shade of shellpink, deeper in center, blending to white on the outer tips. Strong upright stems and very fragrant. Free bloomer. 
HARUM, DAVID (Blaind)

Large, bright red. Flowers beautifully formed. Guard petals prominent and well expanded. Stems tall, straight and strong. Distinct and profuse bloomer.

HAVEMEYER, KATHARINE (Thur. 1921) 20.00 Large rose type blooms of flesh-pink; suard petals broad and rounded, somewhat rotched at the ends, center retals rarrow and fringed, full high center. Sweet fragrance. Mid-season to late.

7.7-HOLLIS, ADELAIDE (1907)____Crown type; mid-season. Large compact globular form rose white, changing to pure white. Fragrant. Tall, strong free bloomer. Extra fine.

7.8-HILL, E. G. (Lemoine 1906) Very large light Tyrian-rose. Dwarf, 1.50 compact grower. Very showy. Free bloomer. Fragrant, early, mid-season.

7.7-HOLLIS, GEO. (Hollis 1907) Late, rose type. Lilac-white guaras, pale rose-pirk center. Large globular, compact. Fragrant, free blooming. 7.7-HAGEN, H. A. (Fichardson)---_--_-_
Deep rose-pink with a few inconspicuous na:row creamy petals; a fresh, bright color. Very late, but comes out well and one of the good peonies.

8.1-HOLLIS, LUCY E. (Hollis 1907) Rose type; very late. Large, full and double; a fleecy rose-pink. Center shading to pale lilac-rose, flecked scarlet. Fragrant, attractive and good.

9.0-HILL, MILTON (Richardson 1891) Rose type; late. Flowers large, cupped clear soft flesh color. Turns nearly white in full sunlight before fading. One of the finest varieties.

HARDING, ALICE (Isemoine)

This peony on June 8,1922 , was awarded the special prize founded by Mrs. Edward Harding for the best French seedling peony. It is tall with strong stems, very large flowers of the most perfect shape, broad petals of splendid substance, cream white. The demand for this very fine peony has kept ahead of the supply, although it is a vigorous grower and increases fast. There is complaint of diseased roots of this variety, but our stock is clean and healthy. with good roots and big fat eyes. HYATT, ALPHEUS (Richardson)--_-_-_ 3.00
Late rose type. Very large rose-pink of uniform quality. Flower fiat and double. Mrs. Harding recommends this peony.

INSPECTEUR-LAVERGNE (Dessert 1924) 15.00 Fine globular flower, very full, fine vivid crimson, frilled petals in the middle. Beautiful variety with abundant bloom. (Introducer's description.)

8.5-ISOLINE (Lemoine 1916) Cream with yellow tuft.

9.2-JEANNOT (Dessert 1918) Cup-shaped flowers of soft shell-pink. slightly tinted lavender. Salmon-pink lights at base of petais. This variety gives great promise. JOCELYN (Lemoine 1923) -
Full cup-shaped flowers, pale silverypink, edged white, sweet scented.

8.9-JUBILEE (Pleas 1908)--_-_-...-Extremely large flat flowers of ivorywhite, petals long and narrow and arranged loosely, giving a feathery effect. Stems long but weak. Mid-season.
9.0-JUNE DAY (Franklin 1921)

20.00

Light flesh, deepening toward center of flower. Rose type. Some of the central petals slightly edged with lavender. Delicate rose fragrance.

8.3-JACQUIN, MARIE (Verdier) Medium sized flowers of delicate fleshwhite changing to pure white. Petals pointed, and this, with the golden stamens often visible, give a pond-lily effect. A charming and exquisite flower. Midseason.

8.7-KELWAY, JAMES (Kelway) 1.50 Exquisite white with a golden glow at base of petal. Sometimes semi-double. Very tall and strong and very fragrant. Early nid-season.

\section{KELWAY'S BETTY}

Bright cheriy-red, a lovely color; full double; sweetly scented.

9.8-KELWAY'S GLORIOUS (Kelway 1909) 18.00 Buds slightly tinted pink, opening into large blooms of iridescent white. Fragrant. Late mid-season. This is undoubtedly one of the finest peonies. Scarce.

KELWAY'S DAVID

A most beautiful coral-pink; large, handsome flower, quite an acquisition among peonies. Very late.

8.8-KELWAY'S QUEEN (Kelway)

The true variety. Large, globular blooms of fine form and habit. Deep flesh-pink with a few markings of carmine in the center. Fragrant; midseason.

KELWAY'S ROSEMARY (1916)

A very beautiful flower of a delicate soft rosy-pink, with a tuft of lighter petals in the center, surrounded by golden stamens; spicy scented; a very dainty form and most attractive.

7.7-KRELAGE, MONSIEUR (Crousse 1883) 1.50 Semi-rose type; late mid-season. Deep currant or solferino-red with amaranthine center. Large flat flower as big. as a plate. Perfect in outline. Grand in every way.

9.0-KELWAY, PHYLLIS (Kelway) 7.50 Large flowers of flushed pink, yet with the delicate coloring which give a fresh and charming effect. Strong, erect stems. Fragrant; late.

LEVECQUE, MONS. CHAS. (Calot 1872) Sea Shell. One of the grandest of peonies. Color very delicate rose-white, center deeper shading, slight carmine tips. Large, typical rose type. Late midseason.

LYTTLETON, EDITH (Kelway)_ 1.00 Quite an early and free blooming variety of large globular form. Coloring a beautiful deep shell-pink with light satiny tips.

8.3-LEBON, EDMOND (Calot 1864) Rose type. Mid-season. Bright violetrose. Large bloom. Strong short stem. Rather dwarf plant; showy.

LEE, FANNY (Vories)

A very distinct shade of American Beauty red, rich and velvety. Know of nothing like it in the peony world. Plant and stem good, blossom medium to large. It will certainly become a favorite variety with you as it has with us. Mid-season. 
9.2-LOOMIS, GRACE (Saunders 1920) - - 20.00 Tall, strong stems, bearing very full double flowers of clear white. Late. A fine variety.

8.6-LADY EMILY (Pleas 1907)

Rose type; mid-season. Sturdiness of stem and foliage, loveliness of color shading from ivory-rose-pink and primrose; substance of petals waxy and of good quality, resembling the Iris petals in quality and waved effect; the combined coloring with its interspersed golden stamens remind one of the first tints of sunrise. Large loose cup-shaped flower with the side buds adding beauty and distinctiveness to the large central flower.

LADY KATE (Vories)

This is a large, rather flat, rose-formed bloom, of perfect shape, solid color, light pink. It has a distinet color and wonderfully beautiful and will eventually be regarded as highly among the pink peonies as Frankie Curtis is among the whites. The plant is very tall and the stems strong. I pronounce it one of the most beautiful peonies I have ever seen and so will you. One of the latest to bloom. (Introducer's description.)

LADY MAYORESS (Kelway)

Rose guard petals with fimbriated central petals of white; very attractive and distinet.

7.8-LA FAYETTE (Dessert 1904) Large, evenly formed blooms of ricl pink with a silvery reflex. Fragrant and a fine variety. Mid-season.

9.2-LA FEE (Lemoine)

Globular flowers of rose-pink with a silvery light, collar creamy-yellow. Fragrant and early. The available stock of this variety is limited. This beautiful peony justifies its name of "The Fairy." It is one of the most desirable and having a good stock of it ourselves, are naming a very attractive price.

9.0-LA FRANCE (Lemoine 1901)

Enormous, rather flat flowers on strong stems. Soft pink, with lavender lights at base of petals. Late. A very fine variety.

LA FONTAINE (Lemoine 1904)

Bomb type, late mid-season. Large and double, violet-rose; collar lighter; primary petals very wide; center flecked with crimson. A very delicate color. Fragrant.

8.6-LA LORRAINE (Lemoine 1901) Wonderful globular blooms of creamywhite, borne high above the foliage. Some golden stamens are visible, giving a golden light to the apen flowers. Stock very limited. Mid-season to late.

8.5-LA PERLE (Crousse 1886)

Large, cup-shaped flowers, blush-white growing a little darker around the edges. Fragrant, mid-season. One of the best early pink peonies.

8.3-LA ROSIERE (Lemoine 1886)

Large, flat, seni-double flower, creamwhite; beautiful coloring. Very striking. Mid-season.

8.1-LA TENDRESSE (Lemoine 1876)

Large, milk-white flower, sometimes splashed with carmine. Tall, strong, very free bloomer. Fragrant. Midseason.

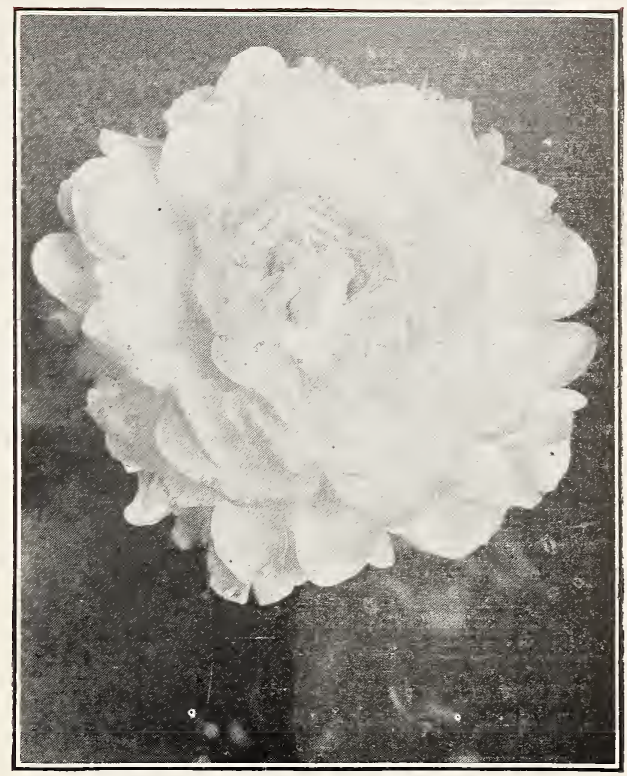

LE CYGNE

7.5-LA TULIPE (Calot 1872)

La"re pointed buds of light pink, beautifully arked with carmine stripes. Flowers light flesh-pink. Very good. Midseaso.?.

LA VER.VE (Kelway) Known as the pink Baroness Schroeder.

3.50

A BRILLIANTE (Cayeaux) 5.00

LANGPORT QUEEN (Kelway)_-_-_-_-_... 6.00 A beautiful rosy-pink color, suffused with pink.

9.9-LE CYGNE (Lemoine 1907)

Rose type; mid-season. This was appropriately named when it was christened "The swan." With good, stiff, rigid stems; foliage the darkest green of all peonies; huds korne in clusters. Very large, perfectly formed flowers with broad imbricated petals. Color creamywhite with a greenish luminosity at the heart; passing to a clear paper-white with age. The globular, compact type of bloom cf this variety makes it easily distinguistable from all others. Unquestionably the fines Has the true June rose frag.ance. $\mathrm{S}$ sored 9.9 receiving the highest score of a?l.

7.3-L'INDISPENSACLE (Origin unknown) 2.00 Rose tyre; late mid-seacon. It is a huge ball of delicate baky-pink. Has by far the most petals of any peony in our collection. On the Pacific slope this is said to stand at the head of all varieties.

L'ESPERANCE (Guerin) - 2.00 Very large lose-pirk: large, fine form and delightfully fragrant; vigorous 1 lant and a profuse bloomer. This is one of the very earliest peonies.

LILLE (Millet 1902)-_-_-_-_-_-_-_-_-_-_. 1.00 Enormous flowers; color cherry-red; crown petals flat with silvery reflex. 
LIBELLULE (Dessert 1922)

Very elegant flower, flesh color, slightly shaded and splashed with carmine, straw and salmon at the base of petals. Very pleasant fragrance.

LIMOSEL (Kelway) Bright, clear, lilac-rose; large, full, double flower; very sweet scented.

8.1-LIVINGSTON (Crousse 1879) Large, full blooms, pretty sofi washed with white, center touched carmine. A choice variety.

9.0-LONGFELLOW (Brand 1917)_-_-_--- 4.50 A bright crimson, probably the most brilliant of all red peonies. Very symmetrical, good grower, stiff stems.

7.6--LORD KITCHENER (Renault)_-_-_-_- 1.50 Very early, rose type, cherry-red.

8.7-LORCH (G. \& K.) Creamy-white with pale rose tints.

8.8-LOVELINESS (Hollis 1907)_-_-...-_-_- 3.00 Flat flowers of immense size; hydrangea pink. Comes in clusters on strong stems. Should be disbudded.

LAURENCE (A new variety from France_- 3.50 Belongs to officianalis family, a fine double red.

L'ORIFLAMME

8.5-LEMOINE, MARIE (Calot 1864) Rose type; very iate. Unđoubtedly Calot's masterpiece. The flowers are enormous and massive, often eight to ten inches across. Color ivory-white with occasional narrow carmine facing on edge of some petals. The gigantic blooms cone late on stout, erect stems standing well above the foliage. A good commercial variety.

7.8-LAGERGREN, MARQUIS C. (Des 1911) 2.00 Brilliant cherry-red with darker shadings. Flowers borne in clusters on stiff, upright stems, which make it an excellent variety for mass planting. Midseason.

8.9-LEMOINE, MADAME EMILE (Lemoine 1899) --_Large, globular, compact, semi-rose type milk-white; medium height, spreading habit, medium bloomer, mid-season. Extra good. Its low price should find a place for it in every garden.

LANSDOWNE, MARCHIONESS OF (Kelway) A beautiful pink

LEWIS, MRS. JOHN M. (Lewis 1920) _-_-- 7.50 Mid-season; rose type. Very dark velvety, oxblood red. Large and compact. Vigorous. Fine cut flower.

LIPTON, SIR THOS. J. (Kelway 1898)_-_-- 1.50 Mid-season; semi-double type; light rosy-carmine with golden stamens appearing in center. Very large.

7.8-MCKELLIP, CHARLES (Brand 1907) _- 1.50 Crown type; mid-season. Open roseshaped and develops into crown type. The irregular rich crimson petals of the center are mingled with gold stamens and surrounded by rows of broad silky guard petals. It has a charm peculiarly its own.

9.2-MCBETH, FLORENCE (SaSS) This is one of the best of the new peonies. The color is a beautiful blush-pink. If you see this peony in bloom you will want it.
8.7-MANN, JAMES R. (Thurlow 1920) - 15.00 Large, deep, rosy-pink, with one or two crimson streaks in the center of the flower and an occasional marking on back of guard petals. Central petals incurved, giving a very graceful effect. Mid-season.

7.4-MASTERPIECE (Kelway 1895)-------- 1.00 A deep, glowing crimson, oftentimes showing some golden stamens. Stems erect and a very fine variety for garden effect. Late.

8.2-MIDSUMMER NIGHT'S DREAM (Pl.) 1.50 Large fiower of rose type. Color ivorywhite with pale yellow center. Distinct and beautiful. Scarce. Late.

8.7-MIGNON (Lemoine 1908) 3.00 Rose type; late. This variety has many of the same good characteristics as the famous variety solange. Very large, perfectly formed flowers with broad, imbricated petals; soft light passing to amber-cream; fragrant; growth very vigorous. Has all the good points.

7.7-MIREILLE (Crousse 1894) -............ Large, conipact, globular, rose type, milk-white, center petals very large and distinctly edged dark crimson. Tall, strong grower. Fragrant. Very late. Good.

MIRIAM (Chase)

Semi-double. Kich pink with lemon-yellow stamens. Strong, free blooming:

7.8-MODELE DE PERFECTION (Crousse 1975

Pink, large compact, cup-shaped, rose. Color flesh-pink marked with bright rose deepening in the center. Good erect habits, Strong stems. Wonderful bloomer. Fragrant. A very distinct and very desirable late variety.

7.8-MODESTE GUERIN (Guerin)

Pink. This is a rose-pink. The flowers are large, compact, and bomb-shaped. It is extra fine in the bud. It is medium early, a free bloomer and very fragrant.

8.6-MONT BLANC (Lemoine 1899) Extremely large flowers of milky-white, very full double. Petals of medium width fringed at tips, giving a feathery appearance. Stems very large and tall. Mid-season.

9.3-MINOT, MRS. CHAS. S. (Minot 1914) - 30.00 Very large flowers, finely formed with broad petals. Guard petals faint shellpink, center of creamy-white with golden lights at base of petals. Late. This is one of the finest of the new peonies, but very scarce. We regard this as one of the three best peonies in our garden last season.

MARCONI (A fine new peony from Holland) 5.00 NIOBE (A beautiful clear carmine-rose)--- 2.00

PAEONIA OFFICINALIS-

These Peonies bloom from one to two weeks earlier than the Chinese varieties and in our latitude bloom in April. Their colors are brilliant and their earliness adds considerable to the Peony flowering season.

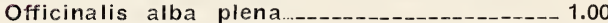
Large convex, double, pure white flower. True variety.

Officinalis rosea plena Pink, double flower. 


\section{PLANTS THAT GROW AND BLOOM}

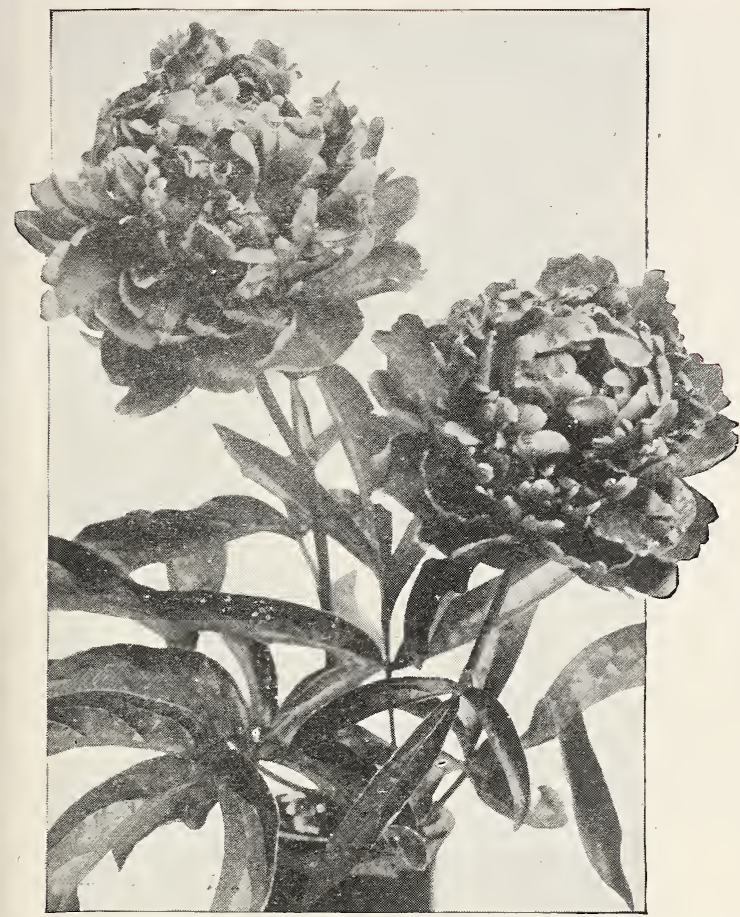

O'THELLO

Officinalis rosea superba Beautiful, large, soft pink, very early.

1.50

Officinalis rubra plena The old deep bright red Peony of the old time garden.

Officinalis tenuifolia flore pleno Double early red, fringed foliage.

1.00

6.7-ORTEGAT, FRANCOIS (Parmentier 1850 ) --crimson with dark shades of amaranth; brilliant golden-yellow anthers; free bloomer; fragrant; striking.

8.5-OPAL (Pleas 1908) Rose type; mid-season. Guards open a dainty pink, quickly changing to French white. The real charm of the flower then unfolds, as it takes the form of a cup or chalice. From the center of this chalice radiates a halo of opalescent pink, giving the effect of a large opal mounted in a setting of satin.

OTHELLO (Lemoine 1916) Rose type; medium size flower; very double; color deep crimson with purplish bronze shading. One of the darkest Peonies in existence.

8.7-PLEAS, ELWOOD (Pleas 1900) Rose type; late mid-season. It never fails to open six to nine huge flowers on each stem, holding them erect during rain and storm. Of largest size, flat, full double, light shell-pink, gradually changing more beautiful and remaining in bloom a long time.
8.4-PFEIFFER, LUETTA (Brand 16) 7.50 Semi-rose type. A very large white with a blush tint, produced in great profusion on long stout stems. Flowers of immense size. Large, pure, glistening white netals interspersed with just enough golden stamens to make it fascinating and heatuliti.

8.4-PASTEUR (Cromsse 1896)-----
l.arge flower of ver delicate large flowe s of very delicate
shell-piuk with sof vellow lights at base of petals. Mid-season.

7.7-PHILOMELE let-rose with yellow center. Develops crown of bright rose, edged crimson. Fragrant, strong and upright, free blooming.

9.4-PRES. WILSON (Thur. '18)-_-_35.00 Soft rose-pink changing to shellpink as flower opens, guard petals sometimes show crimson markings. Center petals very short, somewhat lacinated, gradually increasing in length outward, producing a cup-like effect. Late.

8.6-PRIMEVERE (Lemoine 1907)--- 3.00 Eomb type; mid-season. The name translated means "spring time." Large, full blooms in clusters on tall stems; outer petals sulphurwhite, center petals deep sulphuryellow, often with a tuft of small lingulated petals in the center. Some Peony enthusiasts claim for Primevere the nearest approach to the yellow Peony of any of the Chinensis section.

7.8-QUEEN EMMA (IVild Bros.)

A beautiful mid-season pink. Free blooming.

\section{3-QUEEN VICTORIA}

Mid-season; crown type; white with guards and center fleeced crimson. Cream-white collar. Free flowering and good cut flower variety.

QUEEN WILHELMINA (Krelage 1915)_-_- 5.00 Mid-season. Guard petals rich soft pink with deeper center and salmon tints. Robust upright grower, very fine erect stenis.

8.5-ROUSSEAU, ADOLPHE (D. \& M. 1890) 1,25 Very tall, strong grower, hearing rather loose, sometimes semi-double flowers of deep garnet. Very fine for the garden, where its height and color make it conspicuous. Early mid-season.

7.3-ROUSSEAU, FRANCOIS (Crousse 1909) 2.50 Semi-rose type; early. Large flower of perfect shape. Color lively brilliant velvety-red; almost identical in color with Eugene Bigot, but blooms eight or ten days eariier. An extremely desirable red.

8.1-ROUSSEAU, MLLE. (Crousse 1886) ---- 1.00 Very large, full flower with broad petals. Semi-rose type. Sulphur-white with pinkish flesh colored center. Extra strong stem, medium height, free blcomer. Strong and pleasing fragrance. A gem of the first water.

7.7-REDDICK, H. F. (Brand)
Red. This is one of the best dark reds. It is of medium height, and mid-season. The flowers are large, semi-rose, and brilliant with gold stamens showing a- 


\section{THE SAM CARPENTER GARDENS}

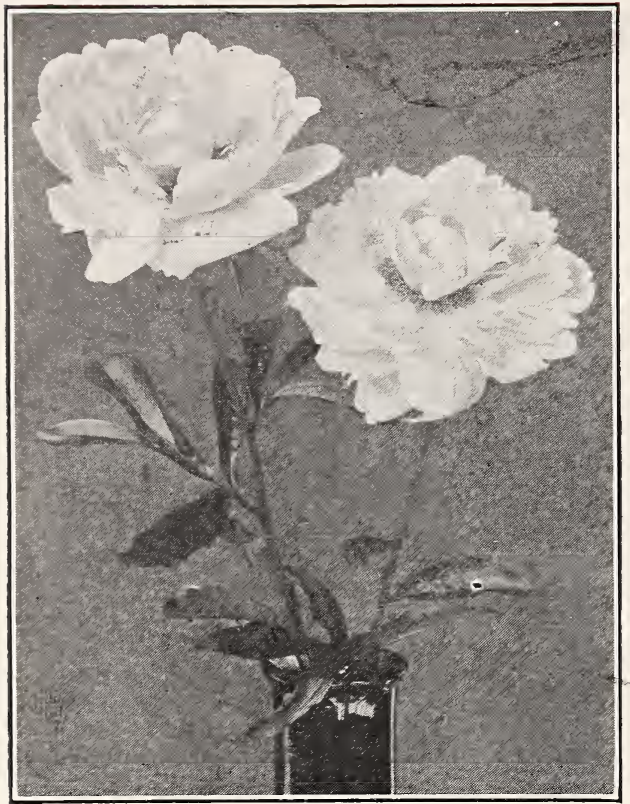

QUEEN WILLHELMENA

(Description on page fifteen.)

mong the petals. Its fine habit of growth, its beautiful blossoms and its profuse blooming hahit, make it a variety which every collector should have.

8.0-RIVOIERE, Madame Benoit (Riv. 1908) 2.00 Very large, beautifully cup-shaled flower; broad outer petals of soft pink; inner petals narrow and of a salmon-pink colo ${ }^{\prime}$ ' with dark salmon at the base.

8.3-RUGGLES, MRS. A. G. (Brand) 3.50 Pink. This flower resembles Therese Mrs. A. G. Ruggles should be disbudded in order to give the best blooms.

9.2-RIVOIRE, PHILLIPPE (Riv, 1911) _- 11.00 Red. A very fine bright crimson. Beautiful in form of flower and splendid in growth of plant. The most fragrant of the red peonies. Very scarce.

RAPHAEL (Mechin 1882) $A$ valuatle early red flowering variety. Color clark purrle-garnet, guards streaked light. Semi-rose type, very early.

8.3-RACHEL (Lemoine) -
Pink. This variety must rot he confused Pinl. This variety must rot he confused originated by Terry. This is a tallgrowing variety, with lo og, straight ste:ns. Trn color is a heautiful clear shade of soft pink with salmon shadings. It comes into bloom mid-seaso?. This is one of the best of the newer Lemoine varieties.

8.7-REINE HORTE.VSE (Calot) Pink. This is a show flower and is usually found in the winning classes. This variety is sometimes sold under the name of President Taft. It is a tallgrowing variety, producing lots of large perfectly formed flowers on long stiff stems. The color is a uniform bydran- gea pink, minutely splashed on a white background. It is also prominently flecked with crimson. It is a truly wonderful flower. We are seldom able to supply the demand.

7.2-RUBRA SUPERBA (Richardson) .75 Red. This variety should be in every collection, as it comes into bloom very late after most of the other reds are gone. The flowers are fragrant, and do not show stamens. It is one of the best keepers of the late varieties. It is shy bloomer, until the plants become well established.

8.8-ROSEFIELD, KARL (Rose 1908) -..-_- 1.50 Very large, globular, compact, semi-rose type; dark crimson; very strong, tall, compact grower and free bloomer: midseason. A very brilliant and striking variety. The best all-round red peony.

8.8-ROSETTE (Dessert 1918) 6.00

Pink. Pretty flower of fine shape like a Captain Christy rose, silvery flesh shading to a salmon at base of petals and flecked crimson on the edges. A splendid variety of erect habit.

8.5-ROSY DAWN (Earr) Vigorous branching habit. Buds of faintly tinted pink, changing to pure white in the open flower. Desirable.

7.6-ROSY DAWN (Pleas 1909) Mid-season; semi-rose. Rose-pink with intermingled golden stamens filling it with the tint of day-break. Clustered. Fragrant; vigorous; good stems.

8.0-RAYMOND, AVIATEUR (Des. 1915) Large, beautiful flower. Very bright cherry-red, shaded garnet and brilliant amaranth. Showy.

RICHARDSON, JENNIE E. (1909) 25.00 Crown type. Broad delicate pink guards cream-white center crown. Large and perfectly formed. Free bloomer. The best Hollis peony.

8.1-RICHARDSON, JOHN (1904) 2.00 Rose type. Very large flat flower, center deep pink, gradually fading lighter towards the tips of the petals. Tall and vigorous. Very fragrant; mid-season.

8.5-RICHARDSON, MAUDE L. (Hollis '04) 2.50 Large flat rose type. Pale lilac-rose center lighter. Fragrant. Late.

8.0-RIVOIERE, MME. JEANNE (Riv. 1908) 3.50 Perfectly shaped flower of a pale rose, with sulphur-white center. Sweetly Perfumed.

SAUNDERS, A. P. (Thurlow 1919)_-_-_-_20.00 Large flesh-white flowers changing to nearly pure white in center; guard petals sometimes marked carmine. Petals very long and curved, giving a magnolia bloom effect, except the center petals, which form a ball until flower is well developed. Late.

7.8-SALWAY, MISS (Kelway 1889)

Crown type. Eariy. Very large, compact, globular flower with high crown. Primary petals white, center lilac-white with collar of sulphur-yellow. Fragrant.

8.3-SALLIER, MNIE. JOANNE (Paillet) Carmine-rose with occasional flecks on guards and center. Semi-double blooms of large size on tall strong stems. Early.

SARCOXIE (Wild Bros.) The Sarcoxie Nurseries have raised a number of peony seedlings, but this one they thought worthy of introduction. It is a brilliant red. 


\section{PLANTS THAT GROW AND BLOOM}

SASS NO. 18

When Sass Bros. pronounce a peony or iris one of the best, you can always depend on it. This is a new red peony which we would rate close to 90 . Still very scarce.

SECOR, NINA (Secor 1922) Mid-season; rose type. Pure white. Full and waxy.

9.0-SCHROEDER, BARONESS (K. 1889) Considered by many the most beautiful peony grown, delicate flesh changing to white, vigorous grower and free bloomer; immense flowers of great substance, with high chalice-shaped center, lasting a long time when cut.

7.7-SISTERS ANNIE (Brand)

Pink. This is a beautiful flower of a deep, flat type, with stamens showing among the petals. The stems are tall and strong. This variety comes into bloom early mid-season. The ground color is a delicate sea-shell pink, heavily suffused with a deep rose. The edges of the petals are fringed.

9.7-SOLANGE (Lemoine) 3.50 Pink. The color of this variety is a deep orange-salmon, or Havana-brown at the heart overlaid with a delicate, tender, rich cream. This variety comes into bloom mid-season, is rose type, and a splendid variety.

SOPS OF WINE (Secor) Large, brilliant wine-red.

9.1-SOUV. DE LOUIS BIGOT (Des. 1918) _- 5.00 Exceptionally large blooms of a very distinct shade of rich salmon-pink with silvery lights. Extra flne. Late. Midseason. Scarce.

SOUV. DE GEN. GALLIENI (Riv.'17) _-.- 10 Late mid-season. Guards lilac-pink, with a soft golden tint. Good size, stout stems. Semi-bomb type.

8.3-SPLENDIDA (Kelway)

Tall, very strong stems bear large globular blooms of flesh-white, slightly tinted lilac. Very fragrant. On account of its strong habit we recommend it as a "landscape variety." Mid-season to late.

8.5-STANDARD BEARER (Hollis 1906) - 7.50 Very high huilt globular blooms with recurved central petals. Uniform color of pale pink. Fragrant. Dwarf but with strong, stiff stems. Early.

8.4-STRASBOURG (G. \& K. 1911) _ Large bloom, 8 inches in diameter. Very compact and perfectly formed. Silvery lilac-rose.

7.6-STANDISH, MILES (Hollis)

Rose type; late mid-season; globular form, compact and full; very rich dark crimson; free bloomer.

7.8-STUART, MARIE (Calot 1856) Large anemone shaped blooms in clusters, broadguard petals, soft pink center petals narrow, soft pink and white.

9.0-SLOCUM, A. M. Beautiful white peony, probably the best of Franklin's seedlings, is very scarce and you will find very few dealers listing it. At our moderate price you should add it to your collection.

6.00

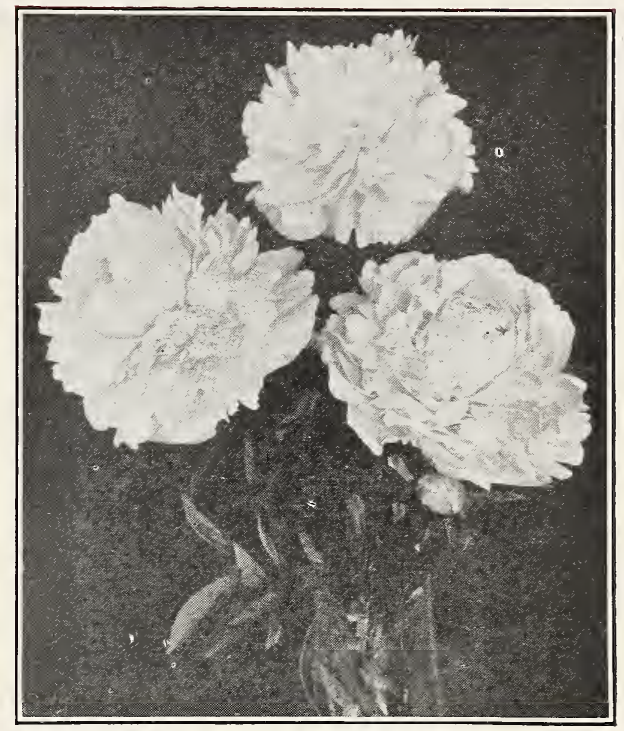

SOLANGE

SYLVIA (Krelage 1916)

7.50

Very large blooms, rather flat, rose-type. Petals very long. Soft rosy-pink with creamy-white base. Late changing to soft rose. Tall.

9.8-THERESE (Dessert)

The color is a delicate, rich, satiny pink. This is generally conceded to be Dessert's hest production. The flowers are of enormous size, and are produced in great quantities on stout stems. This is a peony that is hard to beat.

91-THURLOW, THOS. c. (1919)-_-_-25.00 Salmon-flesh, changing to white. Guard petals hroad and collar of narrower netals or broad petaloids tinted and edged yellow, giving a delicate coloring. The extreme center is made up of short yellow petaloids surrounded by a riro of cup-shaped petals edged yellow. Midseason.

9.4-TOURANGELLE (Dessert 1910) - - 3.50 Pink. Rost type, late mid-season. This is a vigorous grower, bearing large flatshaped flowers, long stems, color pearlywhite overlaid with delicate mauve and with shades of La France rose. Attractive and good.

TOSCANELLI, MME. FRANCOIS (Riv.'11) 3.00 Anemone type. Verv large flower, heantiful flesh-pink shaded soft rose; center dark salmon-rose, very livery colv..

7.8-TRIOMPHE DE L'EXPOSITION DE LILLE (Calot 1865)have a glorious flower that very much resembles Model of Perfection, having the same huge pyramidal effect in form that is seen in but very few va ieries. Large, compact bloom of a fresh $\mathrm{Hy}$ drangea-pink splashed with darker tints of violet-rose, and with white reflex. The guard petals change to nearly white.

TOM THUMB (Terry) 1.50 A dwarf Mons. Jules Elie. 


\section{THE SAM CARPENTER GARDENS}

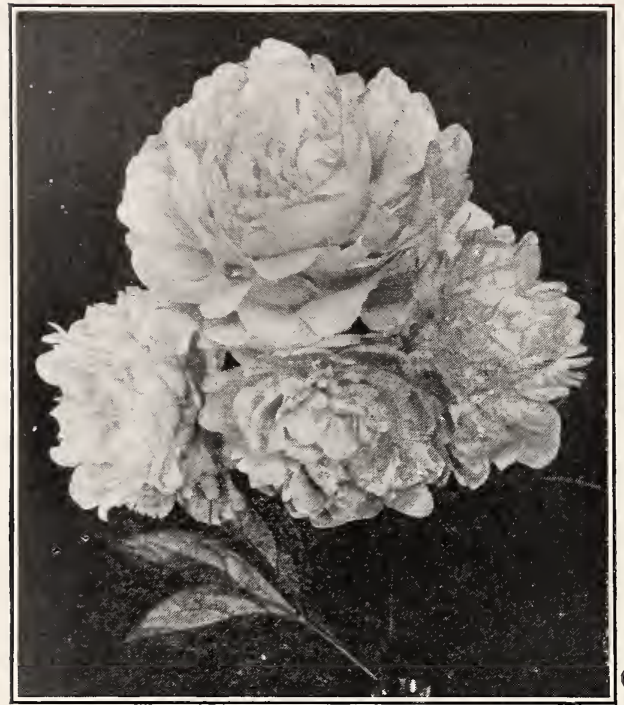

THERESE

Description on preceding page

VORIES, ALEX D.

A very large plant with long, strong stems, on the end of which you will find the largest red blossom I have ever seen. Color, red, American Beauty shade. It is one of the real features with visitors to my garden and will not disappoint. Mid-season.

VORIES, HENRY M

This is a very large, flat bloom, as large as and shaped somewhat like a large La France, every blossom perfect and held erect on a plant of perfect habit. The blossoms are of wonderful substance more so than any with which I am acquainted. The color is distinct. I can only describe it as a solid color, light pink shade, darker to the center. It is quite distinct and you will have to grow it and then perhaps you will be surprised, as well as delighted with its distinctiveness. One of the last to bloom.

VORIES, LAURA

This peony in shape and form resembles Mignon, but is much better. A large flower, strong stems and perfect habit. The color is white with bluish-pink centers with thread-like crimson edge on some of the central petals. The fresh, full blossom is entrancing, the most choice in appearance of all peonies.

VORIES, MARY B.

Somewhat on the order of Laura Vories, except that it is pure white and more open in forn. Makes a grand plant with fine, strong stems. One of the last to bloom and one of the hest whites in existence. You can make no mistake in placing this in your collection.
VAN DER TAK, DR. H. (1916)

This variety shows up better each season and under the very unfavorable blooming conditions this year, it was remarkably beautiful. Early mid-season. Semi-rose type. Wine red sometimes showing a few stamens with a pronounced shade of crimson toward the center. while the edges of the petals are shaded somewhat lighter. A very vigorous grower with stiff erect stems. Opens freely and for a red is a profuse bloomer.

7.5-VALLIANT, MARECHAL (Calot 1864) Red. Extra large, compact, globular rose type. Dark mauve rose. Very tall plant, with coarse stem which fails to support the heavy bloom. Very late. A good variety.

8.3-VENUS (Kelway) Mid-season; crown type. Pale hydrangea-pink with lighter collar. Fragrant. Very large and tall. Free flowering.

8.3-VERDIER, EUGENE (Calot 1964) 1.50 Late, rose type. Large double flowerc of delicate hydrangea-pink, outer guard petals lilac-ivhite. Free bloomer, Strong stems.

8.6-VERDIER, EUGENIE (Calot 1864) -.-- 1.00 Early, semi-rose type. Do not confuse this name with Eugene Verdier A strong, healthy grower with enormous pink blooms on three or four foot stems. Very desirable.

WAR (Kelway 1916)

Large flower of a dazzling crimson-scarlet, showing golden stamens in center, giving an exceedingly rich effect.

7.0-WASHINGTON, GEORGE (Hollis 1904) Large, flat, loose, semi-rose type; uniform, dark crimson; medium height, erect; mid-season.

9.1-WILLARD, FRANCIS (Brand) $-2.50$ White. This variety is listed among the World's 22 Most Beautiful Peonies. It is a perfectly-formed flower. The petals are of varying sizes, forming a very large rounding flower, often having a raised, cup-shaped center inclosing golden stamens. It opens an exquisite blush-white, with an occasional carmine touch, changing on the lawn to pure white. Although delicate in appearance it is of good substance and an excellent cut flower. Altogether. it is a wonderful combination of strength and delicacy. It is found among the winning classes in every show room.

7.9-WOLAVER, HELEN (Brand 1918) -..-- 2.00 Sea-shell pink, splashed with a darker pink. Very late.

VAN LEEUWEN, MR. L. (1916)

Semi-rose type. Late mid-season. Large beautiful flowers, graceful loose formation and delightful curved petals. While classed as a semi-rose type, the flower is quite full, presenting a very charming appearance. Color is deep tyrianrose, almost carmine, of a bright even uniform color with delicate reflex. Texture is superb, of splendid, lasting quality, making it invaluable for cut flowers and a most attractive sort for color in the garden. Growth is decidedly vigorous and robust with erect tall stems. 


\section{SINGLE and JAPANESE} Peonies

As they become better known, this class of Peonies has become more popular and go garden is complete that does not contain at least a few of them. They are very fine bloomers, especially fine for garden and landscape effects-a mass of large dainty flowers of delicate tints and fine golden stamens. Very artistic for cut flowers, as they bloom in clusters on stiff, upright stems, presenting a pleasing mass of color.

AKALU

Japanese type; large bright carmine-red: single flower, tuft of centrai filamentous petals saffronvellow, striped carmine, extra.

8.4-ALBIFLORA, THE BRIDE (Syn. La Fiance) (Dessert 1902) _-_--- 1.50 Also Snowflake (Kelway). Very large; pure white. Tall, vigorous grower, free bloomer, very early.. Finest single white. Distinct from the primitive species Albiflora, being the taller grower, much larger, fine flower. Identical with the single white sent out by Dessert as LaFiancee. However, to retain the name The Bride, to avoid confusion with the double white variety originated by Lemoine in 1898.

9.2-AMA-NO-SODE (Jap.)

Exceptionally large flower, petals bright rose-pink with lighter tints and a mass of stamens. Very scarce. A purple-red single, shaded violet.

CORALLINA (British species) Purple-red; single flowered; the seed pods containing black and coral-red seeds, are very effective. Early flowering.

8.5-DESSERT, MARGUERITE (Single '13) 5. OO Very large flower. Pure white, splashed with crimson. Central tuft of golden stamens. Very attractive.

EGLANTINE (Dessert 1913) White, tinted carmine, with golden anthers in the center. Like a giant wild Rose.

EASTERN BROCADE (Kelway) White flushed pink; a "single" flower rather "cactus" in shape.

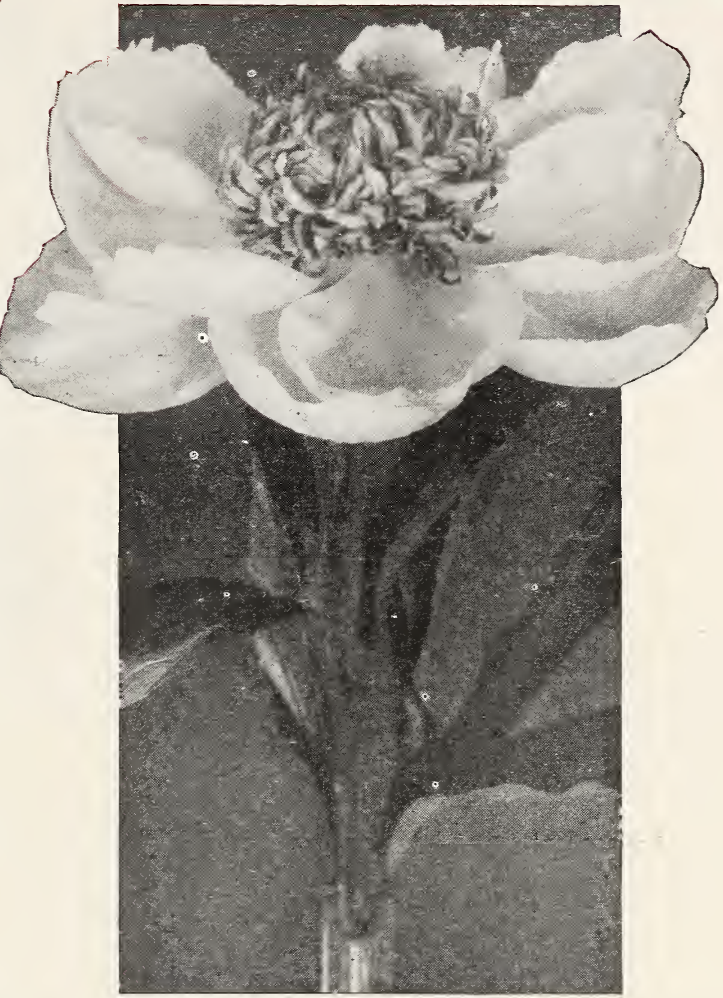

E. ST. HILL (Single 1916) One of the largest single peonies, many flowers measuring $81 / 2$ inches across. Deep rose-pink, shaded white at the edges, with yellow centre. The well formed flowers are borne on strong stems well above the foliage.

7.9-FUJI-NO-MINE Very large and free blooming; white with rich cream certer.

9.2-FUYAJO

Velvety, ark maroon, black guard petals; center petaloids striped crimson and white. Coarsely crinkled foliage.

FULL MOON (Kelway) White outer petals with creamy-yellow narrow inner petals.

8.5-GAUTHIER, MADELINE (Single 1908) 3.00 ( (Dessert) Flesh color, silver reflex.

GOLD MINE (Hollis-Japanese 1907)__._._ 3.50 Flat, loose, medium size. Guard petals tyrian-rose, center same as guards, tipped golden-yellow. Medium tall, erect, mid-season variety of good habit.

HELEN (Thurlow 1922) One of the finest single pink peonies. Double row of broad rounded petals of deep shell-pink and mass of golden stamens, on tall erect stems. 


\section{THE SAM CARPENTER GARDENS}

HER GRACE

Another of Kelway's lovely new Imperial peonies. Delicate light pink with yellow petaloids. A grand flower.

8.2-INNOCENCE (Hollis, Jap. 1904) Pale pink guard with golden center. Fragrant: mid-season.

9.3-ISANI GIDUI Pure white with sulphur shades. Bright golden stamenoids. Tall and vigorous. Large. One of the very best Japs.

JACQUELINE (Single) Pure glossy white, with narrow light yellow petals in center.

KELWAY'S WILD ROSE (Single) White speckled all over with pink; delicate unique and most charming.

KING ALBERT (Kelway 1916) Enormous flowers, 8 to 9 inches across; rosy-violet or solferino color; extraordinarily fine.

8.6-KING OF ENGLAND (Kelway)A rich shade of carmine, the long stamens self color edged golden. Tall, strong grower and free bloomer. A brilliant variety. We believe our stock to be the true strain.

KUGARI-KUN (Barr)

This is one of Barr's best Japs. Scarce. KAME-NO-KEGOROMA (Jap.) --_-...--_-_ 5.00 (Syn: Flamboyant) Rose, central filamental petals yellow.

8.4-L'ETINCELANTE (Dessert)

Large flowers and broad petals of brilliant carmine with a silvery border. Stems erect and vigorous.

LOTUS (Single)

Very early and continuous bloomer. Cut blooms keep 10 days in water. Loose cluster of 3 to 5 flowers on tall upright stems. Long warm pink petals, small center bright gold.

MAETERLINCK, MAURICE (Kelway) -..-- 3.50 Large purple-crimson with golden center. Very late flowering.

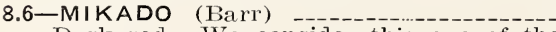

Dark red. We consider this one of the best of the red Japanese peonies. This variety was first exhibited in America by the Japanese government in its exhibit at the Chicago World's Fair in 1893 . This is a large cup-shaped flower with a single row of wide dark crimson petals, encircling a filigree cushion of golden petaloids; crimson edged and golden tipped.

MISTRAL (Dessert)

MISTRAL (Dessert) of great beauty. 1.50 Bright scarlet-crimson, the brightest of all single peonies. Extra fine.

8.1-MARIE (Calot 1868)

Well formed, compact flowers of white with a faint tinge of canary-yellow. Very tall, stiff stems, and very late.

8.0-THE MOOR (Barr) Medium size. Purple-garnet. Medium tall, vigorous, free bloomer. Rich color, almost as dark as Monsieur Martin Cahuzac. Early.

NELLIE (Kelway)

Blush-pink. One of the finest varieties of this color; very strong and tall; early flowering; the largest flower of all single flowered peonies.
7.50 5.00 2.50

$$
\begin{gathered}
\text { SHOGUN (Jap.) - } \\
\text { A beautiful garnet-red Jap. }
\end{gathered}
$$

\section{0-SOME GANOKO} Late, very dark red with a satiny reflex, flower and a vigorous bloomer.

9.4-TAMATBAKO Bright China-pink. Bright yellow petaloids. Very large. Very scarce and in great demand.

TOKIO Clear pink with large center of golden petaloids. Very large. One of the finest pink Japs.

\section{5-WHITLEYI MAJOR}

Fine foliage, heavy and dark green. Very profuse bloomer of bluish-white flowers with golden hearts, on strong stems.

9.1-WHITE SWAN (Fleas 1913)-_-_-_-_-6.00 Pure white, large, waxy petals around a center cushion of golden stamens. Faint green tinge in center. Large and clustered.

8.5-WHITE LADY (Kelway 1900)_-_-_ 9.00 Another beautiful single white peony, like a water lily in form.

8.0-WILBUR WRIGHT (Kelway) Deep maroon or chocolate, flowers well above the foliage; of good habit; it is splendid for cutting from, also makes a fine "Specimen Plant." 


\section{Good Things to Look Forward To}

We have ten each of the following. Japanese Tree Peonies growing in our gardens, but under import regulations cannot offer them for sale for some time. What's in a name?

AHASHIGATI. ASAHT-MINATO. AKA-DAIKAGURA. BENI KIRIN. BENI-KAMADA. DAI-KAGURA. FUGI-NOMINE. FUGI-NAIMORI. FUGO-KO.

GASHOZAKUM. HANA-KUROBE. HIRYO.

HAKU-BAURIN. HANA-NO-TSUKASA. HANUN-SHUDEN. HANA-NO-NISHIKI. HAKU-RAKU-TEN. HANAGURUMA. HADE-SUGATA. KAGURA JISHI.
KABA GASONE. KAKURIU NISHIKA. KIGYAKU.

KASANE JISHI. KA-KIRIN. KIN-FUKUPIN. KAMADA-FUJI. KASUMI-NO-MORI. KIKU-BOTAN. LUMMEIKAI. MIKASA-YAMA. MISU KAGE. MICHISHIBA. NIPPON-KO. AKINI JISHI. OSAKASUKI. RENI-TSUKASA. RURIBAU. RAIDEN.

\author{
SHIN AKEBONO. \\ SOWA-NO-TAKI. \\ SAIGYO-ZAKURU. \\ SHIRO-KAGURA. \\ SHIN-ABAKIN. \\ SHERSHINKA. \\ SUISHOHAKU. \\ SEIDEI. \\ SHUCKUKA. \\ TENGAKUKO. \\ TANO FUYO. \\ TSUKASA JISHI. \\ TSUZURE-NISHIKI. \\ TARNA-USAGE. \\ TWATO-KAGAMI. \\ UKARE JISHI. \\ YOCHIYO JISHI. \\ YUKI-DORO. \\ YAYANO-HAMORE.
}

\section{French Tree Peonies}

BARONNE D' ALES.

BIJOU DE CHUSAN.

CAROLINA D' ITALIE. COMPTESSE DE TUDOR.

DELAVAYI AUGUSTILOBA. FRAGRANS MAXIMA PLENA. JEANNE D' ARC.

JULES PIRLOT.
LACTEA.

LAMBERTINAE.

LOUISE MANCHELET.

L'ESPERANCE.

LA LORRAINE.

LUTEA SUPERBA.

MME. LOUISE HENRY.

MME. STUART LOW.
MARQUIS DE CLAPIERS.

REINE ELIZABETH.

ROBERT FORTUNE.

SOUV. DE MAXINE CORNU.

SURPRISE.

SOUV. DE DUCHER.

TRIOMPH DE VANDERMARL

THE JAPANESE HYBRIDIZERS have also sent us ten each of the following herbaceous Peonies, which they recommend as very fine. We are anxious to see them bloom this spring, when we can give you more definite information as to their value. The descriptions are from the Japanese grower.

KYOKUSHO-Crimson, round petals, edged yellow, full double.

MIYAHARU-Pure white, striped with pale pink, large full double.

YOSO-OI--Rose, beautiful yellow anthers, full double.

KWA-KO-YEN-Pale rose, edged pink, full double.

KAKEORI-NISHIKI-White with pink shades. Full double.

YOCKINO-IKE-White at beginning, pink at bottom, handsome double.

SHAKKO-Dark crimson, beautiful anthers, double.

FUJI-NO-YUKI - Snowy-white, tusseld anthers, double.
SHU-MO-OI-Satiny-red with cluster of petaloids; double.

KOCHINOMAI-Dark crimson, fall flowering, double.

AKEBONO-Pale pink, good formed flower. Double.

DOISECHAKU-White with pink shades with petaloids; double.

MOI-SHOJO-Satiny dark scarlet, round petals, double.

UMYA-SHISHI-Dark scarlet with golden anthers, double.

TOI-KASAN-Dark scarlet, fall flowering, double.

SHIRAGA-JISH!-Pure white with petaloids double. 


\section{Finlint J J erounte Slratylur was born at Ashtabula, Ohio, in 1843. For} salesman with the Meriden Cutlery Company at Meriden, Connecticut, and in 1898, on account of ill health, he came to Auburndale, Massachusetts, purchased twenty acres of land, and built a home.

He first became interested in growing Gladioli, but when he found that a frost-proof building would be necessary for storing the bulbs in winter and money being not very plentiful at this time, he abandoned the idea.

In 1900 he purchased 200 Peony plants from various American growers, and set out on his Peony career. A year or two later he began to import rare varieties from the best English and French growers, and from the seeds of these imported varieties he originated the Shaylor Peonies.

In 1911 Mr. Shayior received the Massachusetts Horticultural Society's Gold Medal for high culture and correct nomenclature.

He was the first grower in America to receive it. In 1916 Georgiana Shaylor was exhibited for the first time and received

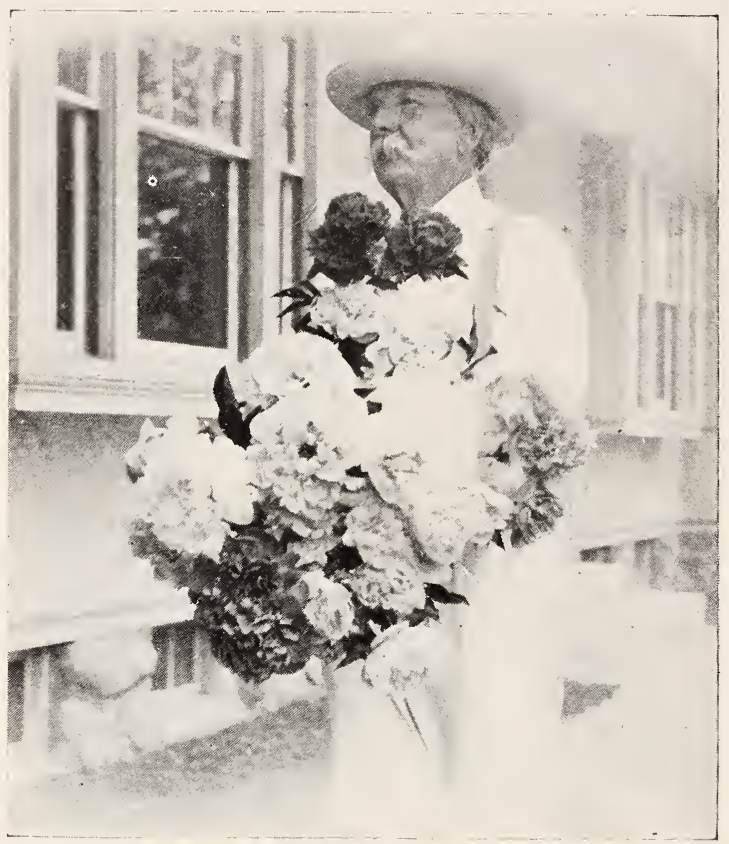

EGBERT JEROME SHAYLOR. a first class certificate of merit.

Since then about forty Shaylor varieties have been introduced. Mr. Shaylor really developed a genius for originating new varieties. He led the way for all the growers in America, and they are inciebted to him for his advanced work.

The above brief biography of Mr. E. J. Shaylor, who died last October, was written for us by Mr. J. H. Allison, of Auburndale, Mass., who was associated with Mr. Shaylor in the Peony business these last few years, and who will continue the carrying on of Mr. Shaylor's Peony Gardens.

Personally, we have always regarded Mr. Shaylor as the greatest peony originator, and authority in America, being only surpassed by Lemoine, and Dessert, of France.

We never had the pleasure of meeting Mr. Shaylor, but have had considerable correspondence with him and have found him most interesting, kindly and helpful, with very decided views on most subjects and not afraid to state them forcibly.

Mr. Shaylor ascribed his success in originating such fine peonies to the fact that he used seed only from the best varieties, and he was the pioneer in this and other growers learned the "secret" from him. Mr. Shaylor wrote us "There is no secret in my work; just the best kind of common sense. Don't expect to raise thoroughbreds from common stock. It may be done, but it will only be a streak of luck." 
Had Mr. Shaylor possessed the salesmanship of some of the bigger growers, he would have surpassed them all.

His peonies are all fine, and too little known, and we are giving them a place to themselves in this catalogue with the advice to our friends to plant these Shaylor peonies if you want something absolutely superior.

We would rate Rose Shaylor, and Mrs. Edward Harding 100, and at least six others we would rate above 90 .

\section{Shaylor's Superb Double Peonies}

8.9-AUREOLIN

This fine Jap. peony is in very few collections and is one of the most beautiful, pink with strong yellow center.

\section{DORIS}

This is one of the finest pink peonies and very scarce. It will be in same class with Therese and Walter Faxon when better known.

EMERY, MISS

This is also a rare peony and at the very moderate price deserves a place in every fine collection. Salmon-pink.

FORCE, MRS. SHAYLOR

We have been informed that this beautiful peony was one of Mr. Shaylor's favorites. It is a large, compact bloom of globular form of ivory-white, a few narrow yellow edged petals in collar and sometimes slight flecks of crimson in center. Very fragrant; mid-season.

CLOUGH, MRS. M. P

A large flower of salmon-pink.

9.1-FEWKES, SECRETARY (1916) Very large flowers with broad rounded petals of great substance. Creamy-white with lighter centers. Tall, strong stems and a vigorous grower; mid-season.

GILBERT, MRS. CHAS. (1916) 6.50

A large loose flower with exact color of Therese. Very fine.

9.3-HARDING, MRS. EDWARD (1918)_-_25.00 Large pure white flower of fine quality. Petals are set close together without over-crowding. Mid-season to late. This is one of the world's best.

8.8-LOCKWOOD, WILTON (1915)_-_-_10.00 This peony is not sufficiently appreciated, and deserves a higher rating. A tall, strong grower, producing large flat flowers of deep pink with pronounced crimson markings on some petals; midseason.

MCCLELLAND, WILL

Mr. Shaylor listed this peony as TVill McLellan, but we have a letter from the man for whom it was named stating the name was not correct. Another exquisite bloom of tyrian-rose color found in very few lists, but better than 90 per cent of those they. do list.

9.6-SHAYLOR, CORNELIA ('17) 15.00 $A$ full well formed flower of pyramidal shape. Guard petals and collar of a faint pink, softening to white and deeper shell-pink center. An extra good variety. Late.

8.5-SHAYLOR'S DREAM A very delicate flesh-white.

8.9-SHAYLOR, EUNICE (1919) 6.00 Another little known but exquisite variety. Globular blooms of ivory-white, outer petals slightly flushed pink. Some stamens present give golden light over the flower. Mid-season.

8.6-SHAYLOR, FRANCES (1915) 5.00 Another charming flower belonging in the 90 class and listed in few catalogues. Globular flowers of iridescent white petals interspersed with incurved yellow stamenoids. Tery distinct, dwarf plant. Midseason.

8.9-SHAYLOR, Georgiana ('08) -- 5.00 This was one of Mr. Shaylor's first supreme achievements, and he always regarded it as one of his best. Exceptionally large, flat flowers of pale 


\section{THE SAM CARPENTER GARDENS}

rose-pink with an occasional crimson fleck. Dwarf but steady habit. Midseason to late. A grand peony.

8.5-SHAYLOR, JESSIE (1916) Large rather flat flowers of a delicate 5.00 shade of deep cream with a reflexed light, much like that of a tea rose. Fragrant; mid-season. White with yellow center. Very scarce.

SHAYLOR, LUELLA (1917)

A very fine white with cream center. Mid-season.

9.0-SHAYLOR, MARY WOODEURY ('16) 12.00 Another wonderful peony, close to the top and very scarce. Guard petals fresh shell-pink, center creamy-yellow with golden lights at base of petals. Plants dwarf with upright stems. Mid-season.

SHAYLOR, MRS. E. J. (1921)-_-_-_-20.00 Very large flower of delicate pink, petals broad and well rounded. Rather loosely built flower, but full. Late, midseason.
SHAYLOR, MINNIE (1923)

One of Mr. Shaylor's latest and best introductions and belongs in every fine collection. Medium height and short upright stems, being large flower of fleshpink, resembling Mrs, A. Duff. Midseason.

SHAYLOR, NELL (1920) $-10.00$ A dwarf growing plant producing large shell-pink flowers. Odor like a tea rose.

9.1--SHAYLOR, ROSE (1920)-_-_-_-_0.00 We consider this among the three or four best peonies in the world. It has well formed flowers with somewhat loosely arranged petals of delicate flushed white. Pleasant fragrance. Erect strong grower; mid-season.

8.8-TURNER, WM. F. (1916)-_- 5.00 Very dark red or garnet. Tall, strong grower and gives a fine spot of color in the garden. Darker than Cherry Hill, and recommended by the Peony and Iris Growers' Association as one of the best reds.

\section{Shaylor's Superior Single Peonies}

\section{5-A LMA (1916)}

A beautiful Jap. with pale pink petals inclosing a mass of incurved yellow petaloids.

ALLISON, DOROTHY Very îresh pink. 3.00

8.3-ALLISON, MARJORIE (1916)_-_-_-_ 5.00 Early. A strong satiny-white single.

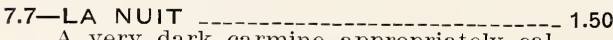
A very dark carmine appropriately called "The Night." Early.

5.00
8.6-LE JOUR

A large pure white; good substance. Very fine.

L'INNOCENCE

Satiny-white.

LE NOIR dark crimson.

SAYLES, DEBORAH A very fine shell-pink.

WALKER, DEBORAH

A delicate pearl-pink.

\section{PEONY COLLECTIONS}

We are listing here a few collections of Peonies at reduced prices.

FESTIVA MAXIMA-white

MONS. JULES ELIE-Pink

KARL ROSEFIELD-Red

Three of the best for $\$ .50$ $-\$ 2.50$

THE CONNOISSEUR'S COLLECTION:

CORNELIA SHAYLOR

LA FEE

$\$ 15.00$

UVENIR DE LOUIS BIGOT

QUEFN WILHELMINA

8.00

5.00

5.00

38.00

Five Real Aristocrats for

$\$ 25.00$

THE BEST JAPS IN EACH COLOR:

9.2-AMA-NO-SODE-Pink

9.2-FUYAJO-Red

$\$ 10.00$

7.50

9.0-WHITE LADY-White -

The Peony and Iris Growers' Association of America selected the 50 best peonies to recommend to new growers. The 15 listed below are all from that list:

8.9-MME. EMILE LEMOINE-_-_-_-_-_\$1.50

9.0-BARONESS SCHROEDER .......-.- 1.50

8.2-MARIE JACQUIN _-_-_-_-_-_-_-_-_ 1.50

9.3-FESTIVA MAXIMA _-_-_-_._-_.-. 50

COURONNE D' OR-

8.5-MARIE LEMOINE -

8.8-GRANDIFLORA _-_..._-_-_-_-_-_-_. 2.00

9.0-SARAH BERNHARDT - -

EDULUS SUPERBA -

8.6-ALBERT CROUSSE -

9.1-REINE HORTENSE --_-_-

8.8-KARL ROSEFIELD _-_. 1.50

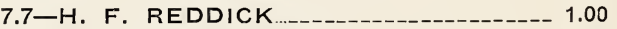

8.5-ADOLPH ROUSSEAU _-_._-_._- 1.25

9.2-MONS. JULES ELIE

3 highest rating Japs and single for $--\$ 20.00$ 


\section{PLANTS THAT GROW AND BLOOM}

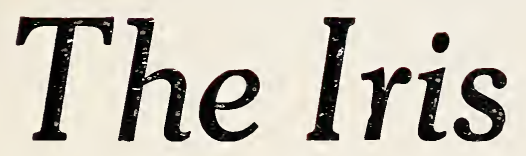

WE ARE all more or less wise in our own conceit, and although we have grown and loved flowers for more than a quarter of a century, it is only the past four years that we have become acquainted with and enamoured with the Iris. Before that we were one of the large number of "unbelievers" who did not care for the Iris, or "Blue Flags," as they are commonly called. Since our conversion it has been our privilege and delight to bring many others up to the "mourner's bench" to have the scales removed from their eyes, so they could visualize and worship at the shrine of this most beautiful flower.

The Iris has been voted by the members of The Garden Club of America as the most popular perennial, having more admirers than the Peony, rose, phlox, delphinium, all gloriously beautiful, too, with many distinguished advocates singing their praises, but falling short of the "rainbow flower" in the number of enthusiastic devotees.

The old fashioned flags of grandmother's garden, beautiful as they were and still are, were all so common, and as familiarity breeds contempt, so they had no attraction for us; but behold the wealth of splendid products of the modern plant breeder, who has given us such variety of form, color, size and time of bloom, they surpass the rarest orchids in delicacy, and in colors from pure white and rich yellows, thru tones of blue and lavender to the deepest purple and rich red browns, and almost pure reds and blues.

A modern Iris garden is a veritable fairyland, and he must be hardened indeed who does not yield to its charm.

The ardent flower lover wants to linger for days, but the casual visitor, like the tourist who must see all the treasures of the Louvre, or of the British Museum, or The Metropolitan Museum of Art, in a day, gets surfeited and tired before he can contemplate all the splendid things spread before his eyes.

When visiting these famous galleries, the wise tourist, with a real appreciation of the best, searches his Baedeker, and seeks out those "double starred" and passes up with a casual glance only, many beautiful things not so famous, so in a few hours' visit to a large garden showing a thousand varieties, seek out the best things, and if you can come another day, seek out some more. Hit the high spots, as it were. Have yourt pencil and note book with you and write your own opinions and descriptions of those that appeal to you.

The Iris is classified into many types, as well as unusual varieties of each type.

First to bloom are the dwarfs, or pumila type, and some of these start blooming here in March, even pushing their delicate blooms up through the melting snow.

In the Tall Bearded Iris, we have the type most numerous, and furnishing the major part of most collections. It is the perfect perennial, requiring no special care or coddling.

Plant in full sunshine in ordinary soil where drainage is good, and it will thrive for years and give a wealth of bloom. Most of them are hardy and the foliage is quite ornamental, even before and after the blooming season. A little bonemeal is beneficial but fresh stable manure should always be avoided.

We use old plaster in our beds, when we can get it, as the lime and gypsum therein is beneficial. In planting, barely cover the rhizomes or fleshy portion of the roots.

We usually mound up the beds about six inches, to give good surface drainage, which is essential to success. If the roots are freshly dug, the same roots attached to the rhizome will take hold and grow, but if shipped long distances and dry, new roots will have to form. 
We have successfully planted and transplanted them at all times when the ground is not frozen, but the best time is after the blooming season in May or June. Planted at this time they well make good growth and bloom the next spring, and the second season the clumps will be at their best.

Keep the beds free from weeds and grass and the added bloom will well repay you. The blooming season is greatly prolonged by the Japanese type, or Iris Kaempferi, a sort in which the falls are large and spread horizontally rather than drooping. Usually there are three, the normal, but in some there are three more, and these are called doubles. Nothing in the garden surpasses the Japanese Iris for brilliance and showy beauty. Planted in large masses, they create a striking display, greatly admired by all who see them.

The Japanese Irises love moisture, and should be planted deeper than the bearded species, and no lime should be used around the roots.

There are also the Spanish and Dutch Irises, which grow from bulbs, and are very showy in the border, and are also very popular with the florists for forcing in the greenhouse.

Another group, overlapping the Bearded Iris and blooming before the Japanese is known as the Siberian Iris. These form a dense clump of narrow grass-like foliage, from which rise many slender stems three to four feet high, crowned with five or six delicate flowers.

Perry's Blue, with sky-blue standards and broad falls of a wonderful shade of old China-blue, is one of the best known Siberian varieties.

At the recent meeting of the Commercial Peony and Iris Growers of America in Chicago, the following varieties of Irises, all belonging to the Tall Bearded type, were selected as the best, regardless of price, to recommend to new growers:

AFTERGLOW
ALCAZAR
AMBASSADEUR
APHRODITE
ASIA
BALLERINE
B. Y. MORRISON
CECILE MINTURN
CARDINAL
DREAM
FAIRY
PARC DE NEULLY
GEORGIA

ISOLENE
JACQUESIANA
LORD OF JUNE
LOHENGRIN
MAGNIFICA
MA MIE
MID WEST
MILDRED PRESBY
MORNING SPLENDOUR
MOTHER OF PEARL
ITT ROYAL
OPERA
PIONEER

PRINCESS OSRA
PRINCESS BEATRICE
QUAKER LADY
QUEEN CATERINA
SHEKINAH
SOUVENIR DE MME.
GIUDICHAU
SUNSET
SWEET LAVENDER
SEMINOLE
SUSAN BLISS
VALENCIA

A beautiful combination in a bed may be had by planting the following three inexpensive varieties:-BLUET, MRS. ALAN GRAY and KOCHI.

The price of Irises in the above list range from $15 \mathrm{c}$ to $\$ 50.00$ each.

Money is surely no object if a person is willing to pay the latter price for an Iris, but a great many people do so.

Most Irises increase rapidly and the prices decline as they are in better supply.

The price of Ambassadeur (one of the best) declined from $\$ 7.50$ to $50 \mathrm{c}$ in a year. Mother of Pearl declined from $\$ 10.00$ to $75 \mathrm{c}$ in the same time.

We are listing alphabetically as the names would appear in a telephone book, for instance, if you wish to find B. Y. Morrison, look for "M" and you will find it "MORRISON, B. Y." 


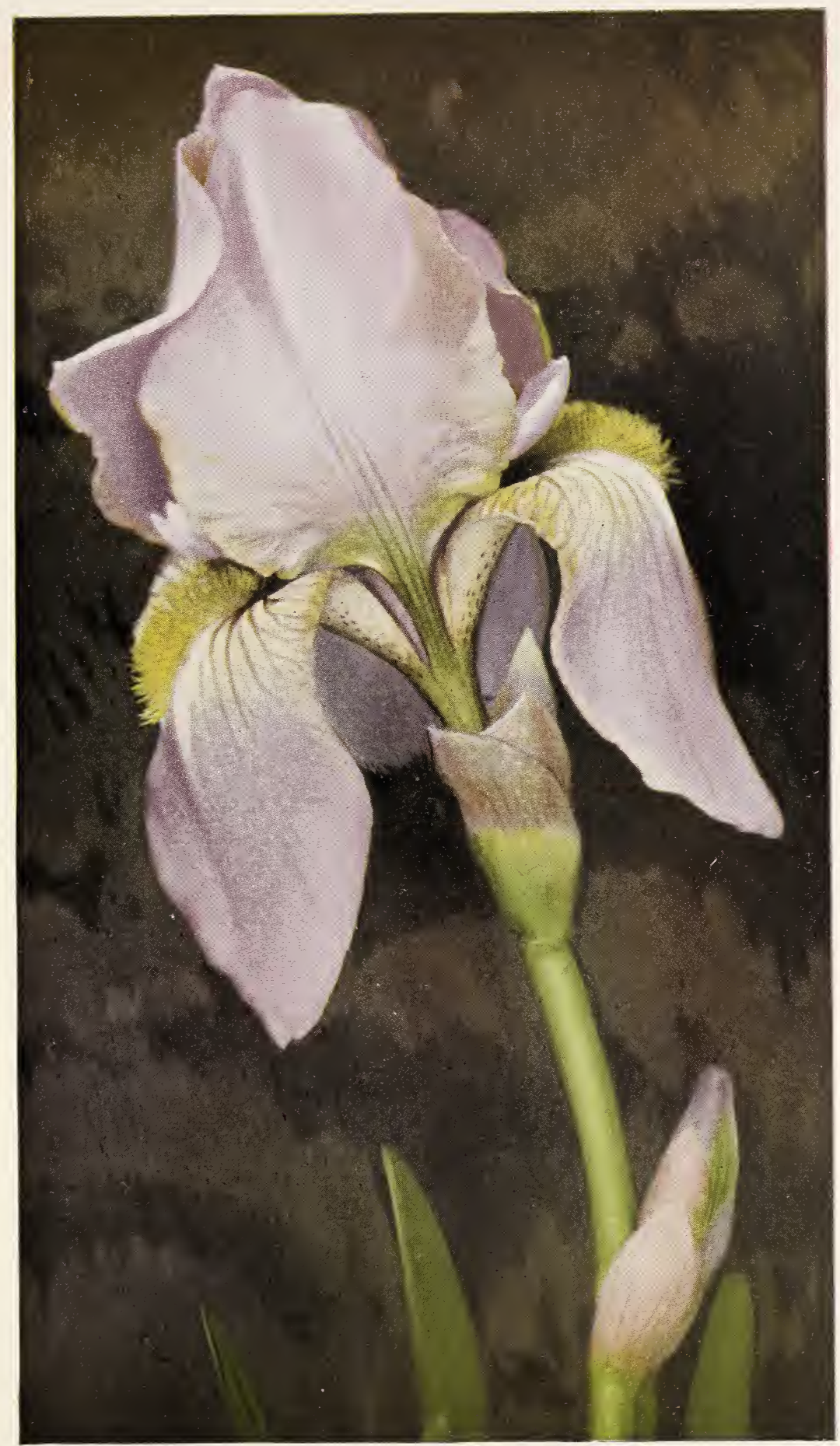

MOTHER OF PEARL

(Sturtevant) 


\section{THE IRIS}

ABENDA (Perry 1924) T. B.--_-_-_-_-- 2.50 This beautiful iris produces its mediumsized flowers in great profusion on stiff branching stems, quite early, and grows nearly four feet high. S. large and incurved. A delightful shade of old rose overlaid bronze: F. rich madder-crimson, suffused soft bronze.

ACHATES, (Perry) T. B.

Large well formed flowers. S. light purple, overlaid bronze, faintly lined purple; F. bright violet-crimson with a bold white lined base, conspicuous orange beard; extremely attractive.

8.6-AFTERGLOW (Sturtevant 1917) T. B. $\mathrm{S}$. and $\mathrm{F}$. delicate greyish-pink, shading to a rich yellow through center. Free bloomer, 40 inches.

AKSARBEN (Sass 1923) T. B. An uncommonly rich plicata; fawn and velvety-brown markings on a cream colored ground. 24 inch.

8.9-ALCAZAR (Vilmorin)

This is one of the best Irises in the world, and we do not believe we will have enough stock to fill all our orders, for it is an excellent value at the price S. light bluish-violet; F. deep brilliant purple, with bronze-veined throat. We have never heard of a disappointed customer, even when the price was $\$ 1.00$.

AMBASSADEUR (Vilmorin)

This has been the best selling variety in our list, and Mother. of Pearl, we believe will be the only variety which will exceed it in pouplarity this year. The plant is so tall and well branched, the blooms so large and of such great substance, that everyone likes it. S. lavender; F. deep red-violet, with a rich orange beard.

APHRODITE (Dykes) $S$. and $F$. bright violet-pink. The falls have a white fiush from the center of the blade to the haft. This variety is recognized as the world's best pink Iris. The general effect is a decided pink tone. Its good size and perfect form, with its prolific blooming habit, increase its popularity.

8.3-ARCHEVEQUE (1911) T. B S. deep velvety-violet; $F$. dark velvetypurple, immense flowers. 20-24 inches.

9.6-ASIA (Yeld)

This distinct and beautiful variety is unquestionably one of the most glorious Irises in cultivation. It is an exceedingly strong and tall grower, very free flowering with individual blooms of the largest size. S. pale lavender, suffused and reticulated yellow at the base. F. light violet-purple, paler at the adges, and heavily reticulated at the haft. Bright yellow beard. Height 4 to $4 \frac{1}{2} \mathrm{ft}$.

ATHENE (Sturtevant 1920) T. B. Warm white haft and claw, reticulated maroon on cream: beard lemon-yellow, style branches light buff-yellow on the sides. Strong grower, handsome, 33-in.

ANOSIA (Longfield 1925) A variety of rich brown coloring.

A large flowered species from Asia Minor. Broad but somewhat floppy standards of irridescent blue; falls smooth violet. Branched stems thirty inches high. Early.

AUNT RACHEL (Fryer 1919) T. B S. white tinged with violet; F. pansy violet, edged with white. Very fragrant. 24 inches.

AUTUMN KING (Sass 1921)

Although this variety increases very rapidly, the demand has always been ahead of the supply. It bloomed with us last year in August, Sept. and Oct. That is, different plants bloomed at these various dates. It attracts more attention than any other plant in our garden and is a beautiful flower aside from the novelty of blooming in the fall. Lavender falls standard. 27 inches high.

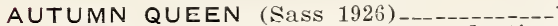

This is another remarkable introduction. A pure white fall bloomer. It was sold last year at $\$ 25.00$ and as it multiplies rapidily we have reduced the price this year to $\$ 15.00$.

8.3-AMBIGU (Vilm. 1916)

A free flowering vigorous variety that is much admired. S. smoky-red or magenta; F. velvety reddish-brown.

7.5-ANDRIST, DR. (Fryer 1919) T. B.---S. bronze-yellow; $F$. velvety-maroon with bronze edging; yellow beard. Fragrant. Very late.

AUSTIN, MONS. (Denis) This variety is very distinctive, making its approach towards red through a deep lilac-rose shade. We were particularly well pleased with it last year, and will be very glad to see it in bloom again.

AYMARD, MONS (Denis)

8.7-AVALON (Sturtevant 1918) T. B.-_-_- 5.00 One of the best Irises, light mauve flowers. Awarded a silver medal. Over $3 \mathrm{ft}$.

AZURE (Bliss)

This is a splendid rich purple Iris with very much the same color and quality as Dominion.

9.4-BALLERINE (Vilmorin) This Iris is of the Lord of June type and is almost universally admired. It does not increase as rapidly as Lord of June, but it has better standards and will withstand the heat of the sun much better than that variety. S. clear lightblue; F. a deeper blue. Tall and graceful in its growing habit.

BALARUC (Denis 1920) T. B. Standards and falls both white. Flowers medium size; pale golden beard and a few purplish markings at base of falls. Late and free flowering.

BALDER

This is one of Goos and Koeneman's fine 1926 introductions.

ANNE BULLEN (Hort) 2.00 Remarkable for the rich copper color of the haft which gives distinction to this tall, well branched variety. S. very large bluish-lavender; F. deep purple with heavy brown reticulations. The red tone of the fall, combined with the copper markings, produce an extremely beautiful, distinct effect.

\section{5}

5


BAZE, MADAME (Denis) S. and F. cream, flushed honey-yellow and shaded a livid brown. This variety is somewhat similar to Madame Chobalt, but we do not regard it as equal to that famous variety.

BEYNON, FRANKLIN (Perry) T. B. Medium height. $S$. broad and incurved, low beard; extremely dainty and greatly admired.

BORLES, MME. (Denis) 1.00

BEAU IDEAL (Sass 1924) One of MIr. Sass' finest plicatas; white violet on both the standards and falls. 32 inch.

BOULLET, MADAME (Denis) S. buff, deep red edge, brown lines at base; F. vellow, lined and dotted deep brown. Mid-season.

BRUN, MONS. (Denis 1920)

Very large flowers. $S$. ageratum-blue shaded with brown: F. light purple shaded brown. The general effect of the flower is a brown tone, so the flower is aptly named, as translated it is "Mr. Brown."

BELLADONNA (Koehler)

S. white, spotted and veined blue-purple; F. white edged violet.

7.0-BRAND, MRS. J. S. (Fryer) T. B.--..S pink-bronze, edged with light yellow; F. mahogany-red. Fragrant.

7.9-BENBOW (Bliss 1917)

$A$ deep violet blue self. Large flowers on tall well developed stems, 3 feet.

BREWSTER, MRS. WALTER (Vilmorin) -The color on this new variety is somewhat darker than Pallida Dalmatica, and the plant is not as tall as that famous old variety. S. lavender-blue; F. aniline-blue; good yellow beard. Free flowering. The variety has fine blooming habit, its branching stems often car-

BÉNRIMO (Perry 1924)

A very beautiful Cypriana variety, stout branching stems 4 feet, bearing many extra large well shaped flowers. S. large and incurved, a delightful shade of bright blue; F. light purple with a conspicuous white lined base; yellow beard; late flowering.

BENONI (Cengialti X Pallida) (Perry)---- 1.50 Small flowers produced in great profussion: S. bright rosy-purple; F. crimsonpurple; orange beard.

BATTEY, P. L. (1923) T. B. Mr. Fryer named this Iris for Mr. Battey, who described it as "a real honestto-goodness pink.'

7.5-BRAND, RUTH (Fryer 1917) T. B S. violet-blue; $F$. deeper shade of same. Yellow beard; medium sized flower with broad round falls; 28 inches.

BLACK PRINCE (Perry 1900) T. B. very late; one of the darkest Iris.

SUSAN BLISS (Bliss 1922) A uniform shade of deep rose-pink. The pleasing color tone. Tery free flowering light rose; $\mathrm{F}$. soft rose, white and yelwith an almost solid border of petuniarying six blooms at the same time. S. deep violet-purple; F. Black-purple; beard is light orange and adds a very
S. bright clear blue; F. intense dark blue, 30 inch.

7.2-BLUET (Sturtevant 1918)

Of an appealing blue tone and neat rab-

8.3-BLUE BIRD (Bliss 1919) T. B................. Small sized, self coloured, flowers of the brightest blue. Falls at right angles with the standards. Unusually intense blue coloring.

8.1-BLUE LAGOON (Bliss 1919) T. B $A$ pale blue bicolor of good shape. A refined and lovely flower.

COWLEY, MRS. (Biiss) S. coppery-buff; $F$. deep rich rosy-purple. Early prolific bloomer.

CUTHBERTSON, MRS. W. (Perry 1923) An exceedingly handsome Iris of noble proportions, stems stout and branching, ovel $4 \mathrm{ft}$ high. $\mathrm{S}$. soft rose overlaid apricot, faintly lined old rose; $F$. bright rosy-crimson, edged silver.

CANARI (Denis) a good light yellow-_-_- 1.00

CHRISTMAN, W. F. (Fryer) $S$. pale lavender; $F$. violet with white markings. Early.

CAPORAL (Bliss 1919) T. B Bright reddish-violet self, large flowers. Vigorous free bloomer.

7.5-CAPRICE (Vilm. 1904) T B S. rosy-red; $F$. deeper rosy-red, shading toward white at centers. A fine red purple.

COLIAS (Longfield 1925) A three-foot yeilow self. Pleasing blooms that carry well in the garden.

CARTHORIS (PeIry) T. T. Fine for massing; S. bright mauve-blue; F. light rosy-purple; white beard, very free.

8.1-CARTHUSIAN (Marshall 1906) T. B.-$\mathrm{S}$. clear lavender-blue; $\mathrm{F}$. deeper blue.

Gigantic flowers produced in great profusion; S. large, incurved beautiful shade of rose-violet: F. fully 3 in. long, crimson overlaid black with a bronze base, bright orange beard.

CORNUAULT, MONS. (Denis)

$S$ lavender, washed buff; F. crimson, very faintly tinged with purple; reddishbrown reticulations at base. Mid-season. We understand the originator considered this one of his best varieties.

CHABERT, MONS. 1.50

CHOBAUT, MADAME (Denis) $S$. cream. shaded buff and pink, tinted lilac at the edge; $F$. white reticulated violet at edge. Orange beard. Midseason. This Iris has been a favorite ever since its introduction.

7.8-COOPER, MADISON (Fryer) T. B.-$S$. lemon-yellow; F. maroon-red; orange beard. Fragrant. it. A cengialti seedling, 2 feet.

CASSANDAR (Perry 1923) 
8.4-CHER!, MME. (Sturt. 1918)

A tall, strong growing, free flowering variety. The color is exquisite ageratum-violet, washed with pink and warmed by the yellow undertone. A rich pink effect at a distance. 4 feet.

7.4-CHEREAU, MME.

White elegantly frilled with a wide border of pale blue. Large flowers on a tall stem. One of the most beautiful.

CAMELOT (Bliss)

This is the best effort the English growers have made to equal the famous American variety, inna Farr, the Iris with the penciled or picot edge. I like the American variety because it has the better form and substance, but the English originator has beaten us in size. Real Iris enthusiasts will want both varieties in their gardens. Standards and falls creamy-white edged with pale violet.

8.9-CATERINA (Fos. 1909)

Massive lavender flowers on $4 \mathrm{ft}$. stems. $S$. bluish-lavender; $F$. soft lilac. One of the most wonderful Iris in cultivation.

CAVALIER (Cleve. 1920)

$\mathrm{S}$. fine clear blue, dome shaped; F. deep velvety-purple. A great improvement on Azure and Perfection. One of the most beautiful blues. We heartily recommend it to our customers.

CENGIALTI-LOPPIO (Perry) Extremely pretty; very floriferous, rich violet-blue. May flowering.

\section{CEN.-PERRY'S FAVORITE}

One of the most beautiful Iris yet produced, slender much branched stems, bearing a profusion of large, well shaped flowers, uniform shade of rich violet illuminated with a most remarkable white beard.

fl

CENGIALTI-THALIA (Perry) Quite distinct; S. light biue; F. light crimson-purple, bold white beard; extremely pretty; mid-season.

CENGIALTI-THORA PERRY

A charming pigmy form, offered for the first time; growing well under $1 \mathrm{ft}$., small flowers. A uniform shade of violet-rose; a dainty little variety.

CHASSEUR (Vilmorin) A new yellow Iris from France, and it is a much better yellow variety than ever before came from that country. S. bright straw-yellow; F. same color with red markings at the base. It will have to compete with Citronella and the best Imerican yellow varieties. The world is anxious to obtain a good, tall growing, yellow Iris.

CHATELET (Vilm. 1923) S. lavender, shaded pink; F. deep lilacpink reticulated white on blade, brown at base. Large fowers very freely produced. A new variety of merit.

7.8-CLEMATIS (Bliss 1917) Unique shaped like a fine Japanese Iris or a large six-petaled Clematis. All six segments of the flower reflect horizontally. Color large clear violet with veining at base. Strong grower, free flowering and fragrant. 30 -inch.

8.6-CLUNY (Vilmorin)

Tall growing with flowers of the largest size. S. wistaria-violet; $F$, soft bluishviolet, evenly marked purple-brown on cream ground, the reticulations extending below the bright orange-yellow beard. One of the most vigorous varieties.

CORA (Millet)

S. violet to purple bronze at base; F. deep violet with white markings at base.

CORBIE (Denis) Very rare-_-_-_-_-_-_----- 1.50

CORDELIA (Parkel' 1873)

S. rosy-lilac; F. rich crimson-purple, handsome floriferous, late flowering.

CONNELL, C. P. (Fryer) T. B. S. bright blue; $F^{2}$. blue with purple tinge; light yellow beard; 36 -inches. Fine laige foliage.

8.9-CRIMSON KING (Hallock) Rich claret-purple. A splendid standard variety.

CRUSADER (Foster)

$S$, and $F$, are both lavender-biue with a slightly deeper shade in the falls; beara orange-yellow; erect growing, fiee flowering.

CYBELE (Perry) T. B.

Extra large weil snaped flowers; S. dark lavender-blue; F. rich crimson-purple, conspicuous bronze beard. Tery rare.

CITRONELLA (Bliss)

This is the very best yellow Iris from England. Its carriage is perfect, and so are its standards, but the falls are somewhat of a disappointment, as they are smaller than they should be, and show too much of a dark shade to permit the varieiy to be called a perfect yellow Iris. It is i.. very great demand among breeders a:id collectors.

CANDELOT, COLONEL (Millet)

This is one of the good Irises which makes the best approach to red in color, and as it is very vigorous, I believe all American Iris lovers wiil be glad to own one. S. bronze, overlaid with red-lavender; $F$. rich velvety crimson purple, reticulated white at the base. yellow beard.

CLAVAUD, ARMAND (Denis) Smail flower. S. intense canary yellow slightly penciled violet all over; F. white dotted naroon and nargined canaryyellow.

7.6-CRANDALL, E. L. (Farr 1915) S. pure white; F. white, heavily bordered deep blue at the base, 18 -in.

CHATENAY, MADAME ABEL (Cayeux) -.This is a very good bloom and our records show that it has a pronounced redlilac effect and the quality was marked "high."

DALILA (Denis)

$\mathrm{S}$. white, slightly tinted lilac: F rich violet-red with some white and brown veins at kase. Orarge beard. A most excellent variety.

DAWN ( Yeld)

This variety, like Afterglow, IIorning Splendor and Nother of Pearl, is aptly named. It has the colors of the eastern sky before the sun appears. A beautiful sulphur-yellow, brorze veired at the throat.

DAISY HILL (Smith)

The standards are a deep but still soft blue-violet: Falls deener with more violet in the blue. We believe our customers will find this a bargain.
30

.15 
This pretty variety is quite distinct, a charming combination of colours; standards, spricot, suffused rose; falls bright crimson-purple irregularly edged grey.

DEUL DE VALERIE MAYET (D.1912) T.B. 1.50 S. coppery-pink; F. red-bronze, medium size flower, strong plant.

DIADEM (Bliss 1919)

A strong grower with stout stems $31 / 2 \mathrm{ft}$ high. S. pale mauve; F. deep reddishmauve, brilliant orange beard

DIANE (Vilmorin) A charming blue Iris_- .50

DIDO (Perry) T. B.

A very beautiful variety of Alcazar; $S$. large and incurved, bright mauve overlaid bronze; $F$. over $2 \frac{1}{2}$ inches wide, brilliant crimson-violet; very free; exceptionally fine.

DIMITY (Bliss)

S. white, slightly veined mauve; F. very wide and large, veined lavender; beard white tipped brown.

DOMINION (Bliss)

S. of Dauphin's blue or light bluish-violet, large, erectly held, well developed and richly veined; $\mathrm{F}$. of exceptional substance, expanding at the base to a deep rich indigo-purple velvet. There is a little veining in the throat, violet-purple on white ground. Beard orange, very pronounced. Quality of entire bloom is the very best. The plant, however needs extra care, perfect drainage and probably some protection from winter and spring rains. Stock limited.

DORINDE Another of Millet's good seediings. Scarce.

7.9-DORMAN (Bliss) S. reddish-violet; F. red-purple. A beautiful rich red-purple neglecta variety, with flowers of good form and medium size. Very free flowering. Most effective when used for mass planting.

7.6-DOROTHEA (Caparne 1901)

Lilac-blue, tinged with white; $\mathrm{S}$. flat like a Japanese Iris.

8.5-DREAM (Sturt. 1919)----_...---.----$A$ very beautiful Iris and a very near approach to the perfect pink self color Flowers are large, of perfect form and great substance, beautifully held on stems 38 inches high. This is an indispensable variety.

DESORMES, CLEMENT

Another of Denis' very scarce and beautiful varieties.

DUMAS, J. B. (Denis) T. B Flowers large, splendid tint of rose, slightly tinged with violet. F. creamywhite.

7.8-D'ARC, JEANNE (Verdier 1907) White delicately frilled lilac. Very fine. 30 inclies.

DE GENLES, MME. One of Denis' outstanding varieties. Scarce.

DE SEVIGNE, MADAME (Denis) $S$, bright violet; $F$. white with bright markings and bordered violet. Brownish-yellow beard. This Iris is larger and more striking in color than Madame Chobaut, but it does not appear as refined. Mid-season.
DURRAND, MADAME (Denis) 2.50

S. tawny buff: $F$. rich creamy-yellow shading to buff, the lower half overlaid with mauve. Rich brown reticulations. This variety is one of the largest and most beautiful in the world, but it must have perfect drainage.

DE GULLY, MONS (Denis) 2.00

ECLAIREUR (Cayeux 1923) T. B S. white hardly reflected fine lilac: $F$. rosy-violet suffused and richly edged clear lilac. Throat reticulated buff on a white ground. A magnificent variety. Unusually free flowering.

7.8-EL DORADO (Vilm. 1910) T. B. S. yellow-bronze, shaded with heliotrope; F. violet-purple with bronze-yellow tints. 30 inch.

7.9-EMIR (Yeld 1918) T. B. 1.00 S. pale blue; F. very dark purple-blue. Tall, vigorous, free flowering.

7.5-EMPIRE (Sturt. 1918) T. B A rich yellow in the sun, but often dulled with faint veins in a moist atmosphere. 30 inches.

ERATO (Perry) (Cypriana) Tall branching stems, large well built flowers. S. glistening silver-blue; $F$. light purple-blue, light golden-yellow beard, surrounded with a white halo.

8.4-FRYER, W. J. (1917) T. B._-_._-_._- .75 Large yellow; F. maroon, with yellow border; center overshadowed violet. 30 -in

7.9-FRYER, MRS. W. E. (1917) T. B. S. white, shaded heliotrope; F. purplecrimson bordered a lighter shade; white veins from center to base. Orange beard 32-inch.

FARSITE (G. \& K. 1926)

FOLKWONG (G. \& K. 1926)

8.0-FAIRY (Kennicott 1905) T. B. White, delicateiy bordered with pale blue. Tall and fragrant. A great favorite. 40 -inch.

FERDINAND (Newlands 1923) T. B.-.--- 3.00

FERONIA (Perry) T, $B$

A fine strong variety with large well built flowers. S. unusual shade of soft rose-bronze; $F$. old rose heavily lined madder-crimson, rose and white halo surrounding its pretty sulphur beard.

FIRMAMENT (Groschner)

S. clear light blue; F. bright blue, with purple in center and bright orange beard. Prolific and vigorous.

7.0-FLAVESCENS (DeCandolle 1916)_-...-. . A delicate shade of soft yellow; large sweet scented, fine for massing. Early. 30 -inches.

7.6-FLORENTINA ALBA _. Creamy-white. An Italian native species.

RITJOFF (Intermediate)

7.5-FRO (G. \& K.)..._- 15 S. deep gold; F. brilliant chestnut brown with narrow border of gold. 2 feet

FRYER'S GLORY (Fryer) One of the best of the Fryer varieties. S. golden-bronze, tinted erimson; F. bright velvety-maroon, veined light yellow.

8.5-FARR, ANNA (Farr 1913). S. white, lightly bordered pale blue; F. pure white witl pale blue markings. Very large and beautiful. 36-inch. 
8.1-FRYER, KATHRYN (1917) T. B.----- .85 S. large bright yellow; $F$. maroon, veinOrange beard. Fragrant. 32-inch.

GERARD, MONS ALPHONSE (Denis) -.-- 1.50

8.4-GRAY, MARY (Farr 1913) T. B._-_. .30 S. clear lavender-blue; F. dark lobeliablue. Large flowers, 36-inch. 7.8-GARDEN, MARY (Farr 1913) T. B.----
S. pale yellow, flushed pale lavender; F. cream-white, minutely dotted and veined with maroon; 30 -inch.

GLOVER, HENRI (Denis)-_-_-_-_-_._-_. 1.00

7.6-GRAY, MRS. ALAN (Foster 1909) T. B. .15 $S$. and $F$. delicate rose-mauve. Free bloomer, vigorous; 30-inch.

GALLOWAY, BERNARD (Perry) T. B.--- 2.00 Extremely pretty, medium sized flowers; S. soft violet-rose; F. bright rose lined purple, yellow beard; remarkably fine, unique for massing.

GAITE (Vilmorin)

1.25

8.9-GEORGIA (Farr 1920)

A uniform soft shade of Cattleya rose with bright orange beard. Early, bright, free flowering and vigorous. Especially valuable, as it it the earliest of the pinks. 2 feet.

GERNEZ (Denis)

GLITTER (Bliss)

S. bright golden-yellow: F pale chestnut-brown, with soft yellow margin. One of the best of the new variegatas. A fine variety for massing.

GNOME (Bliss)

S. lilac with a touch of pink; deep lilacrose or violet. Good bloom, outstanding in color.

GOLD CREST (Dykes)

S. and $F$. bright violet-blue with a conspicuous golden yellow beard. Aptly named. A profuse bloomer and vigorous grower.

7.1-GOLIAH (Cayeaux 1908) T. B Similar to Prosper Laughter, but F. are deep purple instead of crimson and $\mathrm{S}$. a pale bronze.

GLORY OF HILLEGOM

This is called a blue Iris but it is not as true a blue as Corrida. It is a splendid growing variety. A fine Iris for border planting.

7.1-HUGHES, GOV. (Fryer 1919) T. B.--- .50 $\mathrm{S}$. deep violet, tinged red; $\mathrm{F}$. deeper shade. Large orange beard. Fragrant. 27 -inches.

GREVIN (Vilmorin)

$\mathrm{S}$. bright violet; $\mathrm{F}$. rich velvety-purple. Blooms of good size and fine carriage.

8.8-HALO (Yeld)

Soft and delicate tones of lavender-blue and verbena-violet with the standards very softly tinted.

7.9-HARRINGTON, BARTON (1919) T. B.S. bright golden-yellow; F. brown tinted with red, bordered bright golden-yellow. Fragrant.

HARPALION (Perry 1923) Gigantic flowers, well formed and freely produced on well branched stems over 4 feet high. S. lavender overlaid bronze; F. clear lavender-blue. A very beautiful flower.
HELVETIA (Perry) T. B.-_-_-_ 2.50 Large well shaped flowers of great texture. A pretty and novel combination of colour. $\mathrm{S}$, rose overlaid bronze; $\mathrm{F}$. crimson suffused silver, brown reticulated base. $3 \frac{1}{2}$ feet.

HUBERT, MONS. (Denis)

HESTIONES (Perry) (Ricardi hybrid) Very tall stout oranching stems bearing many large flowers. A delightful shade of silvery sky-blue; massive light blue falls, with a conspicuous white lined base.

HAW, MRS. (Perry) T. B

S. light lavender-pink; $F$. dark lavenderpink to ward the edges. Yellow beard. 30 inches.

HIAWATHA (Farr) $\mathrm{S}$. pale lavender: $\mathrm{F}$. rich velvety pansyviolet reticulated white at base and edged lavender; mid-season. HIPPOLYTA (Hort) - Flowers of good size,
Mauve in color. fine shape and splendid carriage. Vigorour growing habit.

HOOGIANA

A most charming Regelia Iris which is hard to establish in this country excepting on the Pacific Coast. We planted a number last fall which are still alive as this is written. Price after it blooms.

HUSSARD (Vilm, 1924) An excellent deep toned blue self. Vigorous. Very scarce.

IBERICA (Pallida) -

IMPERATOR (Cayeaux) -_-_-_-_-_-_.-- 3.00

S. clear violet tinted buff; $F$. reddishviolet, throat reticulated with red-brown. This is one of the most promising of the new Irises from France.

INGRES (Cayeaux 1922) T. B S. lilac-heliotrope; F. heliotrope and violet. Smoked colour. Distinct.

7.1-INNOCENZA (Lemon 1854)----------- .15

7.9-IRIS KING (Goos \& Koeneman)_-_._- .20 Its bright, clear colors make it one of the most popular Irises among the variegatas. S. clear lemon-yellow; F. rich maroon, bordered yellow.

8.6-ISOLINE S. lilac-pink, tinged with buff: F. purplish old rose. A grand distinct Iris, stems. One of the most beautiful Iris in the world.

7.3-IVORINE (Caparnne 1901)-_-_-_-_-_- .15

8.0-JACQUESIANA (Lemon 1840)......... . .30 One of our best sellers. An excellent old variety with copper-crimson standards and maroon falls. 3 feet. JAPANESQUE (Farr 1922)
A unique variety. The six petals, spreading horizontally in the form of : Japanese Iris, give the effect of having six falls and no standards.

JUBILEE (Sass 1923) T. B.

A ruffled heavy textured flower with peach tinted standards, the haft and edge of the flaring white falls peppered. 30 inches.

8.1-JUNIATA (Farr 1909) T. B...-...Clear blue. $S$. arching and $\mathrm{F}$. flaring. Large and fragrant. 42 -inch.

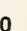


JENKINS, E. H. (Pliss 1919)

A free flowering variety of vigor with stout branching stems. S. pale steel blue-purple; F. of a deeper tone. Outstanding.

JESSOP, MISS (Perry) T. B.

A very pretty Iris, medium height, neat branching stems, bearing a profusion of medium sized flowers, uniform shade of light purple-blue.

7.6-KNYSNA (Bliss 1917). brown. Free flowering and vigorous. 32 inches.

7.8-KOCHII

The old, early, dark"blackish-purple self.

LONGDON, DORA (Bliss) fused with yellow; $F$. rich red-lilac suffused at haft and edge with yellow. Mid-season.

LESUIER, DANIEL (Denis) 1.00

LEPINEAUX (Millet) analine-blue 1.00

LYCAENA (Longfield)

An amoena which we consider particularly fine. The flowers are of good shape and the pale margined falls, of a deep shade of rich purple, are in clean and beautiful contrast to the white standards. Mr. Mead has referred to this Iris as superior to Rhein Nixe and

LEONATO (Hort)

Very much taller, flowers very much larger and lighter in tone than Lady Foster. Unquestionably the finest bi-color in the world. From the tip of the standard to the tip of the fall it measures over 6-in. Larger than any other Iris in existence with the exception of Ricarai Blanc, Bleute and Peerless. This ought to rate at least $95.4 \mathrm{ft}$. John C. Wister in Bulletin No. 7 of American Soing more beautiful than this flower can be imagined.'

LOWELL (Fryer) T. B Large and fragrant. 26-inch.

8.5-LADY FOSTER (Foster 1913) let. Large fragrant flowers of great beauty on three and one-half foot stems. Very fine.

8.3-LA NEIGE (Verdier) This might be termed a standard white variety. It is a good grower and much more reliable than Kashmir White.

LA NUIT (Denis)

S. violet-maroon; $\mathrm{F}$. rich pansy-violet with yellowish touch, washing off lighter. This French variety is very well named, for we understand LaNuit to mean "The Night."

LADY BYNG (Bliss)

"A very beautiful Iris. The flowers are of exceptionally fine form and substance. The color throughout is a clear pale lavender with a slight suffusion of rose. Very free flowering and increases qujrkly." The rhizomes of this variety, like those of Susan Bliss, and some other varieties, are very small. I suppose there is a strain of Cengialti blood in their ancestry which is responsible for the small size of the rhizomes. S. clear deep yellow; F. deep velvety-

A popular variety. S. pale lavender sufequal or superior to Daphine. ciety, page 10 , says of this Iris: "NothS. light purple, fall a darker purple.

Standards pale blue; falls lavender-vio-
LANCELOT (Bliss)

Self colored flower of pale lavender with bright orange beard. Late.

LAVENGRO (Bliss)

S. dark coppery-crimson; $\mathrm{F}$ rich maroon. The color combination makes it distinctive.

9.1-LEVERRIER (Denis 1917) -

One of the finest French introductions. $S$ a beautiful shade of mauve. F rich pansy-violet. Large flowers on tall branching stems. A valuable variety in the garden on account of the clear tone of the falls. An excellent show variety. Fragrant; vigorous, to 42 -in.

8.2-LOHENGRIN (G. \& K. 1910) Large self of a uniform shade of light Cattelya rose.

9.1-LORD OF JUNE (Yeld 1911) A very large, light bi-color. S. chicoryblue; $\mathrm{F}$. lavender-violet, drooping. This Iris is universally admired. A fine show flower. Fragrant; vigorous, $3-\mathrm{ft}$.

7.9-LORELEY (G. \& K. 1909) A light yellow and purple bi-color. $F$. bordered yellow. The most free flowering of any of the older sorts. Excellent for landscaping.

7.7-LESLIE, ANNE (Sturt. 1918)

A dainty variety of pleasing color tone. S. white faintly rose flushed; F. dahliacarmine, to 30 -in.

LONA (Sass 1923) T. B

Standards sanded with pale purple on white, the falls purple with a yellow sheen, the flower enlivened by the yellow haft and beard. 30 -in.

LORD LAMBOURNE (Perry 1924) T. B.-- 6.00 A magnificent variety and one destined to become one of the world's favorites. Perfect habit, branching stems over $3 \frac{1}{2}$ feet high, bearing a profusion of large well shaped flowers; the colour combination is a pleasing one a delightful shade of rose-fawn suffiused with pale bronze; $F$. rich madder-crimson with a white reticulated base. illuminated with a bright yellow beard.

LOCHESIS (Perry)

Remarkably early and floriferous, produces its dainty little flowers in April and Mav. A pretty uniform shade of light rosy-mauve.

8.1-LOUESSE, MME.

A yellow toned plicata. S. cream, bordered reddish; F. cream, striated with red. An old variety, but quite scarce.

9.1-MAGNIFICA (Vilm. 1920) The flowers are extraordinarily large, $6-$ in. high and sweetly scented. S. light violet-blue: F. dark reddish-violet. One of the finest varieties.

MAGNIFICENT (1922) T. B.

This is Mr. Frver's best Iris and Mr. Campbell, the Detroit specialist, thinks it may head a new race of giant flowered Irises like Dominion. S. rich violetrose: $F$. rich velvety-crimson. Orange beard.

MAIDEN'S BLUSH (Perry) T. B. 1.00

Extremely free stout stems nearly $4-\mathrm{ft}$ high, well set with medium sized flowers. S. soft lilac-rose; F. soft rose, yellow beard, almost uniform colour.

.60 1.00

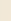

(1)

.00


MA MIE (Cayeux)

$S$. and $F$. white, bordered with blue reticulations. Very much like Anna Farr, but the falls are not so circular. Early. One of the best standard Irises.

8.1-MANDELAY (Sturt. 1918) T. B.

A pale violet self with the fresh fragrance of a water lily; a seedling of Caterina; 42 -inch.

\section{MACRANTHA}

\section{3-MANDRALISCO (Species)}

MARCUS (Perry)

Dwarf; very late; medium-sized flowers. S. rich golden-yellow; F. madder-crimson, conspicuously edged old gold; white lined base.

MASSE, MME. (Denis)

MAYO, DR. C. H. (Fryer 1924) T. B.

MANTOR, DR, (Fryer) T, B. S. light coppery-crimson; F. maroon, bordered bronze-yellow: nearly the entire fall reticulated white and yellow. Orange beard; fragrant.

MARLOW, JULIA (Shull 1924) T. B. S. Chinese-violet: $F$, raisin-purple; a pink and red effect.

MONET, MME. CLAUDE. (Denis 1912) T. B. 3.50 Velvety, dull, dusky purple; fine; scarce.

MOOR, MARGARET (Bliss) A deep lilac-rose or light red-lilac variety in which the standards are slightly darker than the falls.

MARSH MARIGOLD (Bliss 1919) T. B. S. pale golden-yellow: F. purple-brown with a conspicuous yellow edge. $27-$ in.

MELPOMENE (Perry) T. B. A late variety of outstanding merit; stout branching stems over $41 / 2$ feet high; large well shaped flowers. S. dark lavender-blue; F. rosy-blue; orangeyellow beard.

MENETRIER (Denis) S. pale yellow; F. dull, but strong yellow washed with plum-violet, paling to clear yellow.

MIDWEST (Sass 1923) T. B.

A ruffled flower dusted and dotted with deep rose-violet on a white ground. Iultiplies rapidiy. 30 -inch.

7.8-MINNEHAHA (Farr 1912) T. B. S. creamy-white, shaded yellow; F. creamy-white, with maroon markings. Fragrant; very large; 21 -inch.

MIRANDA (Hort 191) A very beautiful deep blue purple Iris of perfect form and carriage. One of the earliest of the tall bearded varieties: free flowering and of strong growth. Fine in every way.

MARALBA T. B. Standards rosy-lavender. Falls white veined.

MINNESOTA (Eryer) T $B$ S. bright golden-yellow; F. maroon-red. Orange beard; fragrant.

7.5-MITHRAS (G. \& K. 1910) T. B. S. light yellow; F. brilliant wine-red, bordered deep yellow; 30-inch.

MONASTIR (Cayeaux 1922) T. B $\mathrm{S}$. clear violet-blue; F. violet-purple. Strong variety for group purpose.
8.4-MONSIGNOR (Vilm. 1907)

S. rich satiny-violet: $F$ maure, heavilv veined and centered velvety-purple Very fine flowering and vigorous. To 30 -inch.

8.5-MOLIERE (Vilm. 1920) $S$. violet-blue; $F$. deep rich velvetyviolet, veined brown. Beard yellow. Flower darker, but as good as Magnifica though not so tall. 30 -inch.

MORNING SPLENDOR (Shull, 192)

Considered by some the finest American introduction. When planted so that the low lying morning sun may be seen thru it, the appropriateness of the name becomes evident. S. petuna-violet; F. raisin-purple. Strong growing and $a b-$ solutely hardy.

MOTHER OF PEARI (Sturtevant) Standards and falls pale bluish-lavender, with a faint creamy unciertone. Large flowers of perfect form and exceptional substance. The creamy undertone of this exceptional substance often assumes the luster and iridescence which we see in the beautiful lining of many sea shells which produce Mother of Pearl. The plant is tall, a vigorous grower, and a profuse bloomer. See color illustration. The best Iris value of the year. Six rhizomes for $\$ 4.00$.

8.2-MT. PENN (Farr 1909) T. B. S. lavender-rose: F. crimson-lilac; deep orange beard; 30 -inch.

MUZERIS (Perry) Extremely pretty medium-sized well shaped flowers. S. clear Apricot flushed old rose; F. bright rosy-crimson. A charming combination of colours.

8.5-MORRISON, B. Y. (Sturt.1918) $S$. soft lavender; $F$. velvety-purple with broad margin of lavender. A distinct and beautiful variety which we can recommend highly.

MINTURN, CECILE (Farr 1922)

One of the best light "pinks." " Very free flowering and vigorous. Later than Georgia. A fine landscape variety.

MICHEL, EDOUARD (Verdier) S, rosy-mauve; F, mauve, Flowers unusually large, handsome and distinct in color. This is a grand Iris of imposing appearance. The flowers are well held on tall spikes and the shape of the bloom is excellent.

8.1-MOORE, VIRGINIA (Shull 1921)_-_...- .50 A very good late tall yellow self. 32 -inch.

NAVAJO (Farr) S. light bronzy-yellow, shaded lavender; F. deep maroon, heavily veined white and yellow. Stigmas yellow. Deep orange beard.

NEPTUNE (Yeld) S. pale-blue: F. rich dark purple-blue. Tall and well branched.

8.0-NINE WELLS (Foster 1909) Standards lavender-violet; falls deep velvety-purple. Large flowers on heavy stems forty inches high. A fine outstanding purple Iris.

7.3-NIEBELUNGEN (G. \& K.) -----Very large flower on tall stems.

NAZARIN (Foster)

S. light purplish-violet; F. darker. 
8.2-ORNE, NANCY (Sturt. 1921)

A very large flower, $S$. purplish-lilac, shaded to fawn. Falls argyle-purple shaded yellow. The general effect is a fawn-pink flower.

8.7-OPERA (Vilm. 1916) A rich violet-red bicolor. 30 -inch.

7.9-OPORTO (Yeld 1911)

Standards and falls violet. The flowers are not large but have a certain neatness and finish. making this a beautiful Iris. 30 -inch.

7.8-ORIFLAMME (Vilm. 1904)

Derived from Amas and with flowers much like that species. Standards lavender-hlue; falls violet-purple. Stiff stalks 30 -inches high.

OLYMPUS (Perry 1923)

A variety with large heavily built flowers, which are produred freely on stout branching stems; S. broad, incurved, rose overlaid soft bronze; massive. F. over 2-inches broad, madder-crimson, heavily reticulated white at base.

8.2-ONNORIS (Sturt. 1920)

Pale straw-yellow dusted with lavender; delicate tints that make this variety ideal as a cut flower. Vigorous and free. To three feet.

OUR KING (Denis)

S. light purple; F. rose to dull purple.

8.2-ORNE, NANCY (Sturt. 1921)-_-_-_-_-_-1.00 Standards purplish-lilac; falls deeper; Center of flower showing some yellow. growth vigorous; 3 -feet.

PALLIDA DALMATICA

$\mathrm{S}$. and $\mathrm{F}$. both lavender-blue. Although this is one of the very old Irises, yet it is better and more attractive than some newer varieties, which are sold at many times its price.

PALLIDA-KULAN TITH A very beautiful form. large incurved standards, rich skv-blue; F. delightful shade of soft lavender-blue. One of the best of Perry's Pallidas.

PAULINA (Hort)

This Iris has a nleasing lilac-pink shade. It is not as tall as Prospero, but it has a splendid garden effect, and, unlike some of the Hort varieties, it withstands our changeable climate.

7.5-PAULINE (Farr)

This Iris is very rich rose-lilar in color darker than Caterina. its silky petals forming a good contrast with its deep orange beard.

PEAU ROUGE (Cayeux)

S. coppery-red; F. violet-carmine, reticulated yellow at hase. Bronze-yellow beard. This seems to be a very good Iris, and was very much admired in our garden. It makes a good approach toward red. Mid-season.

PERFECTION (Barr) S. light blue; F. dark velvety violetblack with orange beard. Mid-season. This is an old variety, but it is also a universal favorite.

8.1-PARC DE NEUILLY (Verdier 1910) -A rich late plum-purple self which we can recommend. Vigorous; three feet.

PAGE, ANN (Hort)
This is a lovely pale lavender-blue Iris, This is a lovely pale lavender-blue Iris, flowers are large and of splendid shape. An excellent Iris.
PEGASUS (Perry) 1.00

Free blooming and one of the best striking Trojana varieties. S. brilliant blue; F. dark purple; dwarf; mid-season.

PION, MADAME BLANCHE (Cayeux) -.. $S$. soft bronze-yellow; $F$. standing at right angles, lavender-blue, with silver shaded margin.

PRINCESS OSRA (Bliss)

Free bloomer and vigorous grower. with erect habit. Color, clear white, lightly spotted and edged pale blue.

8.3-PROSPER LAUGIER (Verdier 1911) S. an iridescent sorghum-brown; F. velvety, bordeaux to Indian purple. Vigorous, to three feet.

PROSPERO (Yeld 1920)

A large blended violet bicolor with smoothly rounded falls. In a class with Asia, which it resemhles in shape. $S$. pale lavender, flushed yellow at base; F. deep red-purple with light shading at margin; to four feet.

PRINCE LOHENGRIN (Mohr 1923) A greatly improved Lohengrin. Practically the same color, but larger flowers and taller stems.

PIONEER (Bliss 1924)-_-_-_-_-_-_-_-_.00 A magnificent new Iris, the best redpurple in cultivation. S. large and incurved, colored bright red-purple. F. very broad and strong, in color, a deep glowing red.

PERONNE (Denis)

Very large flowers, an exquisite shade of lavender-blue.

8.0-POWHATAN (Farr 1913) S. light bishop-violet with deeper border: F. deep purple shaded crimson. Vigorous; three feet.

9.5-PRINCESS BEATRICE (Barr) This is the true variety and one of the finest iris in cultivation. S. lavender; F. slightly deeper tone with iridescent sheen.

PROSPERITY (Sturt. 1924) T. B. 3.50 A gigantic nower with flaring falls carried on tall branching stalks, in color lilac and hyacinth-violet, resembling Prospero, but of a redder tone.

PERTHUIS, OLIVER (Millet 1921) $-1.00$

$S$. manganese-violet; F. pansy-violet.

PERRY'S BLUE

A wonderful shade of sky-blue. Generally regarded as the best of the Siberian Irises. 4 feet.

7.1-PRESTIGE (Sturt. 1918) T. B.---Lioht lemon-yellow, the center of the
falls white, sparsely veined violet, bright and airy; 2 feet.

7.2-PRINCESS VICTORIA LOUISE G. \& K. ${ }^{1910)}$ T. B.S. sulphur-yellow; F. rich plum, with
distinct border of cream yellow. 28-in.

7.7-PRINCE VICTOR (Cap. 1901)-..--..15 $S$. lavender-buff; $F$. velvety-purple.

PHILLPOTTS, EDEN (Perry)--(Cengialti $X$ Fallida)--A very beautiful
Iris, one of the most striking varieties Iris, one of the most striking varieties ed in profusion quite early in the season. A pretty uniform shade of dark lavender-blue, relieved with a bold white and yellow beard. 

Pale mallow-pink, veined purple.

7.4-PUMILA ATROVIOLACEA $S$. violet-mauve; $F$. maroon-red.

PRESBY, HARRIET (Presby)

A very tall vigorous Iris which has extra large blooms of Mrs. Alan Gray shade of pink-lilac. One of the most vigorous growers. Extra fine. We do not hesitate to recommend it.

PRESBY, MILDRED (Farr 1923)

This is Farr's masterpiece and in it he has given us one of the most beautiful Iris in the world. It is unquestionably the finest one of the Amoena type which has been introduced. S. white, faintly flushed pale, rosy-lavender. F. rich, dark, velvety pansy-violet, with a very narrow edge of lavender-white.

8.4-QUAKER LADY (Farr)

Nature has taken emoky lavender, acquamarine-blue, and old gold and has combined them to color the Iris we know as Quaker Lady, and the Iris enthusiast thanks nature for the beauty of this flower, and he also thanks the originator for the very appropriate name. After you have once seen it, you cannot help thinking of a Quaker Lady of the old school every time you see the bloom.

7.5-QUEEN ALEXANDRA (Barr) S. fawn, shot with lilac; F. lilac, reticulated bronze at base.' Beard yellow.

QUEEN CATERINA (Sturtevant)

This fine variety comes nearer to being in the same class with Mother of Pearl than any other variety we know. The colors are somewhat similar and both are excellent.

QUEEN OF MAY (Salter)

A light lilac-pink variety which is very popular in the middle west.

ROBERTS, GLADYS (Perry 1921) Very distinctive. Large flowers. $\mathrm{S}$. bright rose-mauve lined purple; F. light rosy-violet.

ROTA (G. \& K. 1926)

RHEINGAUPERLE (G. \& K. 1915) 1.00

RED GLORY (Fryer) T. B S. bronze-yellow; $\mathrm{F}$. velvety-maroon. Orange beard. Fragrant.

7.8-RED CLOUD (Farr 1913) T. B. S. rosy-lavender-bronze; $F$, velvety-maroon-crimson, reticulated yellow; old gold stigmas; 24-inch.

RED RIDING HOOD (Koehler 1922)

A near approach to red. S. reddish-lavender; F. purplish-red with mottlings of brown near base. 32-inch.

REGAN (Hort 1920) A fine and distinct dark purple. early flowering bicolor with exceptionally long falls heavily reticulated brown on a white ground.

8.4-RHEIN NIXE (G. \& K 1910) S. white: $F$. violet-blue with white margin. The finest of the older Amoenas and a great favorite. Over 3 feet.

8.3-RODNEY (Bliss 1919) A free flowering Dauphin's violet pallida, smooth textured and finely shaped. Tigorous, to 39 inches.

8.0-ROMEO (Millet 1912) S. citron-yellow: F purple, lilac at center. Unique coloring.
8.2-ROSEWAY (Bliss 1919) Phlox-purple, falls duller. Beard orange.
Tery rich coloring. Vigorous, to 42 -inch. in excellent landscape variety; early.

7.4-RICHARD II (Dykes 1914) Standards white; broad spreading falls deep velvety-purple. Beautiful flowers on a riant of weak constitution.

6.9-ROSE UNIQUE (Farr 1910)_._._._-_.15 An early deep pink.

7.3-ROSALIND (Bliss 1921) T. B. A pink blue self, the standards only slightly lighter than the falls. 3 to $3 \frac{1}{2}$ feet.

RICARDI X IBERICA

RICARDI (hybrida a gr. bleus)

8.0-ROYAL (Capernneor) blue and violet .50

SALONIQUE (Cayeux 1923)

S. creamy-white; F. violet-purple, throat veined white. Strong growing and free flowering. A distinct variety of unusual color.

8.0-SARPEDON (Yeld 1914) A clear toned bicolor. S. soft bluish-
violet; F. hyacinth-violet. Large flowers on slender stems. 3 feet.

8.3-SEMINOLE (Farr 1920) crimson, brilliant orange beard. We crimson, brilliant orange beard. We Iris we have seen. Rich in color and a wonderful effect in mass. Over 2 feet.

8.7-SHEKINAH (Sturt. 1918)

One of the finest of the yellow self colored Iris. Flowers on 3 feet stems, pale lemon-yellow deepening at center. Highly recommended.

8.1-SHERBERT (Sturt. 1918) $\mathrm{S}$. ecru-drab, deepening through cinnamon to purplish-vinaceous; $F$. dahliapurple, lighter at edges. Very effective. Stalks well branched. 4 feet.

7.6-SHERWIN WRIGHT (Koh. 1915) A bright golden-yellow self. Tigorous, 2 -inch.

SAN GABRIEL (Dean) A very large flower on tall stems. The color is a beautiful, lustrous, pinkishlavender. Branching stems, very graceful. Grows exceptionally well in California and the Pacific Coāst section.

8.0-SARPEDON (Yeld)

Large, long flower; S. floppy, soft bluishviolet; $F$. straight-hanging hyacinthviolet; beard white, yellow tipped. It multiplies very slowly.

SAUL (Denis) -

S. golden-yellow: F. maroon with darker veinings at the haft. This variety is of the Colonel Candelot type and by some Iris enthusiasts it is claimed to be better than that variety.

STAMBOUL (Foster)

Sir Michael Foster selected this seedling many years ago and it has not yet been superseded. Its colors are light blue in the standards and rich violet-blue in the falls. STEEPWAY (Scott)
S. fawn, suffused reddish-fawn; F. rosymauve with brown reticulations. Beard orange. Its distinctive characteristics are the rounded shape of the falls and standards, and the soft artistic glow it makes in the mass. 
SUDAN (Bliss) let. This new English variety is in a class with Flamerschwert, the new squalens from Germany.

SUN SET (Denis 1919) oold; F. of the same tone tinted bluelilac and violet. Pretty and distinct colour. Vigorous. Late.

8.5-SWEET LAVENDER (Bliss 1919) --.-S. pale lavender; F. horixontal, very broad, widely expanded and of a deeper rose-lavender. The general effect is a lovely shade of rose-mauve. One of Bliss' finest seedlings.

\section{3-SOUV. DE MME. GAUDICHAU} purple. Large flowers of exceptional substance on stalks three feet high Grows vigorous. One of the most beautiful.

7.9-SWATARA (Farr 1918) Standards blue with an undertone of yellow; F. violet. Conspicuous orange beard. 30 -inch.

8.4-SINDJKHA (Sturt. 1918) An Iris of very fine quality; a combination of subdued lavender and buff beautiful, and a proved favorite with garden visitors; 4 feet.

7.3-SYPHAX (Bliss 1917)

S. pale violet; $\mathrm{F}$. deep velvety-crimsonviolet. 30 -inch.

SNOW QUEEN (Orientalis) Large ivory-white flowers.

SHAW, E. C. (Farr 1919) 'T. B. shaded black. Fragrant; distinct; 24inch.

7.7-SHALIMAR (Foster 1916) T. B. Rich violet-purple. Well branched and of fine size. A Trojana seedling. 40-in.

SPLENDOUR (Sturt. 1921)

An engaging flower with ruffled flaring falls and red-purpie tones of extreme depth; 30 -inch.

SOLEDAD (Mohr 1922, Sturt. 1924) A telling, clear yeliow, early flowering, and deeper in tone than most of the Intermediates; 2 feet.

STERN, MRS. F. (Perry 1924) T. B. An extrenely pretty early flowering variety; slender spilkes well furnished with riedium sized flowers. S. light rose; F. brilliant rose.

7.4-TAMERLAN (Vilm. 1904) Standiards lavender and falls violet-purple. 30 -inch.

7.5-TINEAE (origin unknown) Tuch like pallica dalmatica. Very heavy glaucous foliage; pale lavender flowers of typical pallida form on 40 -in. stalks.

TOREADOR (Cleveland 1920)-..--.--.-Siandards bright bronze-yellow; falls red. Sirong grower and free bloomer 30 -inch.

7.5-TREGASTEL (Milet 19-) A red purple bicolor heavily shot with yellow. 30 -inch.

8.2-TRISTRAM (Bliss 1919) Standards white; fails velvety-purple. A most pleasing color contrast. 30-inch. Not as tall as Rhein Nixe but more richly colored, with broader falls than Thorbecke, though with more reticulation toward the haft.
S. bronzy-yellow; F. deep carmine-vio(Same as Ochracea-Coerulea) S. old

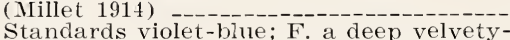
S. light claret; F. claret, veined and
8.4-TROOST (Denis 1908)

Flowers of old rose; very good in spite of the streaking in the falls. 2 feet.

8.5-TARTARIN (Bliss 1919)

Enormous flowers of pale lilac and lavender-violet. The blossoms are huge and beautiful.

8.0-TOM-TIT (Bliss 1919) A gay little deep blue purple blossom; another variety for the front of the border; 18-inch.

8.2-TRISTRAM (Bliss 1919) White and velvety-black-purple; well branched; similar to Thorbeck but of good growth; 3 feet.

TROADES (Perry) $\mathrm{S}$. old rose overlaid bronze; $\mathrm{F}$. bright red-violet edged old rose-bronze. Brown reticulations at base. Good medium sized blooms.

THOMAS, AMY BRANDON (Perry) (Cypriana $X$ Pallida)-One of the most attractive, stout branching stems bearing a profusion of attractive flowers of great substance; standards soft violetblue, while its massive falls are a delightful shade of soft purple, with a conspicuous white lined base with soft brown markings; late flowering.

TERIAS (Longfield 1925)

Best described as a pink Quaker Lady. Flowers of medium size of a peculiar pink. Distinct and beautiful. Very free

7.4-TROBRIDGE, LEWIS (Farr 1913) S. bright violet; F. blue-violet, shaded rose, very large flower, with wide standard and falls; 33-in.

TRINIDAD, MONS. (Denis 1911) $-1.50$ S. aconite-violet; F. Nigrosin-violet; brown-buff center.

TAIT, MRS. A. W. (Fryer)

THECLA (Longfield 1925) -_-_-_-_-_-_----- 1.00

A healthy vigorous Iris, bearing its beautiful flowers in the greatest profusion. Standards bright, clear mauve; the spreading falls purple. Medium size blooms on 30 -inch stems, Most like Cordelia and Monsignor, but freer, and of more pleasing form and brighter color. Especially good in mass or clump.

TINLEY, MRS, (Bliss)

Large flowers of an intense self violetblue, with a characteristic golden blotch.

TELEMUS (Perry) T. B. Fine combination of colours. S. light apricot, overlaid pale bronze; F. bright madder-crimson, white base reticulated chocolate. Tall branching stems, exceptionally
large open flowers. S. broad slightly incurved, brilliant shade rose-mauve; F. broad, standing at right angles, rosecrimison; bright orange beard.

8.3-UTE CiHIEF (Farr 1920)-
Alnost identical with Alcazar, but Almost identical with Alcazar, but ger. An excellent seed parent.

VELOUTE (Vilm, 1924) Best described as an improvement on Monsignor. Of the same coloring, but without the undesirable veining on the falls of that variety. A clear toned purple bicolor of real merit. bloomer. 3 feet.

TITUS (Perry) T. B.

50 
UNDINE (Koehler 1922)

$S$. deep lavender; F. velvety-purple.

8.0-VIOLACEA GRANDIFLORA

A large violet self of smooth glossy texture. Very vigorous and free flowering and an excellent landscape variety.

VINGOLF (G. \& K. 1925)

S. dull cream; F. violet-blue.

VARIEGATA AUREA (Denis) T. B. yellow 1.00

WHITE QUEEN (Perry 1918) Snow-white with beard and throat greenish-white. Very free flowering and vigorous. Will make a fine landscape variety.

8.3-WHITE KNIGHT (Saunders 1916)_-_- .40 Absolutely snow-white: sweetly scented and of fine form.

7.3-WINDHAM (Farr 1909)

An attractive veined pink, somewhat like Her Majesty, but lighter. To 30-in.

8.9-WILLIAMSON, LENT A. (Williamson 1918) T. B.

Massive in growth, stalk and flowers deep red-violet, shaded with yellow toward center. 42 -inch.

7.8-WILLIAMSON, MARY (Wmsn. 1918)-- 1.25 A charmingly ruffled flower, white with a hyacinth-violet center to the falls. 33-inch.

7.3-WALHALLA (G. \& K. 1908) Lavender and plum.

7.2-WYOMISSING (Farr 1909) T. B. S. creamy-white, suffused delicate soft rose; $\mathrm{F}$. deep rose base shading to fleshcolored border. Strong and free flowered. Effective in mass; 24-inch.

\section{0}

WELD, J. C. (Perry 1924) T. B.

Ricardi X Alcazar seedling; tall branching stems, large open flowers; $S$. light rosy-purple; F. brilliant crimson-plum, shaded violet-brown hase. Renarkably effective; very late flowering.

YELD, GEORGE (1923)

This is one of the finest Iris which Perry has produced. It is absolutely a new combination of colors and is magnificent and absolutely distinctive. Stout branching stems bear large well shaped flowers. S. bright apricot shaded rose; F. brilliant rose-crimson, edged buff.

YELLOW HAMMER (Denis 1921) T. B...-- 1.00 Golden beard. The finest primrose self and the first tall yellow to open.

ZILIA (Perry 1924) T. B. Strong growing variety; stout branching stems. bearing large well shaped flowers. S. and F. uniform shade of dark lavender-blue, overlaid rose, very pretty.

ZOUAVE (Vilm. 1922) S. white veined lilac; F. dotted Mansanese, violet edged

7.5-ZUA (Crawiord)

This Iris is in a class all by itself. Its color is nearly white, the bloom is of good size, although it does not grow on tall stems, but its great attraction is the crimped effect of the petals.

8.5-ZWANENBURG (Denis 1909) S. deep cream-yellow; heavily striped maroon; F greenish-yellow with conmaroon; F. greenish-yellow with conand free bloomer. Fascinating.

\section{IRIS COLLECTIONS}

We can offer some wonderful inducements in collections of Irises, if you will leave the selection of varieties to us. The reason we can afford to do this is that in a collection as large as ours, almost a thousand varieties, covering eleven miles of beds, frequently the time taken in digging and putting up the order is worth as much as the value of the plants themselves, and in putting up our own selection, we can put up ten or twenty while putting up one of the other.

Frequently we will have a surplus of some choice or valuable variety, which we can add to our collections in order to balance our stock.

We sent out several hundred of these collections last year, ranging from ten to 100 varieties in each collection, and have many letters from customers expressing their satisfaction and thanks for our liberality.

Please note that in putting up these collections we send out no trash or discarded varieties. Every variety will be tagged with copper-wired painted white pine label.

Please note also that all these collections are sent prepaid anywhere in the U. S.

Ten varieties, all labeled, for Three roots each of 10 varieties, for

Twenty varieties, all labeled, for-_-_-_--- 2.00 Three roots each of 20 varieties for

Thirty varieties, all labeled, for --_-_-_-- 4.00

Three roots each of 30 varieties for.-.-- 10.00
Fifty varieties, all labeled, for-_-_-_-_ 9.00 Three roots each of 50 varieties, for--_--- 22.50

Seventy-five varieties, all labeled, for-_-_-- 15.00 Three roots each of 75 varieties, for

One-hundred varieties, all labeled, for Three roots each of 100 varieties for

We guarantee that the list price of plants sent in these collections will be at least 50 per cent more than price charged. 


\section{FRENCH IRISES.}

The following new French Irises are growing in our gardens, and we expect them to bloom this spring. None of these are for sale this year.

\section{L.ABOR.}

AZIRADE.

PHRTNE.

SOLFERIXO.

CARDINAL (Bliss).

GERMIANE PERTHUIS.

LE GRANDE FERRE.

LOUIS BEL.

\author{
SENSATION. \\ OPHELIA. \\ GLORIAE. \\ MME. HENRI CAYEAUX. \\ SOUTENIR DE LOTITIE \\ MICHAUD. \\ TROUVAILLE.
}

MLLE. JEANNE BEL. RENEE DE LABORDE. HYBRIDE DE BLANC BLEUTE. LIONESQUE. JACQUELINE GUILLOT. MME. ABEL CHATENAY.

The above are quoted by the few dealers who list them for sale at prices ranging from $\$ 10.00$ to $\$ 100.00$ each.

If you are not in a hurry, we expect to work up sufficient stock, that within two years we can sell them for one-tenth those prices. 


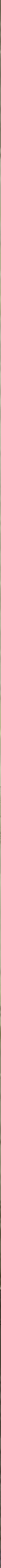




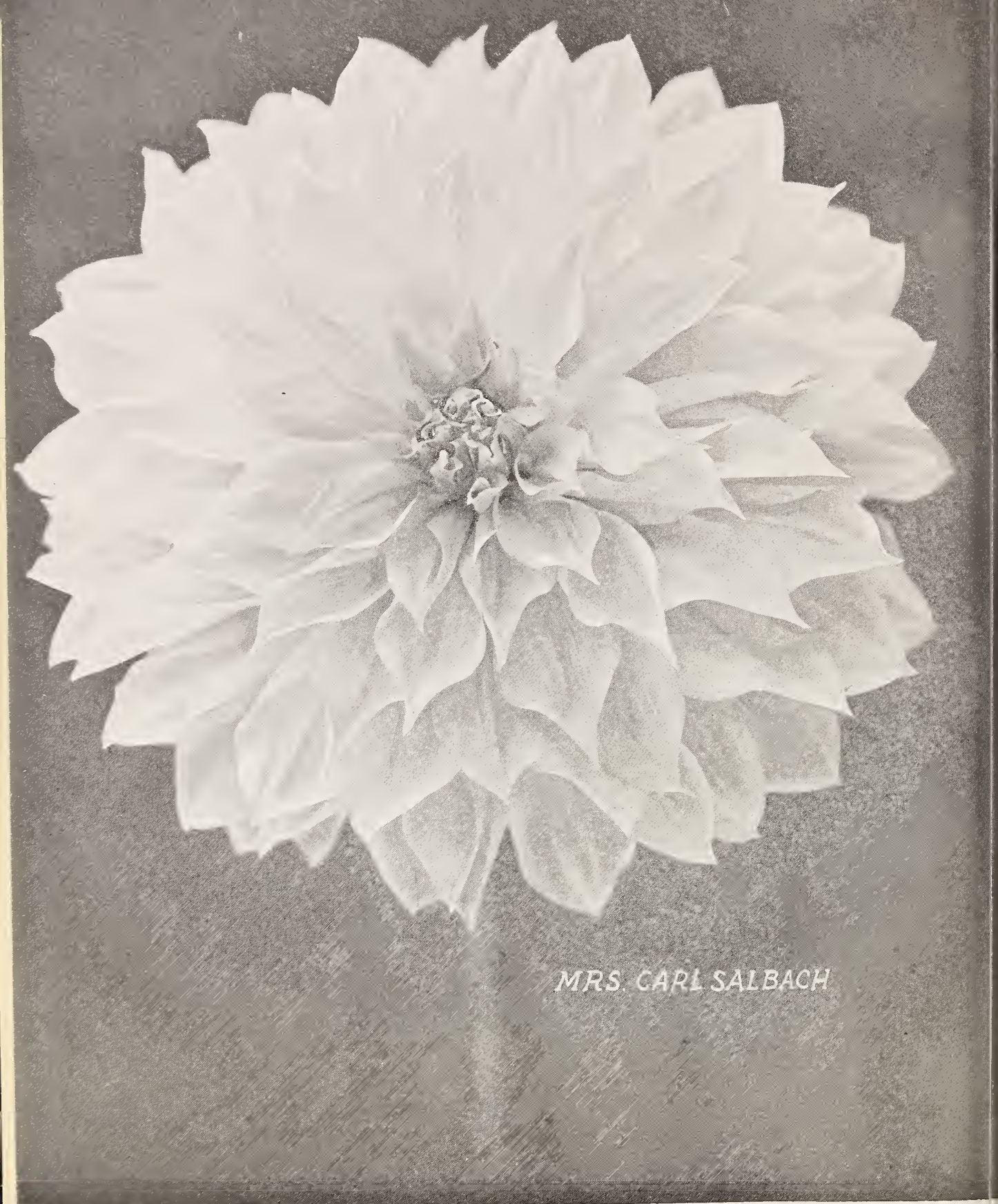




\section{PLANTS THAT GROW AND BLOONI}

\section{THE DAHLIA}

In our first catalogue, issued two years ago, we listed and descriked 238 varieties of Dahlias, including some novelties costing as high as $\$ 25.00$ each.

That same year throughout the entire Southwest, the Dahlia season was a failure and disappointment, an early freere killing plants, so there was no fall bloom.

Last year we did not list Dahlias, but grew about 100 varieties in our gardens and had fine success again, and took careful notes to see which were the most satisfactory and this year we are listing but 42 varieties, but believe they are the 12 best in the world, at a moderate price, and you cannot go wrong buying any of them, and if you want a fine collection, will sell you the entire list of 42 in strong tubers amounting at regular prices to $\$ 45.00$, for $\$ 35.00$.

Of this list the last ten are new European varieties, recommended highly, which we have imported from Holland along with about 50 other European novelties which we will try out this year before offering for sale.

Many of these have won cups, and medals in recent European shows, and all have certificates of merit from the Nederlands Dahlia Society, and we expect something sensational this fall when they should be at their best.

All flower lover's are welcome in our gardens and we will be delighted to have you share the beauty of these new Dahlias, the elite of the French, Dutch and English growers, with us.

We are giving brief instructions on how to grow Dahlias. Do not plant until the ground is warm. May in this locality and June further north, is the proper time.

If possible, plant in an open, sunny situation. Prepare the soil thoroughly by deep digging. Be mocerate in the use of both manure and water. Never plant when the soil is wet. Lay the tuber flat on its side and cover it four inches deep, pressing the soil firmly on the tuber. Keep the soil loose and mellow by frequent hoeing, drawing the soil to a slight hillock around the plant.

Tall growing varieties may be kept fairly dwarf by pinching out the tip when the first shoot is six inches high. All varieties growing above four feet should be tied to stout stakes to hold them in positicn.

$3 \times 3$ feet is about the proper distance to plant apart.

Keep all dead flowers trimmed off.

Dahlia blooms keep much better if cut in the evening--about sunset-and the less foliage taken off with the flowers, the better for both plant and flower. If green is desired, use some other green of better keeping qualities.

After frost has killed the tops, dig the tubers carefully, remove the soil from the roots, and store away in a box or barrel secure from frost. As a precaution it would be well to cover the tubers so stored with sand, leaves or moss.

All clumps should be divided into several pieces before being reset the following spring.

AMBASSADOR (Broomall) H. Cactus

The sensational dahlia since its intro-

duction in 1921. Notwithstanding many

great new introductions since then it

still stands supreme as the best and

most artistic dahlia. Color, soft yellow

center with salmon-amber and pink shadings, gradually deepening toward the tips, and outer floral rays. The blending of these colors is captivating. The flowers are the largest and set just right, on perfect stems. Strong grow$\mathrm{er}$, free bloomer and good keeper. 


\section{AMUN RA-THE EGYPTIAN SUN GOD}

"And each is covered with copper ard gold, and shall be seen from untold distances, and the land shall be flooded with their rays of light."

(From an ancient Egyptian papyrus.)

AMUN RA (Seal) -

The great Gold Medal Dahla is still a leader, having again won throughout the entire country. This immense decorative, resembling a glorious setting sun, is a mystery in color and unlike any color combination known in dahlias. The outer petal of the mammoth blooms are of gorgeous shades of copper and orange, shading to bronze and amber, and deepening in the large full center, to a rich, dark, reddish bronze. This new metalic coloring appeals to all, as it is a color so generally in demand at the present time. A well known artist gave this description of Amun Ra: "The glint of a topaz that is placed near a bit of old Chinese Lacquer would suggest the tone of Amun Ra. To call it a glorified burnt orange hardly does it justice." The stems are wonderful-erect and stout and hold the immense blossoms well above the strong vigorous plant. The blossoms keep for days when cut and last indefinitely on the bush. Anuun Ra will be in flower long after many of the other dahlias have ceased blooming.

BALLET GIRL

Very large cactus with long very finely quilled petals. Color, orange tipped white; some flowers solid orange on same plant. BASHFUL GIANT-D. (Marean)
Gigantic exhibition blooms. Apricot with golden shadings.

CHAMPAGNE (Bessie Boston)------ - 2 - 2 Is a large Dahlia, but size, while a strong feature in a Dahlia, is not everything. This decorative seems blessed with all the Dahlia qualities to make it a success. Color is delightful, warm autumn shades, varying from burnished copper to a dull golden champagne and chamois. Stem is heavy and holds the massive flower absolutely upright, and the bushes are plentiful producers of blooms. This decorative has always been a prize winner.

CHILDS, JOHN LEWIS-D. (Boston) One of the best fancy novelties. Yellow, suffused, splashed and striped with brilliant scarlet, and generally tipped white.

COUNTESS OF LONSDALE-C

One of the best bloomers of the cactus type. Deep salmon-red and greatly admired. We have a large stock.

DRESSELHUYS, MR. C. H. While the color is not so good as Delice, it is a more vigorous grower producing the soft rose-pink blooms freely on long stiff stems. It will be grown by those who do not have success with Delice.

DUNLAP, KITTY-D. (Bessie Boston) ---Blooms all season and keeps well, has long, firm stems. In color like the American Beauty rose.
DURNBAUGH, DOROTHY (Cactus) Very large rose-pink flowers on long stems.

DR. FELLOWS-C. (Stredwick) One of the best cactus Dahlias. The lalge orange to terra-cotta blooms are produced profusely on good wiry stems. Splendid for exhibition and cutting.

JERSEY'S BEAUTY-D. (Waite) In a class by itself. A perfect bloom of Erosine-pink, carried high on perfect stems. Awarded many prizes and medals, and one of the best for cutting and exhibition.

JERSEY'S KING-D. (Waite) Immense carmine flower, toning to old rose. Fine grower.

JEAN CHAZOT-also called GAY PAREEH. C. (French var.) An autumn tinted cactus Dahlia; the color is a golden-bronze, suffused nasturtiam-red. Extremely free bloomer.

JUDGE MAREAN-I). C. A wonderful blending of yellow, gold and orange, suffused pink and edged red. LOBDELL, FRANCIS-H. C. (Waite)-----
Mellow pink, shading to white in center, wonderful free bloomer, splendid bedding cut flower and exhibition variety.

MILLIONAIRE-D. (Stillman) Most delicate lavender, with a faint pink cast overshadowing it. Valuable cut flower and has won many prizes.

O'MARA, PATRICK-D. (Vincent) Pale gold or orange-buff colored flowers borne on strong stems. Great cut flower variety.

PRIDE OF CALIFORINIA-D

Crimson-red with dark, full centers. Huge flowers on long straight stems. Excellent for exhibition and a fine cut flower.

PIERROT (Cactus) Immense size with very long incurved petals; deep amber, distinctly tipped white, sometimes solid amber. A magnificent exhibition and garden variety.

ROSA NELL-D.

Mr. Broomall, whose introduction this is described it as the greatest of all decorative dahlias. Large bright rose flowers of good shape, on fine strong stems. Fine for exhibition or cutting.

SALBACH, MRS. CARL-D. (Salbach) --A favorite flower in all sections, that created a sensation when introduced. Color is a lovely shade of mallow-pink, produced in great abundance. Has many medals, cups and other first prizes to its credit.

SEAL, MRS. JESSIE-P. (Gleadell)-----The large blooms of beautiful old rose stems. Vigorous grower and free bloomer.

SPENCER, MRS. EDNA-H. C. (Spencer)-- .75 Color an exquisite lavender-pink, nearest to an orchid shade of any dahlia. Splendid form and size and fine cut flower. 
SMITH, MRS. J. P.

A vivid cherry blush over a rich crimson. The largest show dahlia. Introduced 10 years ago and still best red show in the world.

SCARAMOUCHE

This is a very fine American cactus on long, strong stem and is a good cutter and keeper. Nopal-red, shading a trifle lighter at tips.

SWEETBRIAR (Cactus)

An exquisite shade of pink. Always a mass of flowers, standing well above the foliage.

TEVIS, DR. H. C.-D. (Pelicano) A famous prize winner. Large old gold and rose flower on perfect stems.

TREAT, ROBERT

The American Beauty colored dahlia. A strong, vigorous grower and free bloomer. Beautiful form and large size.

WARNER, MRS. I. DE VER-D. (Marean) 1.00 One of Judge Marean's best creations. Large, beautiful rosy-mauve flowers of fine form and substance, on long, rigid, stems. One of the best for exhibition and for cutting.

WALTERS, GEO. (Cactus) Flowers of immense size. Color a rich coppery old gold, tinting to buff at the center. A great acquisition.

THE NEXT TEN DAHLIAS ARE IMPORTATIONS THIS SEASON:

ADLER-D. (Ansorge) A. M. Haarlem 1925. Undoubtedly the largest pure white Dahlia raised. A grand show variety. The immense flowers are carried on strong, long stems.

AUGUSTINUS-D. (Older 1920) A most wonderful colour combination of lilac-rose and yellow. Immense flower on long, strong stems.

GLOIRE DE STAMHUIS-D. (Waveren '20) 1.00 A. M. Amsterdam 1921, Haarlem 1922. Dahlia Trials Haarlem 1922 . Colour burnt amber, real autumn tint. Well- formed flower, horizontal on a long, elegant stem.

MENSING, JOHAN (Dec.) (Topsvoort'24) 2.00 Winner of the Challenge Cup at Leyden 1924. A. M. Dahlia Trials Wisley 1926. 1 st Class Cert. Amsterdam and Haarlem 1924. A. M. Dahlia Trials Haarlem 1923. Deep crimson-scarlet, well formed flowers on exceptionally long, stout stems.

GALBAN, MAD. JULES (Cactus) (Nag. '23) 1.00 Brilliant orange-red, changing into yellow and even into white. A remarkable variety.

KROON, MRS. (Kroon 1923) --_-_-_-_-- 2.00 1st Class Cert. Amsterdam and Haarlem 1924. The remarkable star-shaped flowers are of a bright cinnamon colour, with deep orange centre, decidedly pretty. Stems long and wiry. Freeflowering.

MURILLO-DDec. (Glasbergen 1922) -_-_-_-_- 1.00 1 st Class Cert. Haarlem 1922. A. II. Dahlia Trials 1922. An exquisite variety. One of the finest pink Dahlias ever raised. Colour flesh-pink with a rosy-salmon shade. The flowers are regular in shape and carried on long, elegant stems. Free flowering.

MY LADY-D. (Kroon 1923) 1.00

A. M. Amsterdam and Haarlem 1923. A wonderful variety admired by all ladies on account of the most pleasing colour combination. The colour is dove-grey with amber shade. Flower stalks are long and wiry, free above the foliage.

KOOY, MRS ENSCHEDE-Dec. (1924) -.--- 1.00 Selected for Trial at Wisley $192 t, 1$ st Class Cert. Amsterdam and Haarlem 192t. Colour a glowing orange with terracotta centre. Flowers of medium size and perfect form. Long and wiry stems. Highly recommended. Free flowering variety.

WHITE QUEEN (Kroon 1919) 1.50 Pure white, flowers on long and elegant stems. Very free flowering. Highly recommended by everybody who has grown it. 


\section{FRENCH LILACS}

The lilac has long been a favorite shrub in the American garden from Colonial times and at Mount Vernon as well as at many of the famous old homes of New England fine specimens of lilacs, almost of tree-like proportions still yield their beauty and fragrance long after those who planted them have passed beyond. It is said that Longfellow and Nathaniel Hawthorne would never let any business call them away from their country homes while the lilacs were in bloom.

The old fashioned or common lilac had to attain considerable age before blooming, and in transplanting it also took its time before adjusting itself to the new location. Lemoine, the great French hybridizer, has given us a new race of lilacs where this objection has been overcome. Not only do they usually bloom the first year after planting, but unless you see them, you can hardly realize the wonderful improvements made in these crosses. Giant trusses of beautiful flowers, many of them double and a range of colors varying from white and creamy white to soft shades of pink and rose, soft blues, violets and heliotropes, deep purple crimsons and dark purple garnet.

They are best planted in the fall but spring planting is satisfactory if done early, though they seldom bloom the same year.

Lilacs are fine for specimens or in the shrubbery border. Many fine collections can be made and we know one grower who has 200 varieties and still adding to it. The plants we offer are budded or grafted very low on privet; they will quickly get on own roots after transplanting providing the union is placed about four inches below the surface of the ground. These plants are from two to three feet in height.

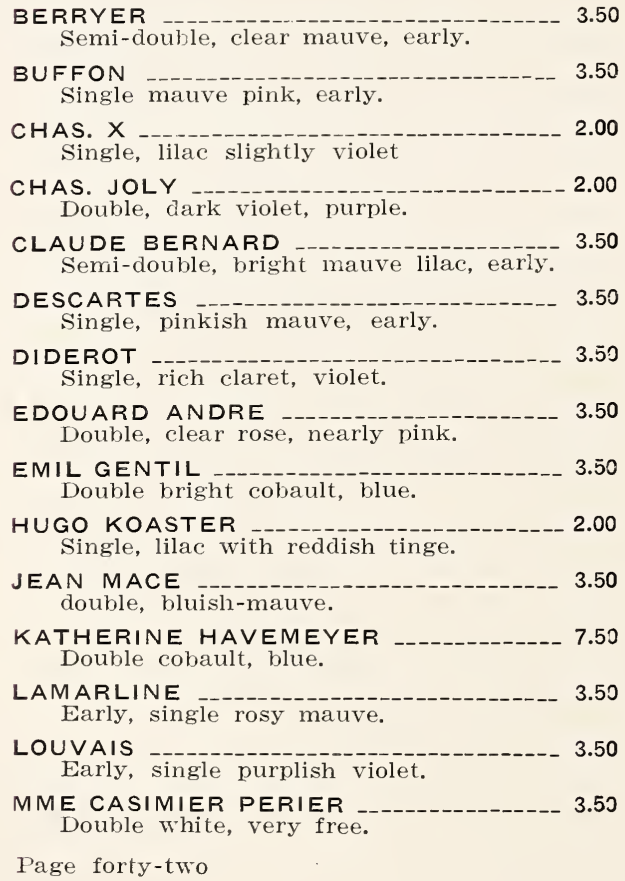

Page forty-two

MME LEMOINE Double white, very large.

MARIE LEGRAYE Single pure white, very free.

MICHAEL BUCHNER - 2.00 Double, pole lilac.

MONT BLANC --.- 3.50 Single pure white.

PASCAL - Single, typical lilac, very free, early.

PRES. GREVY _._. Double blue.

PRES. LOUBET - 3.50 Dou le purplish lilac.

REAUMUR - 3.50 Single, violet carmine.

SOUVENIR DE LOUIS SPATH Single purplish violet.

VAUBAN

Double, tender maure, early.

VESTALE Single, pure white.

JAN VAN TOL _-_-_-_- 6.00

This variety was universally admired at London, Paris and other flower shows. Hhis is the finest white lilac, having larger trusses, larger individual flowers than any other. It also grows freely and one of the best for forcing.

If you wish some of the common lilacs we can furnish you fine plants 3 to 4 fe. at $50 \mathrm{c}$ each, or $\$ 3.00$ for ten, either of the white or purple. 


\section{RARE SHRUBS AND TREES}

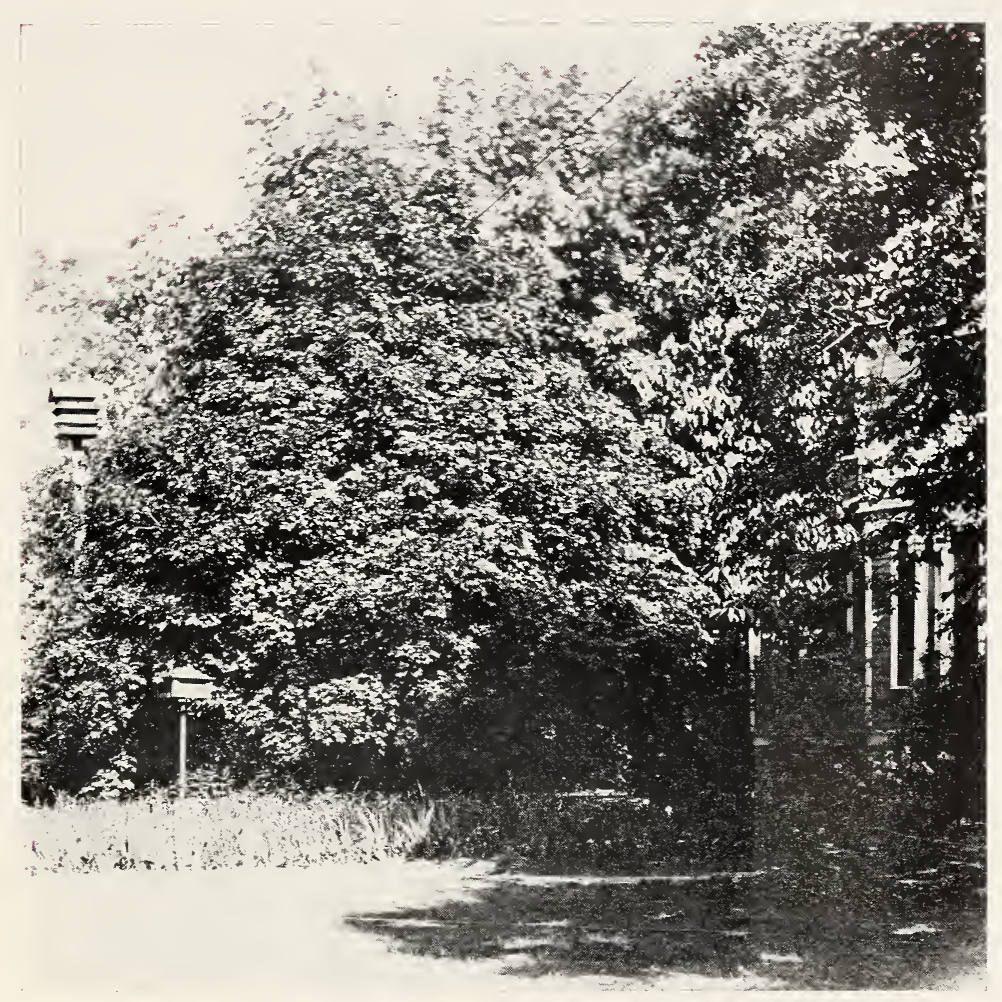

\section{SCHW EDLER'S MAPLE.}

Probably nothing growing in our gardens in the spring receives more admiration than the specimen maple shown in tle above picture. It's botanical name is Acer Schwedleri, and the foliage when it first leaves out is a bright red lile the blood leaved Japanese Maples, and being of immense size (much larger than any of the Japanese Maples get to be) is very striking in eppe-rance. Later the foliage turns a bronzy green, but the tree is very handscma until it loses its foliage in the late fall.

The seed pods, which it bears in abundance, are also very ornamental, being a bronzy red color.

We have several hundred young seedlings of this tree. but they grow slowly, and the demand was so urgent that we have secured some nursery-grown young trees about 3 to 4 feet in height, which we cre selling at $\$ 2.00$ each, or six for $\$ 10.00$.

You can plant nothing in your garden, or on your lawn that will furnish such ornamental value for tle mcney, as these trees.

We are sorry that we will not be able to offer any of our Japanese Maples and Chinese Magnolias for sale this year, as import jegulations will not permit. Some of these Japanese Maples have as many as six colors and shapes of leaves growing on one bush. These Japs certainly have grafting down to a fine art.

We have imported direct from Lemoine of France, and have growing in our gardens six new varieties of Philadelphus, or the Mock Orange, which are great improvements over the accustomed varieties we have been growing, but can only offer one of these for sale this year. 
This is a fine shrub, which we have been growing for three years, and can offer nice bushy specimens. The individual flowers are of largest size, half double, and often a second crop of blooms is produced in the autumn. $3 \mathrm{ft}$ specimens.

\section{A Real Novelty in Shrubs New Red-Leaved Japanese Barberry}

(Berberis Thunbergi Atropurpurea)

It is only once in a lifetime that a really worth while outstanding novelty in hardy shrubs is introduced, and in this new Barberry we have such a plant.

It is similar in all respects to the green-leaved Japanese Barberry which is so popular for mixing in the shrubbery border, as single specimens, or for planting in clumps on the lawn, as well as for foundation plantings and for hedges, but the foliage of this new variety is of a rich, lustrous, bronzy-red, becoming more brilliant and gorgeous throughout the summer and in the fall changes to vivid orange, scarlet and red shades. In this coloring it is unequalled by any other shrub and is followed by the same brilliant scarlet berries common to the type which remain on the plant the entire winter.

In order to develop its brilliant coloring at all seasons it must ke planted in full exposure to the sun.

Heavy two-year old plants, each

Beautiful Speciment plants, three-year old, each

2.50

\section{Lord Penzance's Hybrid Sweet Brier Roses}

These lovely hybrids are crosses between the common Swcet Brier and various other Roses, and like their parent, the foliage is deliciously scented. Perfectly hardy. For best effects should be grown as pillar Roses.

AMY ROBSART-Splendid deep rose color.

ANNE OF GEIRSTEN-Dark crimson of graceful habit.

LADY PENZANCE-Beautiful soft tint of copper with metalic lustre, the base of each petal is yellow.

PRICE-Strong three-year old field grown plants $\$ 1.50$ each; one of each for $\$ 4.00$ 


\section{$\mathcal{F} L O W E R$ SEEDS}

As we wish to grow only the finest things ourselves, and have imported from The Royal Horticultural Establishment of Kelway \& Son, England, seeds of their rarest and most notable perennials for our own use, we will give our customers an opportunity to participate in this purchase, and we are listing the varieties we have to spare.

Instructions are sent with each package for growing plants from these seeds. We are naming Kelway's prices on these seeds; no cdvance in any instance.

\section{THE DELPHINIUM}

is one of those flowers which Kelway \& Son have greatly improved and popularized. They were the first to improve this flower and the varieties we list are absolutely the most advanced and up to date.

This is one of the most beautiful of all flowers and provides a color, blue, of which we have too little amongst flowers. As well as being most rich in coloring, its stateliness of habit is marked.

The Kelways have improved the Delphinium almost out of recognition during the past four decades and the narrow sepals huddled together and hiding their color in rather untidy and hangdog fashion have been succeeded by broad, open, well-set-up flowers which make the most cf their color and shane.

This has keen the result of careful hybridization, combined with selection.

Kelway's price is $\$ 1.00$ per package for seed from all these varieties. Our stock is very limited, but as long as it lasts we will sell these seeds from Kelway's aưvanced Delphiniums at $\$ 1.00$ per package, but to avoid disappointment, would suggest that you allow us to substitute in case we are out of the variety you order.

While they will not come true to description from seed, you are bound to get something very fine from such parentrge as these valuab'e plants, and they are put up, sealed and labeled in Kelway's establishment.

We are giving Kelway's descriptions of the plants and the price which they charge for EACH plant, from which these seerls were taken. Wo are figuring the shilling as $25 \mathrm{c}$.

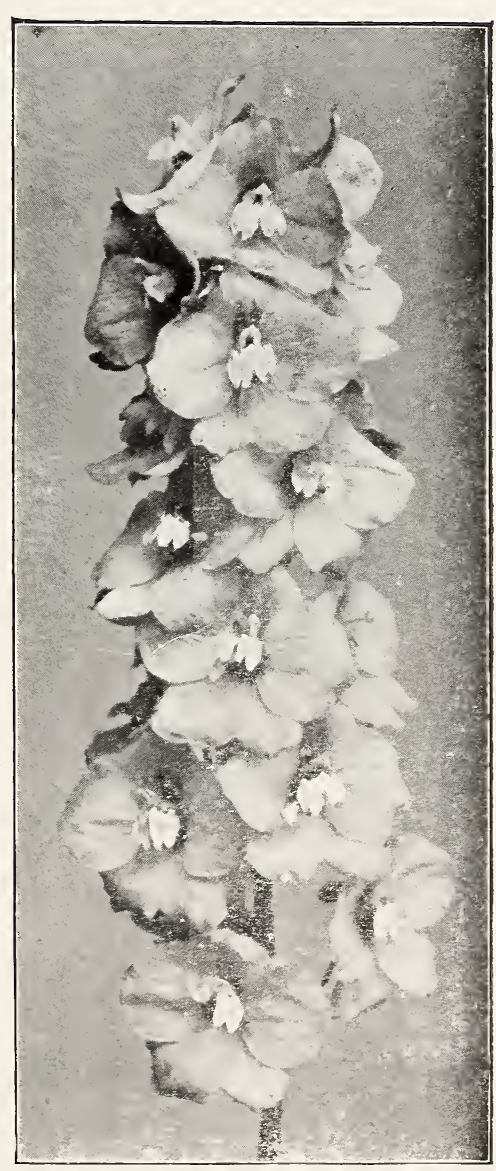


each

with large white eye, semi-double; grand. One of the largest Delphiniums ever raised; tall.

KELWAY'S MAGNIFICENT

Deep violet and richest plum; large white center: very telling; tall; of wonderful richness.

KELWAY'S SPLENDOUR Pale sky-blue and mauve, large brown eye, covered with yellow beard. Early flowering; semi-double; medium height.

COUNTESS OF ILCHESTER

Large; sky-blue with a white center; single flowered; most beautiful. One of the most lovely of all Delphiniums. Absolutely ravishing.

DR. LODWIDGE

Beautiful sky-blue and rose; two rows of petals; semi-double; very fine; general aspect a pretty bright bluish-lavender; dwarf branching habit, but with long flower spikes, 31/2 feet, flowering from one foot.

DUSKY MONARCH

Light purple; very large; two rows of petals; the color of royal mourning, with a striking black center; semi-double: quite distinct; a highly recommended dark variety.

GENERAL MAITLAND

Beautiful clear blue, large white eye; very large pips.

GERALDINE KELWAY

Pale azure-blue; most beautiful; single white eye; very large individual flowers and large spikes; tall.

HUISH BEAUTY

A very distinct variety; lich deep pure blue with a deep purple-red edge, which gives it a very striking appearance. A white center; single; especially good; branching habit.

LORD CURZON Sky-blue, heavily edged pink, black and yellow eye; very dwarf habit.

MONARCH OF ALL

Richest violet and purple; brown eye semi-double; huge flower: enormous spike; tall; grand. One of the best.

MRS. JAMES KELWAY

Beautiful pale siky-blue, with pink inner petals: large white eye semi-double: flower very round and compact. One of the most beautiful Delphiniums ever raised. An enormous spike and flower; tall.

SISTER ANGELA

Light sky-blue, large white eye; single; grand: large open flower. Style of Geraldine Kelway.
SMOKE OF WAR

Deepest reddish-violet and purple with a large black center; semi-double. Nothing like it in lurid color.

STAR OF LANGPORT

Delicate pale sky-blue, large white eye single flowered; very large. One of the very finest and most beautiful Delphiniums ever seen.

CHRISTINE KELWAY

Bright pure sky-blue with a white center; single. In the style of Belladonna, but very much finer, taller and stronger: of branching habit; tall. A resplendant kind, satisfactory in every way.

JAMES WILLIAM KELWAY

Lovely deep blue and plum; large striking white eye: semi-double; flowers measure 2 3-4 inches across.

\section{KELWAY'S MASTERPIECE}

Light reddish-purple, reflexed flowers; eight white petals, inlaid around the inner petals; astounding in its markings and very beautiful; quite distinct; tall.

KITTY WARDELL

Lovely sky-blue; inner petals lavender colored; a nearly double flower of rosette form. Absolutely distinct and most valuable; tall.

LADY FAIRE

Most delicate milky-lavender and sky-

blue; large semi-double flowers with two rows of petals. One of the best. Tall; distinct and most pleasing color.

LITTLE BOY BLUE

Bright sky-blue; cream eye; quite unique; single flowered; nothing like it.

MILLICENT BLACKMORE 1.85

A lovely Delphinium, long spikes of perfect form; pips very large and perfectly placed; color a beautiful combination of blue and mauve.

MRS. CHRISTIE MILLER Splendid shade of cream; the largest spike in this color.

MRS. H. J. JONES A variety of great merit. Lovely Cambridge-blue; extra large well opened flowers. One of the best.

STATUAIRE RUDE Pale heliotrope; large flowers, semidouble. One of the best.

TRUE BLUE One of the very finest: single flowered, intense blue, with black eye. A lovely Delphinium.

BEAUTY OF LANGPORT $-1.25$ Clear soft creamy-white with a pale buff eye; the buds are pale primrose before opening. 5

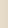




\section{OTHER KELWAY SEEDS}

\section{ANTIRRHIUM}

Maximum "Fairy Tale." This beautiful snap dragon is a novelty which surpasses all others by its very charming color. It is over two feet high and the numerous dense terminal racemes show wonderfully strong blossoms, over two inckes in diameter. The upper lip is salmon-rose; the lower one with light golden-yellow palate and salmon lobes; the tube is whitish. A very showy variety that will become a favorite. Package_-__35c

\section{HOLLYHOCKS}

Kelway's Perfect Model, named double sorts which are very fine indeed and were awarded a Gold Medal, highest prize at the Paris Expasition. Six separate varieties $70 \mathrm{c}$; all colors mixed, package $24 \mathrm{c}$

\section{PYRETHEUM ROSEUM}

Mixed seeds from Kelway's named single kinds; package

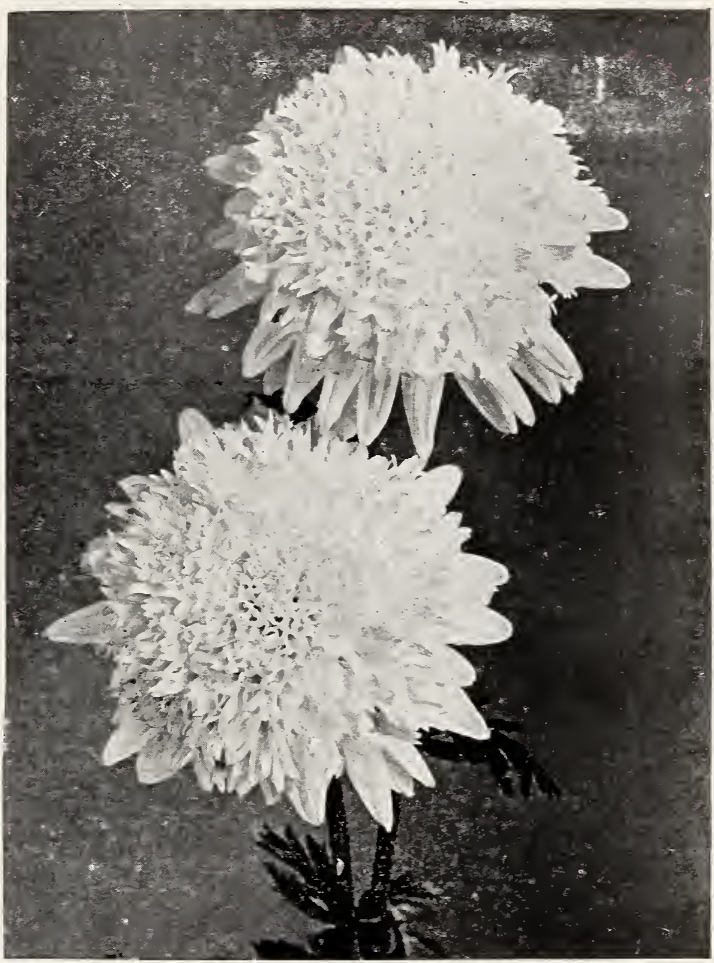

MIXED SEED, saved from Kelway's unequalled collection of named double kinds (see picture) package $-36 c$ 


\section{THE SAM CARPENTER GARDENS}

\section{$Z I N N I A S$}

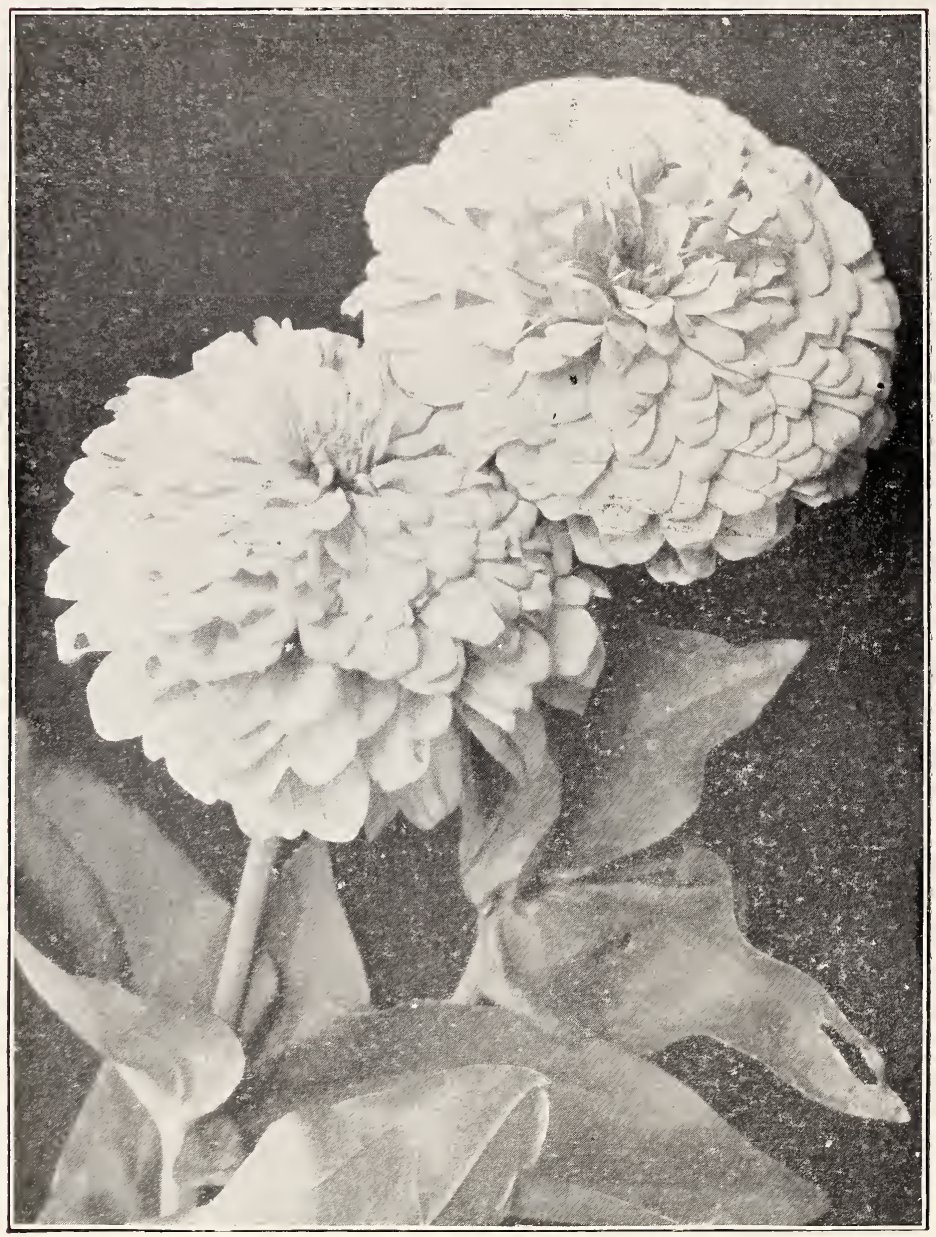

KELWAY'S NEW SUPER-GIANT (package) _ \$1.00 A Dahlia-flowered type that has proved exceedingly popular. Flowers of huge size and beautiful coloring. A great advance on otker strains and strongly recommended. Unsurpassed for cutting. Six separate varieties in packet. All varieties mixed in one package

\section{KELWAY'S QUEEN OF THE SNOWS (pkg.)__24c}

A huge pure white Zennia, which commands attention wherever shown. 


\section{$D U T C H \quad B U L B S$}

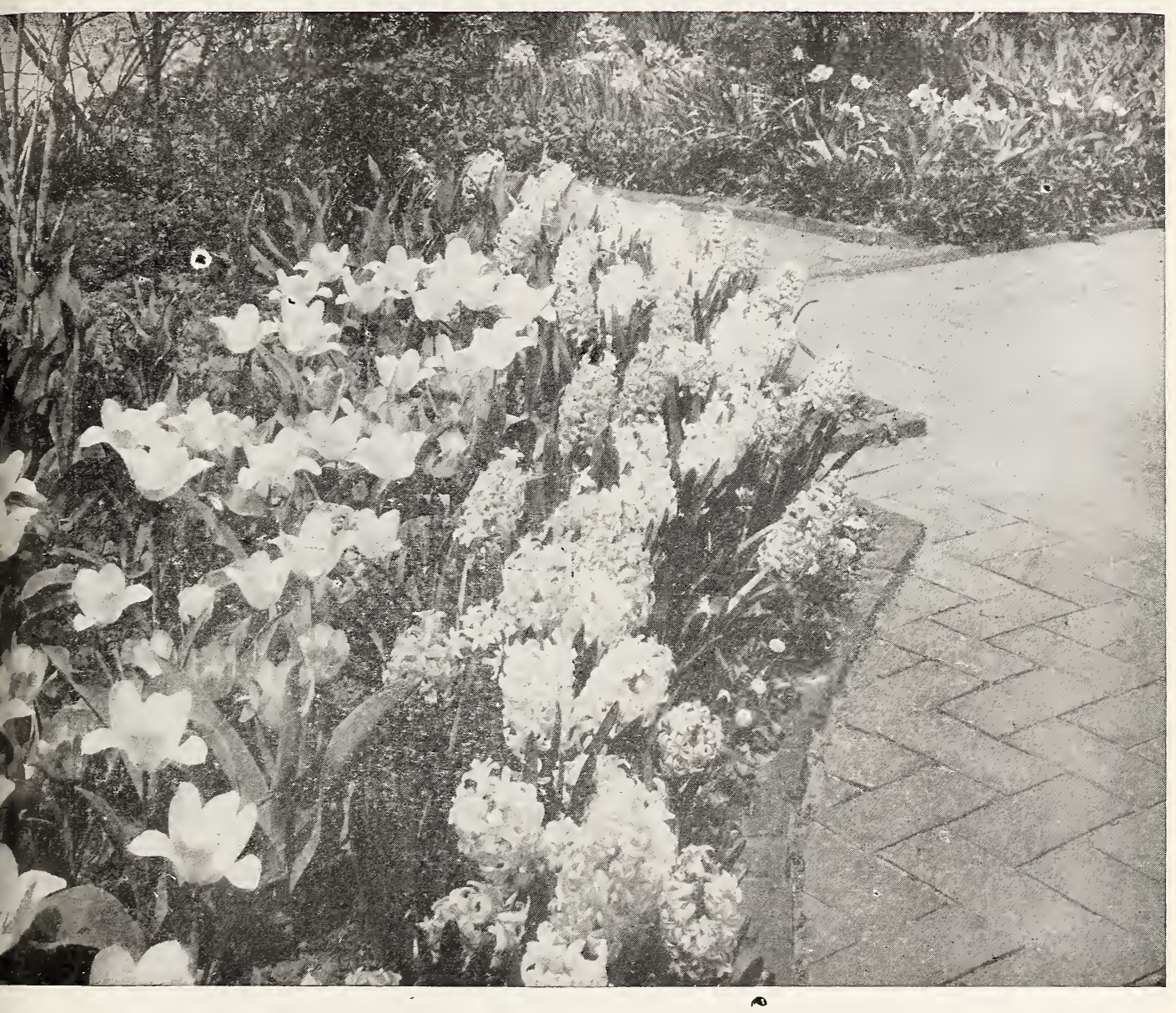

(1) UR OWN representative will personally select these bulbs for us from one of the largest and most reliable growers in Holland. The views we are showing were taken on this farm. No matter where you buy or what you pay, you cannot get better bulbs than we will supply this fall. As some of our stock of the rare varieties is limited, an early order will be appreciated by us and may save you disappointment. All prices on bulbs are f.o.b. Oswego. If desired by parcel post send extra for postage. If you send too much it will be refunded. 


\section{THE SAM CARPENTER GARDENS}

\section{BULBS OF THE HIGHEST QUALITY FOR 1927}

Diagram of Depth and Intervals for out-door planting of SPRING FLOWERING BULBS.

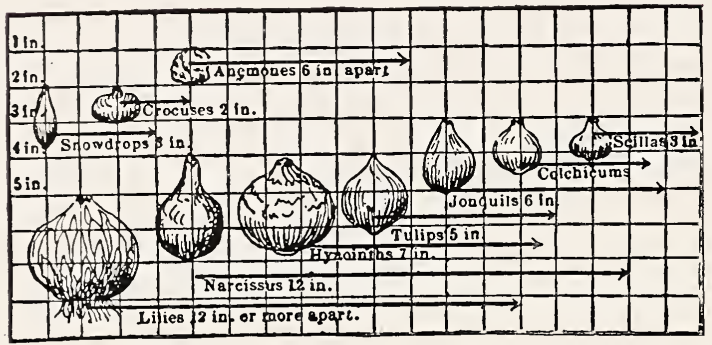

\section{Darwin Tulips}

The Darwin Tulips were developed in the north of France, supposedly from choice varieties of Byblcem Tulips. Owing to the unusual clearness of the colors, to the substance of the petals, and to their vigorous growth, these seedlings, when they came into the hands of the prominent Dutch firms, seemed worthy of forming a new class of Tulips. In 1889 they were named in honor of Darwin, and offered for sale. They remained little known for a number of years, but with the renewed interest in the Tulip, which sprang up in England at the beginning of the pretsent decade, they commenced to receive attention and their popularity here promises to exceed the favor they have enjoyed so long in Europe.

The color's include the brilliant scarlets and crimsons, and the more somber tones of red. The shades af rose and pink, of violet and purple are unsurpassed for their delicacy or their richness of color. There are slate blues and blueviolets which might almost be called blue, while Dumas" "Black Tulip" is very nearly realized in some of the dark maroon varieties. There are no yellows. All the bronze and buff tones are Breeders; while bright yellow and orange-scarlet must be sought among the Cottage Tulips. The Darwins may be left undisturbed for two vears, but it must be kept in mind that Tulips are not long-lived in our soil and climate, but if taken care of, we have known them to last ten years. The collection offered in this catalog is made up from the best varieties offered for sale in Holland. All have been tested at The Sam Carpenter Gardens and we stand behind each one of them.

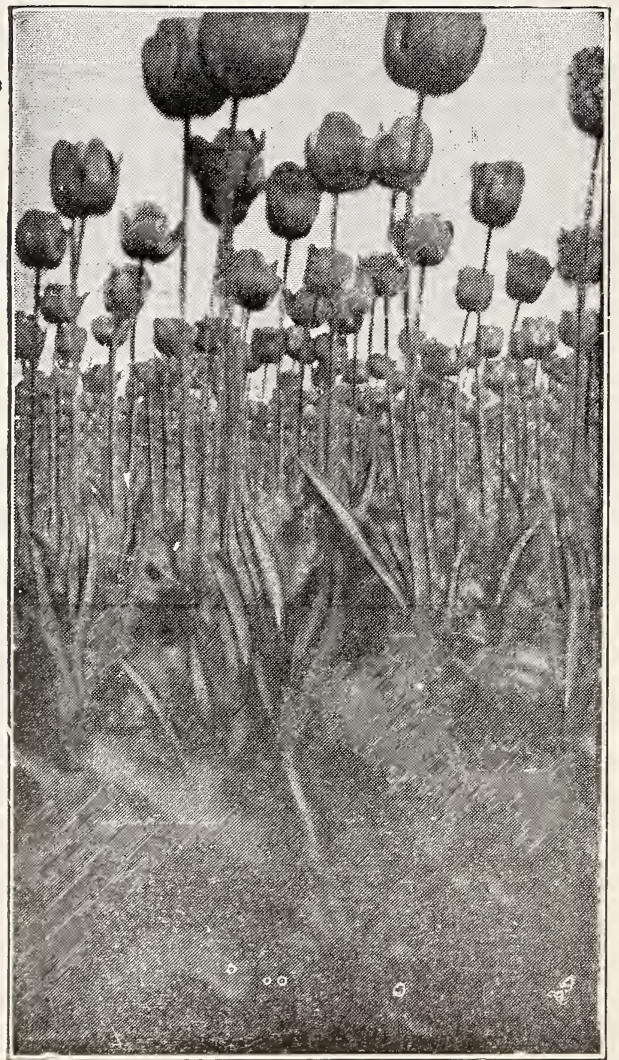

The figure following the name indicates the relative time of flowering.

10100 Bulbs Bulbs

AFTERGLOW; syn., KATHERINE HAVEMEYER. 4 Deep rosy-orange, with sal-

mon shading at edges of petals; inside deep orange with yellowish base. A showy

Tulip for outdoors. Height 26 inches. 
APHRODITE. 3. Silvery rose-pink, white base. Height 34 inches_-_-_-_-_-_-_-_\$1.50

ANTON MAUVE. 2. Clear violet, edged light violet. Extra large flower, very

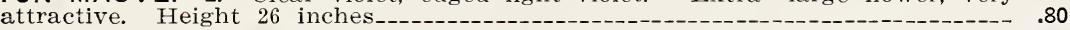

BARONNE DE LA TONNAYE. 4. Bright rose, margined bluish-rose. Height 26-in. .45

BLEU AIMABLE. -4. Pale lavender with white base, starred blue; beautiful flower of distinct shape. Height 25 inches.

BARTIGON. 1. A very Showy, shapely flower of good substance on strong stem; fiery crimson with pure white base, broadly ringed deep blue. It is splendid for forcing. Height 28 inches.-_._-

CENTENAIRE. 1. Rich violet-rose, with large blue base; enormous flowers. Early. One of the best forcing varieties. Height 30 incres._.

CITY OF HAARLEM. 3. Intense dark scarlet, with darker bloom; large steel-blue base and white halo; wonderful ffower. Height 27 inches.

CLARA BUTT. 4. Clear pink, flushed salmon-rose; inside much deeper, with blue base. Beautiful out-of-doors. Height 21 inches_._.

CREPUSCULE. 3. Lilac-white, with dark rosy flush at tips of petals. Large flower. Height 28 inches._-_-_._.

DREAM. 2. Pale heliotrope, inside deep violet with blue base. Height 27 inches--

DUCHESS OF HOHENBERG. Most lovely association of gray-lilac and rosy-heliotrope. A magnificent flower of perfect form, borne on a stiff stem. Makes lovely beds with white Violas. Height 29 inches.

FEU BRILLIANT. The most glorious scarlet Tulip ever raised; large and beautiful shaped flower on strong stem; one of the first to bloom; highly recommended. Height 28 inches.

RANS HALS. Violet-blue, large flower. First class. Certificate Amsterdam. Height 25 inches. - 80

HOMERE. Fine bright scarlet; earliest of all red Darwins

JUBILEE. 3. Blue-purple with white base. Huge flower. The finest Darwin of this color. Height 29 inches_-_-_-_-_-_-_-_-

KING HAROLD. 3. Deep oxblood-red, with purple-black base; large flower of fine form, on a sturdy stem. Superb variety for the border, and most effective in partial shade. Height 24 inches...._._.

LA CANDEUR; syn., WHITE QUEEN. 2. Almost white when mature; with black anthers; medium size. Height 24 inches_._._._._.-.

LA TRISTESSE. . Dull slate violet with white base; large flower. Very distinct color. Handsome. Height 26 inches._._.

LA TULIPE NOIRE. 3. Dark maroon-black, the blackest of all the Tulips. Large flowers. Height 25 inches._.

LE NOTRE. 3. A grand new Tulip, excellent for forcing for exhibition purposes. Beautiful pink, with large, dull base, rayed blue and white. Height 26 inches

LOUISE DE LA VALLIERE. 3. Brilliant cherry-rose with blue base. A magnificent Tulip. Height 24 inches.-_.

MADAME KRELAGE. 2. Bright lilac-rose, margined pale silvery-rose; inside soft rose-pink; long flower. Height 28 inches.-_-

MARGARET; syn., GRETCHEN, 3. Silvery pale rose, flushed white. inside soft

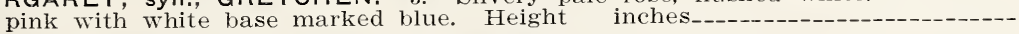

MASSACHUSETTS. 2. Vivid pink, edged rosy-white, white base. Large flower of beautiful color. Height 26 inches_-_-_-_-

MASSENET. 3. Opening deep rose with edge of paler rose, facing to pale rose; inside creamy-white, base bright blue. A flower of large size and one of the handsomest. Height 30 inches.

MELICETTE. 3. Soft lavender; inside dark lavender-violet with beautiful blue base. The purest lavender Darwin. Height 25 inches.--

MR. FARNCOMEE SANDERS. 2. Scarlet; inside vivid cerise-scarlet with white base; large. Flower of perfect shape. One of the best among the reds. Height 25 inches.

MRS POTTER PALMER; syn. Mr. D. T. Fish, Fashion. 2. Deep purple. A very fine Tulip for the border.-_-_-_-

MYSTERY. -2. Tery large and beautiful shiny black flower with circular blue base. A most effective variety. Height 23 inches._-_-

MRS. STANLEY. Violet-rose-1NAUTICAS. 3. Unusual tone of dark cherry-pink. Very beautiful grouped near
Malus floribunda and white Wisteria with foreground of Iberis sempervirens. Malus floribunda and white Wisteria with foreground of Iberis sempervirens. 
PAINTED LADY. 3. Creamy-white, tinged soft heliotrope. The best white Darwin. Height 27 inches__.

PHILIPPE DE COMINES. 1. Pulple-maroon; large flowers on stiff stem. Height

PRIDE OF HAARLEM. 1. Billiant rosy-carmine with blue base; very large flower on tall, strong stem; sweet scented. Unsurpassed for borders. Height25 inches

PRINCESS ELIZABETH. 2. Clear deep pink, changing with age to rose-pink,

white base. Large flower. Height 26 inches-
PROFESSOR RAUWENHOF. 3. Eright cherry-red with scarlet glow inside; bril-

liant blue base. Enormous flower on a strong stem. Height 28 inches.-------
PYSCHE. 1. Silvery rose, edged soft rose: inside shaded silvery-rose with pale blue

base. Large flower. Height 26 inches.

gIERAAD VAN FLORA. 2. Bright red, blue base; magnificent flower of a very dis-

tinct color. Height 24 inches blue base.

WILLIAM PITT. 2. Very dark crimson, with purplish bloom on the outer petals and white base starred blue; large flower of distinct color and great beauty. Fine for borders and for forcing. Height 22 inches.

WILLIAM COPLAND; syn., Sweet Lavender. 1. Lilac- rose; not a large flower but of merit because it may be forced as easily as the early Tulips. 25 inches.-..-

SUPERB MIXTURE OF DARWINS. This is out own special mixture which we recommend where the best results are desired in beds of mixed colors. It is made up of named sorts_.

\section{DARWIN TULIP COLLECTIONS.}

50 BULBS in 5 separate named varieties, our selection

100 BULBS in 10 separate named varieties, our selection

300 BULBS in 10 separate named varieties, our selection

1000 BULBS in 20 separate named varieties, our selection

The varieties from which these collections are made up are carefully selected from our general list.

\section{FAMIOUS OLD DUTCH BREEDER TULIPS.}

The Breeder Tulips have been famous in Holland for centuries, but it is only within recent years that they have become known and appreciated in America, and now they bid fair to rival the Darwin Tulips in popularity.

Their majestic size and remarkable colors place them distinctly in a class by themselves. Every lover of the more somber shaces cannot fail to revel in the rich and artistic blendings of purple and old gold, bronze and terra cotta, brown and violet, and buff and maroon found among the Breeders. They are late to bloom but surpass in size and vigor the Darwins, although lacking the color brilliancy of the latter. The flowers are, many of them, sweet scented, and all splendid for cutting, as they retain for a long time their form and color.

ALCIDA. 2. Light bronze, edged golden-yellow which, with age, becomes soft primrose-yellow; a meaium sized flower of clear tone, with fine green base. primrose-yellow; a meaium sized flower of clear tone, with fine green base. 35 inches.

BRONZE QUEEN. Large, strong flower; stout stem; fine form; purplish-fawn, interior buff-yellow, bright lemon-chrome base; filaments olive above, yellow below. Height 28 inches.

CARNATION. Pure white, rosy shade heliotrope outside; deep mahogany-hrown within, shading to golden-brown at tip of petals; yellow base. The general effect at a distance is a bright yellowishbrown. Height 24 inches.

KLOPSTOCK. A very handsome Tulip; bishop's purple, margined with purplishlilac, edged rosy-white, large, pale yellow base, with blue siar. 24 inches.-.--

MADRAS. Golden-bronze, with dull heliotrope stripe on the outer peta!s, yellow base starred green. A long, good sized flower. Height 26 inches___._.-...-.

VELVET KING. Immense flower on extra strong stem. Its robust growth makes it one of the showiest and most conspicuous; fine supshaped form; bright, dark, royal purple, small, white, sharply defined base. A giant. Magnificent planted in masses of yellow Pansies, or dotted through a large planting of the fine pale heliotrope Darwin Tulip, Dream. Height 31 inches...- 1.50 


\section{CHOICE MIXED BREEDER TULIPS.}

Mixed bulbs, as a rule, do not appeal to the planter of bulbs because it does not make possible the blending of colors. Breeder Tulips, however, are in a class by themselves and their colors do permit easy blending. They are in shades of bronze, goldenbronze, violet, buff, maroon and terra cotta. We suggest a liberal planting for cut flower's.

Per 10, 60c. Per hundred $\$ 5.00$.

\section{PARROT TULIPS.}

We urge you to grow some of these quaintly shaped flowers particularly for house decoration. The artistic forms and colorings make them especially suitable for cut flower purposes; in the garden, if planted in borders or groups, they are not always satisfactory, as they lack the vigorous, straight stems of the other Tulips.

No. 1-Mixed 10 for $55 \mathrm{c}-100$ for $\$ 5.50$

\section{REMBRANDT TULIPS.}

When the coloring matter of a "self color" has become split up into stripes and blotches, that particular flower is called "broken" or "rectified." "When the Darwin Tulips "break" into these variations, they are called "Rembrandt Tulips," they are very decorative but should be planted by themselves.

No. 1-Mixed 10 for $55 \mathrm{c}-100$ for $\$ 4.50$

\section{COTTAGE OR MAY-FLOWERING TULIPS.}

The Cottage Tulips come into bloom in early May, after the Early Single varieties have passed. They are hardy and robust, with long, slender, but very stiff stems. The flowers are mostly long and oval, many of them with the petals gracefully reflexed. The Cottage Tulips as a class are rich in the more delicate and artistic shades of yellow, orange and fawn, with salmon, old rose and amber. They are the best of all Tulips for cutting and they develop best when planted outdoors, including the earlier kinds.

$10 \quad 100$

INGLESCOMBE PINK. Salmon-pink, blue base; very brilliant_-_-_-_-_-_-_-_-_ $\$ .45 \$ 3.50$

LA CANDEUR; syn. PARISIAN WHITE. Silvery-white; as the flower ages it

turns to a soft rose; medium size and globular form. Fine for borders. $16-i n . \quad .60 \quad 5.00$

PARISIAN YELLOW. Golden-yellow; pointed_-_-_._- 55

PICOTEE or MAIDEN'S BLUSH. Long; clear white; the petals, which are pointed and elegantly reflexed, are beautifully margined and penciled on edges with

bright pink

PARISIAN SCARLET. Bright scarlet_____._.

THE FAWN. Pale rosy-fawn, changing to cream, flushed blush-rose; large, eggshaped flower of exquisite beauty on graceiul stem. A gern tmong late Tulips. Height 20 inches. A gem tmong rate 1 uns. 55

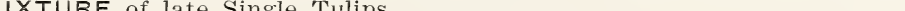

\section{LILY FLOWERING TUILIPS.}

As the result of crossing the dainty pointed-petaled Tulipa retroflexa with a pink Darwin, we have here a new, very beautiful, and distinct race of Tulips having graceful, slightly reflexing fiowers on tall, sturdy stems.

ADONIS. Long, fine shaped flower of a vivid rosy-red-_-_-_-_._- $\$ 1.25$

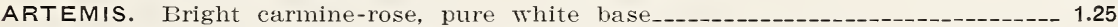

SIRENE. A very beautiful flower. Rich cerise-pink with pale pink at the margins

of segments, white base. Fine forcer. Great exhibition flower.

\section{SINGLE EARLY TULIPS.}

Including the best of the recent introductions.

They are the best fitted of all Tulips for forcing, if not grown too cool, some very early varieties may be had in flower by the end of December. When used for bedding, it is far better that new bulbs be secured each year, for the old bulbs will not do well 
the second season unless they have been allowed to mature and the foliage to die down before being removed from the beds. Even with the best care, it is uncertain whether the bulbs will again bloom successfully during a second season.

In the following list the handsomest sorts alone are represented, while many of the better known var:et:es are omitted because they are surpassed by the newer kinds. Detailed planting directions are included with the invoice.

ARTUS. Bright scarlet; a favorite-_-_-_-_-_-_-_-_-_-_- .55

$\$ 4.50$

COTTAGE MAID. (La Precieuse) Bright pink. Splendid bedder.-_-_-_-_-_-_-_-- $\quad .70 \quad 6.00$

CRAMOISI BRILLIANT. Brilliant scarlet. A splendid bedder and sure forcer. Very

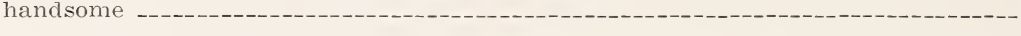

KEIZERSKROON. Large, scarlet flower, edged with bright yellow. A good forcer.

Height 16 inches.-.._-_. 85

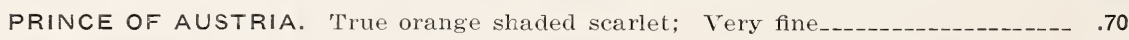

WOUVERMAN. (2). Rich purple-violet; large flower. Beautiful when planted be-

side a white variety. Height 12 inches. -

4.50

$50 \quad 4.50$

7.50

6.00

SUPERB SINGLE MIXED. This is our own special mixture which we recommend

where the best results are desired in beds of mixed colors. This mixture is

made up of hundreds of named sorts._.

\section{DOUBLE EARLY TULIPS.}

The double varieties cannot be forced so early or readily as the singles. The flowers are large and brilliant and are effective in beds or groups. If grown in pots, do not attempt flowering before they are well rooted.

RUBRA MAXIMA. Glowing scarlet; large and very double

MURILLO. Delicate blush pink. A very fine flower with a lovely color. An old variety but still one of the handsomest of the double Tulips. It forces very

easily - Bright scarlet; splendid bedier; large, weil shaped flowers on strong stems

TITIAN. Bright scarlet; splendid bedaer; large, weil shaped flowers on strong stems
DOUBLE MIXED. This is our own special mixture which we recommend where

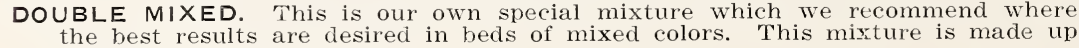
of the best nained sorts_...

$\begin{array}{ll}.55 & 4.50 \\ .65 & 3.50\end{array}$

$.55 \quad 4.50$

\section{HOME GROWN TULIP BULBS.}

If you desire some planting stock Tulip Buibs, we can offer you at $70 \mathrm{c}$ per pound:
EARLY SINGLE MIXED.
DOUBLE MIXED.
DARWIN MIXED.

COTTAGE MIXED. BREEDERS MIXED.

Also many named varieties of Darwins.

Most of these will bloom the first year after planting.

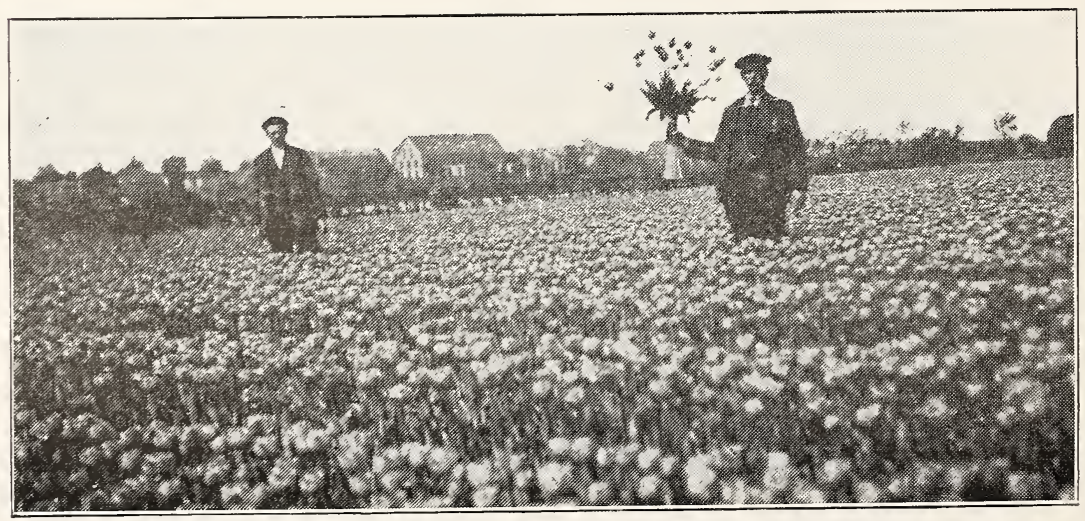




\section{SELECT EXHIBITION HYACINTHS.}

Bulbs Measure 19 Centimetcrs or Over and are the Largest Obtainable.

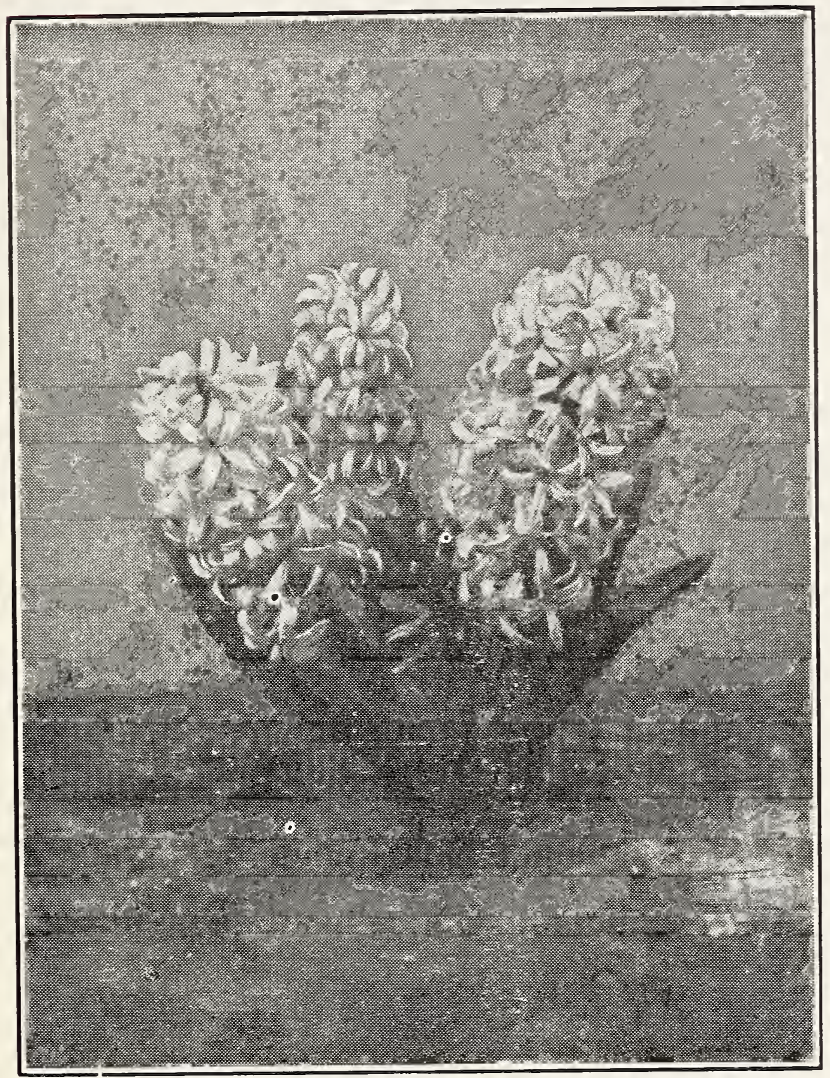

These are varieties selected for their large sized spikes, elegance of form and beauty and richness of color. The bulbs are of mammoth size-the cream of the crop-and naturally advanced prices. We offer this grade only in limited quantities and recicest early orders for them. Exhibition $\mathrm{Hy}$ acinth bulbs are unsurpassed for growing in pots but are not suitable for outdoor work; they are to grow in Hyaçinth glasses; may be flowered in any large vase, if this is preferred to pot culture.

All bulbs as listed below:

\section{$25 \mathrm{c}$ each $\$ 2.00$ for 10}

LORD BALFOUR. Lilac shaded violet; enormous trusses.

ROI DE BELGES. Brilliant crimson-sca:let.

GRAND MAITRE. Deep blue with long, compact spikes of large bells, on strong stems. One of the most popular blues; fine for pots as well as bedding.

KING OF THE BLUES. Dark violet-blue; splendid large trusses. One of the best knomn varieties of blue Hyacinths. Good for late forcing and bedding.

MENELIK. Very dark, almost purple; well formed trusses. A splendid bedder and good forcing. CITY OF HAARLEM. The finest of the yellows. Well formed trusses of orange-yellow bells. An excellent variety for forcing and bedding.

BISMARK-Light blue shaded violet. KING OF THE BLUES-Dark Blue. LADY DERBY-Bright rose-pink. L'INNOCENCE-Pure white.

ROI DE BELGES-Brilliant crimson-scarlet.
CARDINAL WISEMAN-Brilliant red. GERTRUDE-Deep rose-pink.

LORD BALFOUR-Lilac shaded violet. VICTOR EMANUEL.

LA VICTOIRE-Very dark pink. 


\section{THE SAM CARPENTER GARDENS}

\section{NAMED SINGLE BEDDING HYACINTHS.}

\section{4-15 Centimeters.}

We strongly recommend the use of Named Bedding Hyacinths for outdoor planting in preference to unnamed Hyacinths under color. The latter are made up of many varieties in mixture, which are not uniform in height, color, or time of blooming. When named bedding Hyacinths are planted, uniform ty in color, height of plant, and time of blooming are insured and at a cost not much in excess of unnamed bedding Hyacinths.

First size or exhibition size bulbs are tco costly for bedding and flowers are too heavy, falling over from their own weight.

$17 \mathrm{c}$ each.— $\$ 1.45$ for $10 .-\$ 12.50$ per hundred.-1C0 may be ordered assorted.

L'INNOCENCE-TWhite.

QUEEN OF THE WHITES Waxy-white.

LADY DERBY-Bright rose pink.

QUEEN OF THE PINKSLively pink.

GRAND MAITRE-Deep porcelain-blue.

QUEEN OF THE BLUESDeep azure.

YELLOW HAMMER-Bright yellow.

GIGANTEA-Very large, dainty bluish-pink.

MARENO-Pink..

CARDINAL MANNINGBright red.

CARDINAL WISEMANBrilliant red.

GERTRUDE-Deep rosepink.

GEN DE WET-Light blue. ELECTRA-Light silveryblue.

GRAND LILAS-Deep blue.

DR. LIEBER-Lavender blue shaded violet.

SIR WM. MANSFIELDRuby-violet.

LORD BALFOUR-Lilacshaded violet.

LA GRANDESSE-Pure white.

LA VICTOIRE-Very dark pink.

BISMARK-Light blue, shaded violet.

KING OF THE BLUESDark blue.

PERLE BRILLIANT-Light blue, tinged lavender.

CITY OF HAARLEM-finest yellow.

MARCONI-Bright red shaded white.

ROI DE BELGES-Brilliant crimson-scarlet.

GARIBALDI--Crimson.

PINK PERFECTION-Light carmine rose.

HALFGARNER KUHERT-Bright rose-pink..

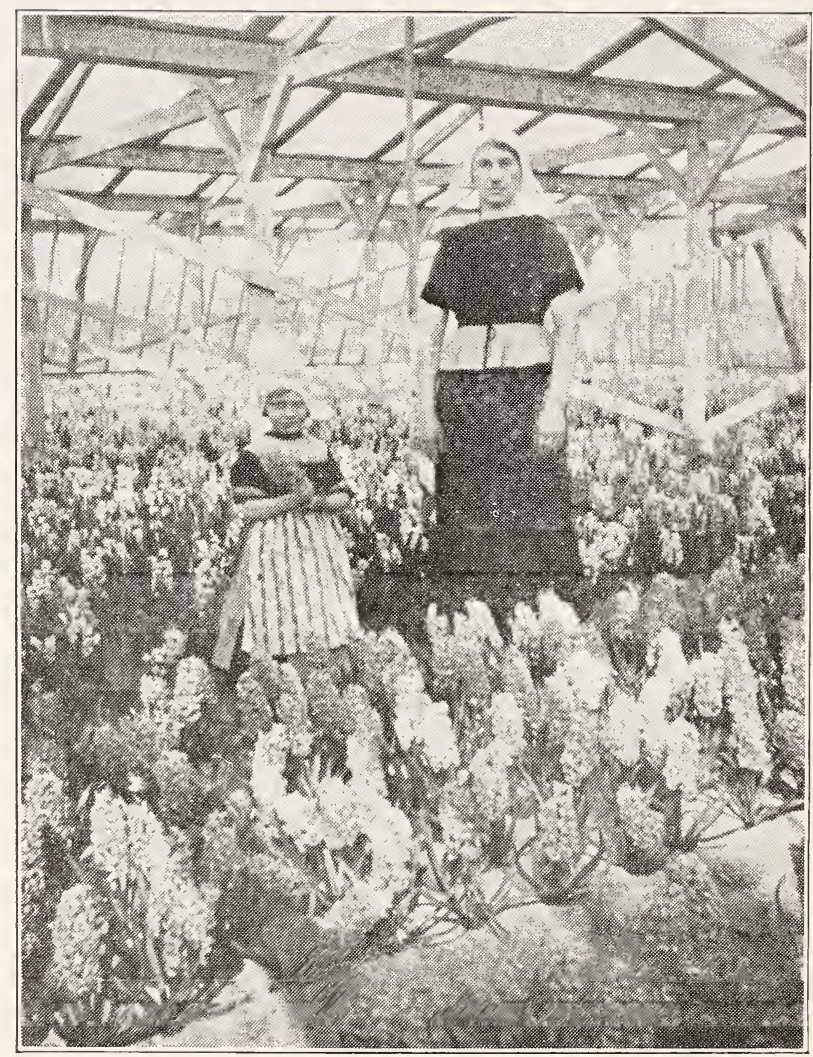

SCHOTEL-Clear porcelain-blue.

HEIN ROOZEN-Extra large white.

MENELIK-Very dark, almost purple.

GRAND BLANCHE-Blush white.

KING OF THE YELLOWS-Large yellow. 


\section{Narcissi - Daffodils}

(American Grown.)

Daffodils are not particular as to soil and will thrive for a number of years in ordinary soil. They are, with few exceptions, suitable for naturalizing, and, while preferring partial shade, will thrive in full sun exposure. They are very c'esirable for pot culture, three to five bulbs in a 5 or 6 inch pot producing an attractive group. By planting varieties in succession, a gorgeous display may be enioyed throughout the first three months of the year.

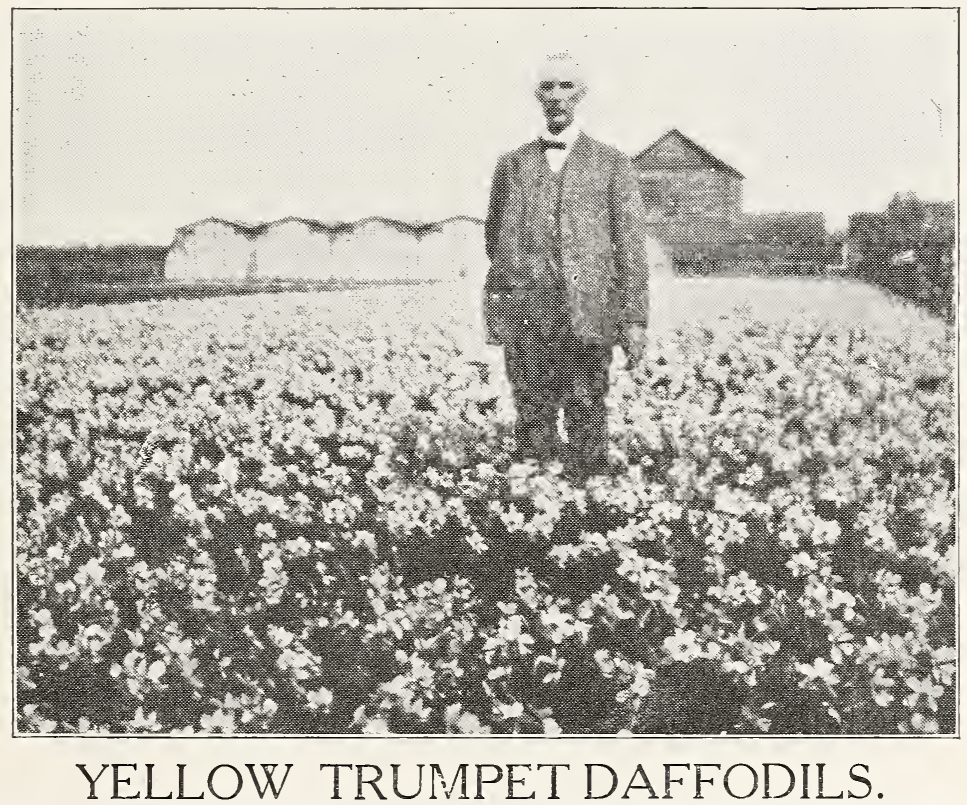

Varieties with yellow or primrose trumpets and petals of the same colors.

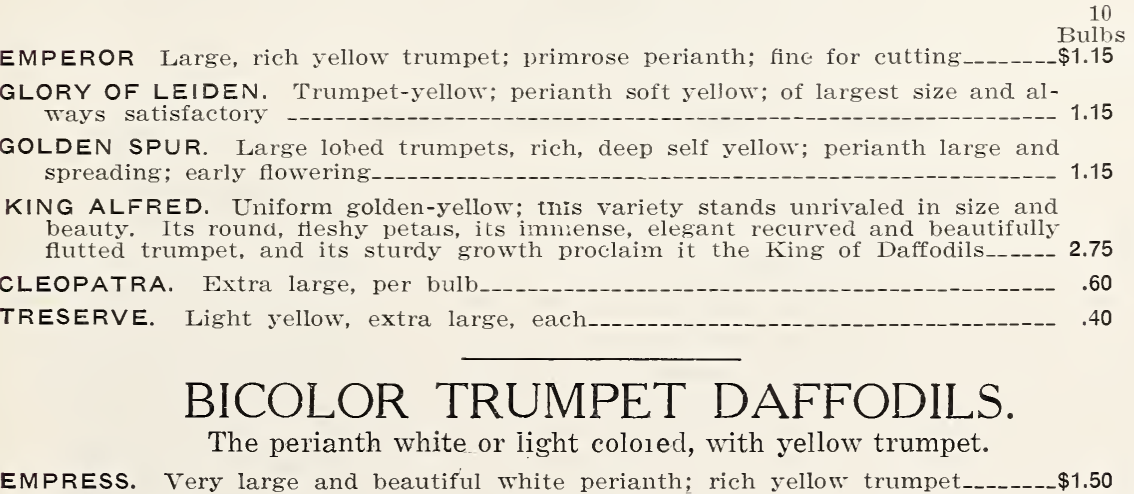
$\$ 1.50 \$ 12.00$

GIANT PRINCEPS. Sulphur perianth and yellow trumpet;long and showy_-_-_-_ 1.20 10.00

VICTORIA. Large, erect flowers; creamy-white perianth and rich yellow trumpet;

forces easily - 


\title{
THE SAM CARPENTER GARDENS
}

\section{WHITE TRUMPET DAFFODILS.}

WHITE LADY. Broad white perianth; dainty cup shaped, soft lemon. Beautifully crinkled. A very pretty flower-

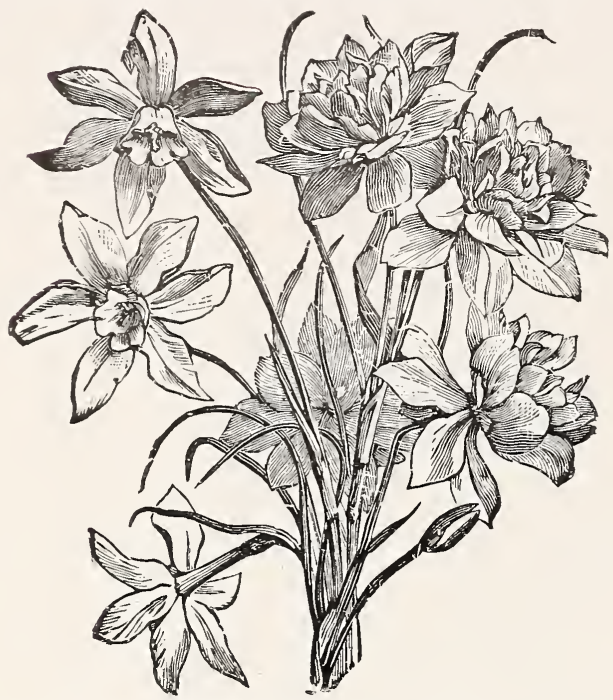

\section{Narcissus Incomparabilis}

These are known as the Chalice-Cup Daffodils, and, like all the short-trumpet varieties, they possess a certain elegance and airy grace which is not to be found in the giant-trumpet class. All of them naturalize readily.

LUCIFER. Large, sulphur-white, loosely formed perianth; cup chrome-yellow, edged

bright orange-red _._-_._. $\$ 1.50$

SIR WATKIN. (Giant Welsh Chalice flower.) Largest of the Incomparabilis var-

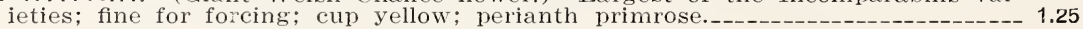

10.00

\section{NARCISSUS BARRI.}

Star Narcissus Class. Very useful for pots, cutting or borders. This class is one of the best for naturalizing in front of shrubbery and will increase from year to year, making in time a very effective colony.

CONSPICUOUS. Large, spreading yellow perianth; fine scarlet cup; strong grower;

fine blooming and durable cut flower variety

\section{Some Bargains in Narcissus.} Bulbs for Naturalizing.

\author{
Single planting size.
}

POETICUS RECURVUS (Pheasant's Eye.) 2.5 for $\$ 1.00 . \$ 3.00$ per hundred; $\$ 25.00$ per 1000.

BARRI CONSPICUOUS-20 for $\$ 1.00 ; \$ 4.00$ per $100 ; \$ 30.00$ per 1000.

SIR WATKIN-20 for $\$ 1.00 ; \$ 4.00$ per $100 ; \$ 30.00$ per 1000 .

EARLY YELLOW TRIUMPH-25 for $\$ 1.00$; $\$ 3.00$ per 100 ;

$\$ 25.00$ per 1000 .

GOLDEN SPUR-10 for $\$ 1.00 ; \$ 8.00$ per 100 .

KING ALFRED-5 for $\$ 1.00 ; \$ 15.00$ per 100 .

VAN WAVERIN'S GIANT-4 for $\$ 1.00 ; \$ 20.00$ per 100.

OLYMPIA-4 for $\$ 1.00 ; \$ 20.00$ per 100.

\section{CROCUSES.}

DUTCH VARIETIES-Mixed, 10 for $40 \mathrm{c} ; 100$ for $\$ 3.00$.

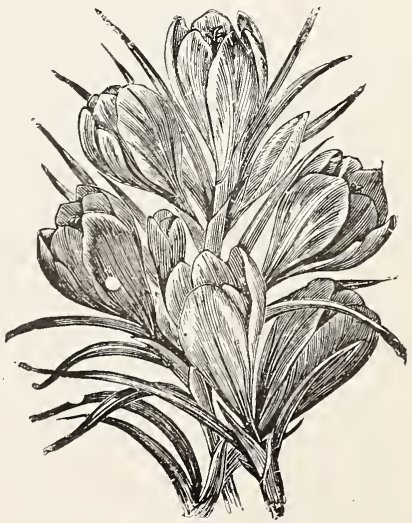




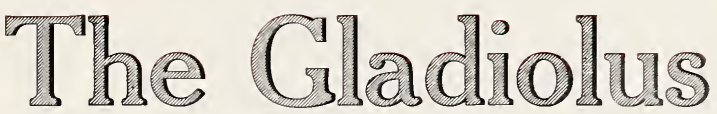

\section{IS GROWING IN POPULARITY EACH YEAR AND WITH AMAZING RAPIDITY.}

From obscurity a few years ago, it is now universally grown and admired by millions.

Societies have been formed, magazines are printed and immense sums are spent annually in advertising this most beautiful of summer flowers.

Flower lovers everywhere are becoming more enamored of and filling their gardens with beautiful Gladiolus, and are eagerly buying the newer and finer ones as introduced.

Many men and women of wealth are assembling large collections and the Gladiolus are the chief garden attraction.

They are easy to grow and adaptable to all gardens. Nothing else provides so much beauty over a long blooming season in any soil and every climate for so small an amount of money.

They are free from diseases and insect encmies, and are the most satisfactory flower to grow as no other flower yields such results for the labor expended.

The bulbs increase rapidly and can be planted year after year and the surplus given or sold to enrich a neighbor's of friend's garden.

You will find the few hours' time devoted to growing and cultivating them abundantly repaid and as you keep growing them your enthusiasm is bound to increase.

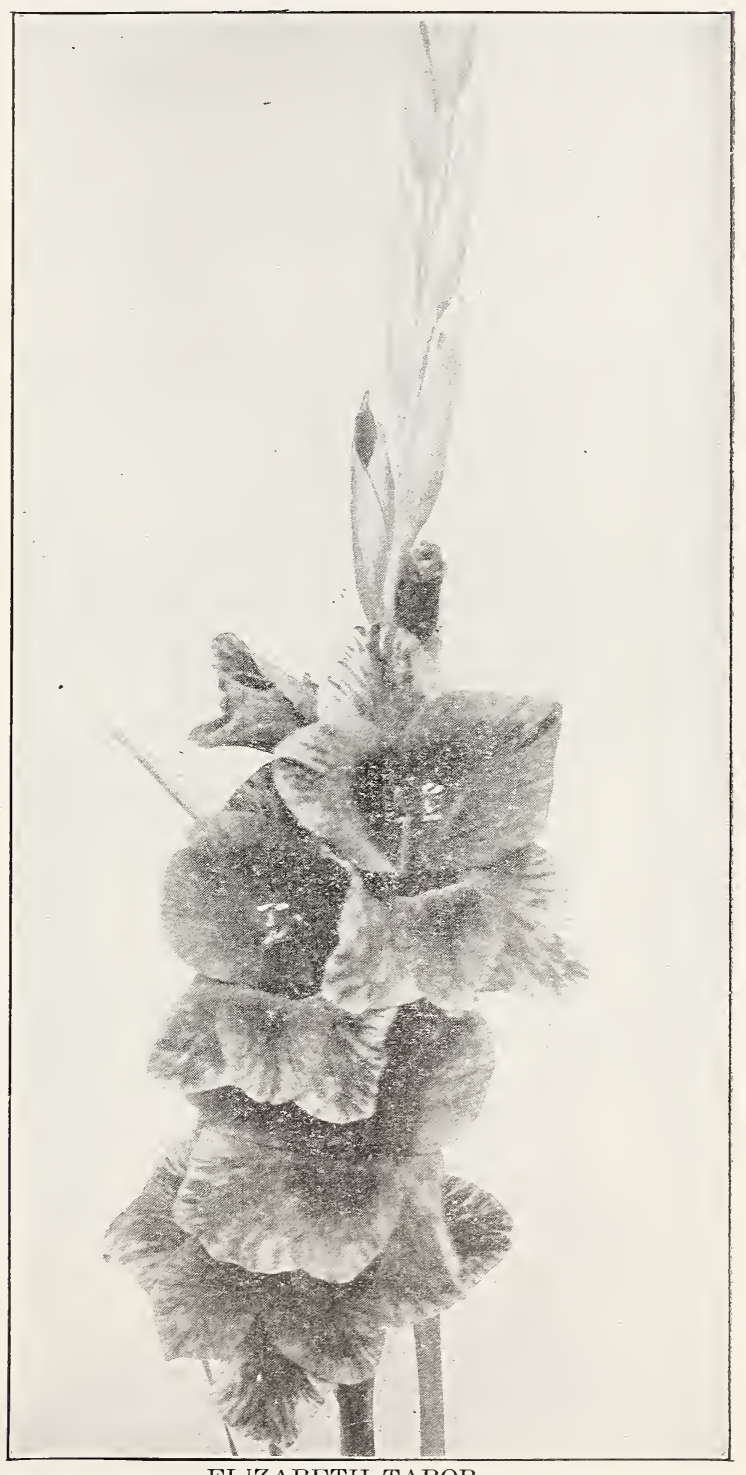

ELIZABETH TABOR.

If you follow the instructions given here your success is certain.

Select good bulbs of best varieties, and this does not mean the highest priced ones, for many of the best are inexpensive because more plentiful. 


\section{THE SAM CARPENTER GARDENS}

We have reduced our list to 74 varieties, omitting all buc approved moderate priced varieties, and yau can make your selection from this list with the assurance of getting real glad satisfaction.

There is not a poor Glad in this list, and it contains the best of. the good ones.

Success is assured in growing Gladiolus if you have good soil, give frequent cultivation and plenty of water.

They grow equally well in nearly all sections of the country, b th north and south, and can be truly called the universal flower.

Any good garden will grow them, but if of a heavy composition it can be mellowed by adding sand, leaf mould or sifted coal ashes.

Gladiolus do best in a sunny location, away from roots of trees and shrubs, but they do will in partial shade in borders or beds with other flowers.

If you change the place of planting each year they do better. The richer the soil the finer the bloom, and a good covering of manure on the beds in the fall preceding the planting is beneficial.

Planting should begin early in the spring and successive planting each week or two until June, will produce a long continued season of bloom. The larger bulbs bloom first, and the smaller bulbs may not produce as

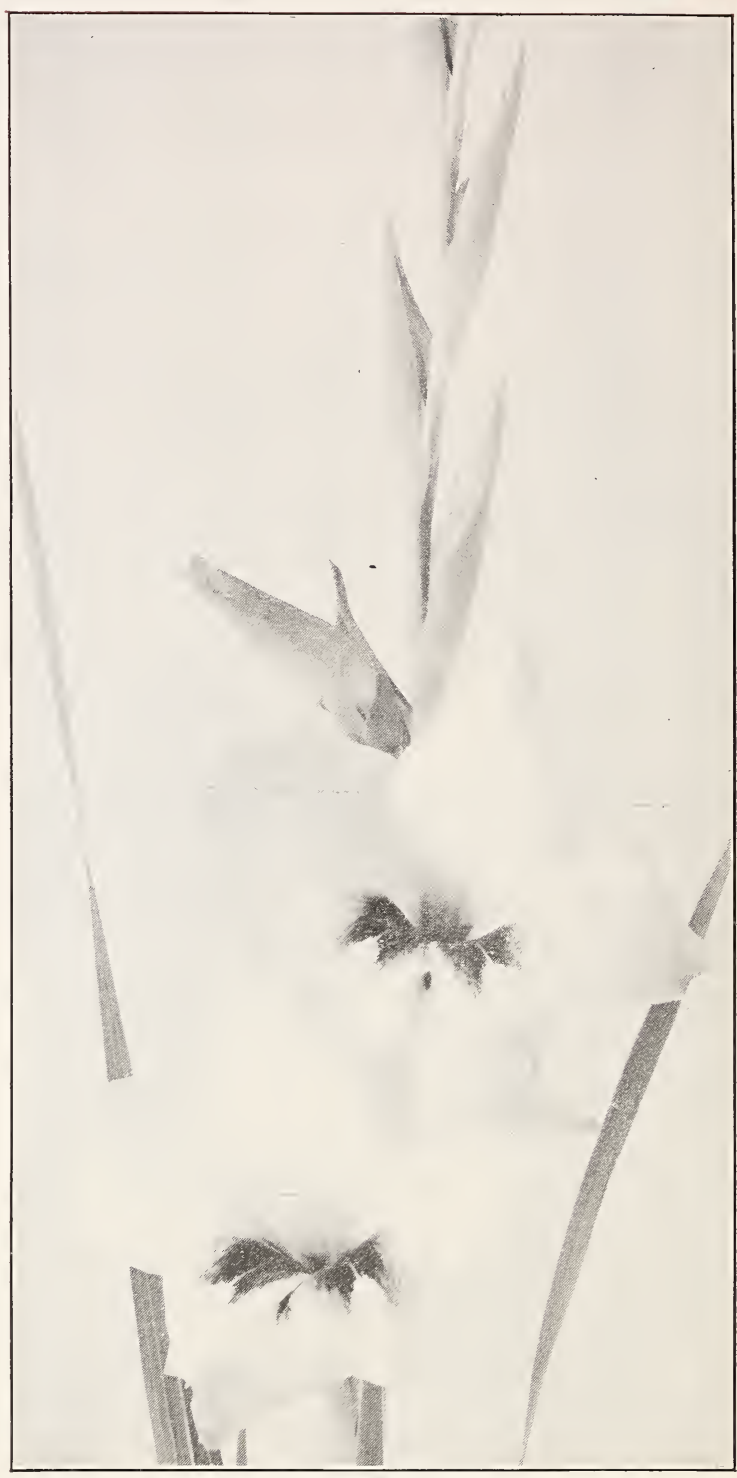

ANNA EBERIUS. large spikes, but the blooms are generally as large the first year and they increase each year. Bulbs should be planted four to six inches deep and four to eight inches apart in the row. Good and frequent cultivation is essential and spells success.

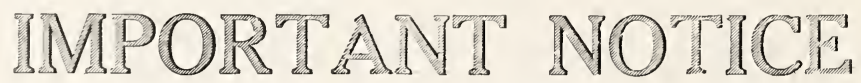

Why follow old customs when new ones are better? This catalog is DIFFERENT. We call your attention to the fact that the names of the different varieties are properly indexed, and indexed as you have learned to read an index. 
If you want to find a name of any variety, just turn to it as you would if looking for it in the telephone book. If you wish to find "Mrs. F. C. Peters," do not look under "M" but look under "P" where it kelongs and you will find it thus: PETERS, MRS. F. C.

\section{ONE DOZEN BULBS OF ANY ONE VARIETY AT PRICE OF TEN.}

Two years ago we catalogued 250 varieties, the best from every prominent grower in the country, probably one-third of these costing us and listed at $\$ 1.00$ to $\$ 5.00$ per bulb. Shortage of help and pressure of other work prevented our keeping these varieties separate in digging, and they were all mixed together forming probably the finest mixture offered by any grower, as many of our customers have testified this past season.

This mixture is made from the best named varieties in commerce, including rare and expensive novelties, and you can make no mistake in buying it.

The President of the Kansas State Florists Association said that some blooms we sent to Coffeyville last season, grown from this mixture, were the finest he had seen.

We are selling this superfine mixture at 5 cents per bulb, 50 cents per dozen or $\$ 4.00$ per hundred.

ALBANIA (Kemp) First Prize, Boston, 1921; New York, 1921-22. This is the most pleasing white variety we have ever seen. The color is of the purest glistening white, the flower wide open, four inches and over in diameter; petals are broad, with wellrounded tips, and the finely ruffled edges of the petals give the individual flower an artistic finish such as is seldom seen in the Gladiolus. The flowers are correctly placed on the spike, and set just close enough together to close up the intervening spaces, making an ideal and the best white for floral designs ever originated. Five flowers open at a time and a splendid keeper when cut. Height four feet, 15 to 17 flowers to the spike, very healthy, vigorous grower, and a very bountiful producer of good sound bulblets that grow. Many commercial growers in the United States and Canada have proclaimed "Albania" the best commercial white variety in existence.

AMERICAN BEAUTY (Diener) Brilliant American Beauty color. Throat creamy-yellow striped with ruby. One spike opening a large number of flowers at one time forms an immense bouquet. Flowers very large.

\section{ASHE, EMILE (Diener)}

Snow white petals. Small cerise blotches on lower petals. Edges heavily ruffled. This is one of the best ruffled varieties ever offered.

BENNETT, DR. F. E. (Diener) Peach-red, overlaid with flame-scarlet, throat specked with ruby and white. A very attractive large red, with plenty of vigor. The flowers have good substance and the arrangement is good. making it one of the most popular of the new introductions.

BUTTERBOY (Prim) (Kunderd) -

A large pure buttercup yellow Primulinus, distinctly different from other yellow prims. Tall, slender. graceful, bright. Vigorous habit. Early (XXXX). BOTHIN, MRS. H. E. (Ruffled) (Diener)--
Light geranium pink, heavily ruffled. Flame scarlet center. Strong, well built spikes; first class show and cut flower variety. One of the loveliest combinations in Gladiolus. It has created a sensation wherever produced. A heavy propagator.

CARBONE, J. A. (Diener) Orange salmon, very iridescent, darker shading toward the outer edge of the petals. Yellow center. Fine, long, well built spikes. One of the largest and finest productions.

COLEN]AN, JOE (Coleman)

A very bright spectrum-red with a carmine blotch; an extremely attractive color with many flowers open at a time. A strong grower and good propagator. Very popular.

CRIMSON GLOW (Betscher) Scarlet-red, slight stippling of primroseyellow in throat overlaid with a velvetyscarlet blotch. One of the best of its color.

DICK

The best selling blue in our field. It is medium size, but its beauty appeals to all. A blue with the two lower petals a deep nansy blue with a gold stripe running through the center.

DIENER, RICHARD (Ruffled) (Diener)--Pale geranium-pink, occasional flaking of rose-doree; throat blotched bariumyellow, lightly stippled carmine: midribs sometimes barium-yellow. This is a well ruffled variety and comes well arranged on the stem with many open at a time. One of the very best.

\section{DOUGLAS, MRS. LEON (Diener)}

Ground color hegonia rose striped with flame and hrilliant scarlet. Lip pale lemon slightly speckled with ruby. The size of the flowers, we believe, are the largest in existence, and a!l a"r $o^{-} e^{-}$n nd well set on long spikes. Sniln are exira long and have up to as nany as seven side spikes on each main one. Bulbs are of very large size.

EBERIUS, ANNA (Diener)-- shading into
Deep Rhodamine-purple, sula Deep Rhodamine-purple, shading into
very deep bordeaux center. This variety has created a sensation everywhere with growers and amateurs alike. 
EDISON, THOMAS

Dull salmon-color. Wonderfu! spike. large blooms. Tery clear. First class Certificate.

ELF (Diener)

Lemon yellow when in bud. Open flower's pure white. Lip delicate lemon. Large flowers on a perfectly built spike. Even the sniallest bulblet will produce a large flower spike. A commercial varriety of great promise.

ELORA (Burbank)

White, slightly flushed pink; throat sulphur-yellow with a carmine blotch. A Burbank production of much promise; ver'y early.

FLORA (Velthuys)

Naphthalene yellow, throat suffused barium yellow, with just a trace of red deep in the throat and at base of petals. The cheapest yellow.

FOCH, LEMARECHAL (Van Dursen) Glistening white, suffused cameo-pink; reverse suffused rosolane-purple. Very large florets, well arranged on the stem. This is one of the best of the Holland introductions. Very prolific. A remarkable Glad at the price. Early (XXXX.)

FOCH, MARSHAL (Kundred)

LaFrance-pink, overlaid Geranium-pink; blotched scarlet-red in throat. Very large, wide-open flowers, growing on good sturdy stems. A Grand Gladiolus named after a great man. Should be in every collection.

FORD, HENRY (Diener) $A$ very dark rhodamine-purple. Color very similar toAnna Eberius, but it is clearer and not flaked so much. This is the variety that was listed at $\$ 200.00$ each, two years ago.

GIANT NYMPH (Coleman)

LaFrance-pink; with creamy-yellow throat; very large wide-open flowers, long spikes and flower's well arranged on the stem. This is without question one of the very best recent introductions. If it is not in your collection, buy it.

GIANT SALMON

Just as the name implies. Large well placed salmon colored flowers, many open at one time. Vigorous grower and a. favorite.

GLADDIE BOY (Bill)

It is of the semi-primulinus type retaining the delicate characteristic coloring but in a form more massive. Flowers are well expanded with only slight hooding effect. Spikes have 18 to 20 buds and opening 6 to 8 perfect flowers at a time. The color is distinctive, the general effect being a Grenadine pink gradually blending with straw-yellow deep in the center. To further enhance its beauty, the petals are most gracefully frilled.

\section{GOLD (Hoeg)}

Naphthalent-vellow, shading to bariumyellow; a fine clear self-color. Said to be the best yellow yet produced. The color is fine, the arrangement good, and as a cut-flower variety for florists' use, it ranks well.

GOLDEN MEASURE (Kelway)

Straw-yellow, lower petals suffused amber-yellow. A very strong, vigorous grower and in our estimation the best pure yellow on the market.
JEWEL (Prim.) (Zee)-_golden-yellow throat. A large wide-open flower that does not show the hooded form of the Primulinus.

KENT, THOS. T. (Diener)

Pale hermosa-pink, suffused Begoniarose, flaked spectrum-red. Throat Marguerite-yellow, blotched carmine. Very striking. A large tall-growing variety with plenty of flowers open at a time. This variety is sure to attract attention and much favorable comment.

KENT, WILLIAM (Ruffled) (Diener) Ivory-yellow, suffused a rose-pink at edges; throat buff-yellow primrose, sprinkled carmine. Well ruffled, with 8 to 10 blooms open at a time and good arrangement on the stem. We consider this the best of the Diener originations, having exceptionally good form and the color harmony is very pleasing.

KING, MRS. FRANCIS (Coblentz) Jasper red, lower petals splashed deeper red, throat lighter. Tall straight spikes. Very large flowers of fine substance and arrangement. Excellent for forcing or cutting.

KIRTLAND, EVELYN (Austin)

LaFrance-pink, overlaid rose doree; throat blotched soft scarlet-red. Very pleasing color, arrangement good, strong upright grower. One of the very best for all purposes.

KUNDERD, MARIE (Kunderd) A pure glistening white, of particularly graceful form. Well ruffled and very delicate. This is undoubtedly the best of the early whites. Early.

LIND, JENNY (Ruffled) (Hoeg) Shrimp-pink deepening to Geraniumpink at tips of petals. Uniform coloring except mid-rib is lighter on all petals and a bloteh of baryta-yellow on the reverse side of lower petal. Flower's tubular. Spike compact. Flowers ruffled and edges rolled back. A very delicate variety, one of the very best for floral work. Should be in every high class collection.

LOS ANGELES (Houdyshel)

Shrimp-pink with orange carmine throat. The color tone is one of unusual delicacy and so pleasing as to be greatly admired. It is a favorite cut flower among the Hollywood motion picture stars. A wonderful fiorist's flower of individuality and distinction. We call this the everblooming or "cut and come again" glad on account of the exceeding abundance of blossoms produced. If planted very close each buib will throw from two to four spikes of exceptional length just right for florist's use. If planted far apart a great many branches are formed which may he removed as they bloom out. You will be surprised by the number of spikes produced on a single stem. If the entire stem is cut leaving sufficient foliage a fair proportion will throw a new branch just below the cut with a single spike oi rather darker flowers. These second growth stems are shorter but still are useful in floral work. The long blooming period and the great quantity produced give the "Los Angeles" exceptional merit for landscape work.

\section{5}


Light salmon with vermilion stripes. Canary-yellow throat with ruby stripes. It is perfect in every way. As a cut flower it is our most profitable variety.

LOUISE (Wright)

Glistening white suffused Phlox-pink. Phlox-purple at edges; throat blotched, true purple with nid-rib of rhodaminepurple; a very beautiful color and a strong grower.

MARK, MR. (Telthuys) Lobelia-violet suflused Saccardo's violet; throat barium-yellow with a blotch of amaranth-purple. This is one of the best of those commonly known as light blue varieties. Very popular as a cutflower variety.

MING TOY Prim.) (Kunderd) Pinard-yellow, suffused and etched bittersweet orange. This is one of the most popular of the Primulinus Grandiflora type. Color is distinctly different from all other Glads. A beauty.

MISS SPOKANE (K)

Dark salmon with darker throat. Strong grower and propagator. Very fine and showy. Good either in the garden or as a cut flower.

MONA LISA (Ruffled) (Kunderd) A very beautiful sliade of rose-pink, sometimes called bluish-white. A very pale shade almost a self-color. The most delicately colored Gladiolus that we know of. Well ruffled and exceedingly beautiful.

MURIEL (Pfitzer)

One of the most beautiful varieties on the market. True lilac slightly darker at tips of petals. Petunia violet blotch on lower petals. Strong straight spikes. Flowers large, excellent substance and arrangement, 14 to 16 on spike. Magnificent.

MYRA (Prim) (Kunderd)

A giant-flowered irnmumnus hybrid. Deep salmon-pink over yellow ground. Yellow throat with pink lines. Tall slender stems. Exquisite and showy.

NEGRI, POLA (Kunderd)

Apricot with yellow lip. Ruffled shading into old rose and salmon on the outer edges. One of the loveliest color combinations ever seen. Flowers on the spike sometimes come irregular. A very heavy propagator. We especially recommend this variety.

NORTON, MRS. DR. (Kunderd)

Hermosa-pink shading to Cameo-pink; very delicately flaked eosene-pink; throat barium-yellow, stippled with tyrian-rose. Large wide-open flowers that grow on tall slender stems; very graceful. One of the most beautiful of all moderately priced Gladiolus.

PENDLETON, MRS. FRANK (Kundred) -Deep rose-pink, shading to a pale pink throat, noted for large bright rose-red blotch on lower petals. Strong straight spike. In great demand.

PETERS, MRS. F. C. (Fischer)--A beautiful shade of amaranth-pink Sometimes referred to as an Orchid color. A very beautiful Gladiolus and very popular
PHIPPS, W. H. (Diener) LaFrance-pink overlaid with light rose salmon, lighter toward the center. Lowled with ruby. Flowers enormous. A masterpiece in Gladiolus.

PINK LILY (Kunderd)

Deep rose-pink. suffused rose color, on edges; throat blotched rose-red. A magnificent ruffled rose-pink. Fine spikes. Mid-season.

PIRIE, JOHN T. (K)

Mahogany brown; reddish-brown blotches on cream throat. Odd and distinctive. Very tall. Attracts everyone's attention. Should be in every collection.

PRIDE OF LANCASTER (Ruffled) (K) --Shrimp-pink, suffused peach-red; throat blotched scarlet-red. A very fine color. Very compact spike with bloom well set. This variety is sometimes described as a brilliant orange-salmon. Very beautifully ruffled and fine in every way.

PRINCE OF WALES (Van Zanten) Strawberry-pink shading to a very pale pink throat Faint scarlet blotch on lower petals. Strong spikes. Flowers large and well arranged. In a class by itself. Very early.

PURPLE GLORY (Kunderd)--_-_Tyrian-rose, suffused amaranth-purple;
slightlv flaked; a very dark, velvetypurple in throat. This is probably the most popular of all the "Glory" group. An excellent show variety. You can't have the best exhibition collection or the finest garden varieties without this wonderful Purple Ruffled Glory. It stands high in the list of best varieties.

ROMANCE (Kunderd) An unusual flower hard to describe. Orange, salmon-rose, red and yellow throat and with a bluish border surrounding each petal.

ROSE GLORY (Kunderd)

Eosine-pink, shading to hermosa-pink in throat: lower petals marked amaranth-purple. A beautiful ruffled variety which is very popular. Early midseason.

ROSE ASH (Diener) Corinthian red shading into ashes of roses on the outer edges. Lower petals light yellow speckled with ruby. Flowers large and well placed.

SALMON BUFF (K)

The name describes the color. Plant this one late and have fine flowers when your neighbor's are gone. Late.

SCHWABEN

Strong grower with heavy spikes of yellow flowers. The most popular standard yellow.

SCARLET PRINCEPS (Kundred) A beautiful red Gladiolus with six or more massive princeps like blooms open at a time, throat a little deeper. Placement almost perfect. An extraordinary, distinct and massive spike. Won a First Prize at A.G.S. Show, Rochester, 1925.

SCARLET WONDER (Cowee)

Iammoth pure deep scarlet flowers on tall strong stems. WVe all know Red Em. peror. Planted side by side with Scarlet Wonder, Red Emperor is a dwarf in height and size of bloom. 
SHAYLOR, E. J. (Kunderd) Deep, rose-pink to rose color; outer edges and buds a distint rose color. Throat of lower petals delicately penciled rosered. This is undoubtedly one of the most popular in the cut-flower markets, is a good propagator, vigorous grower, fine form and the color is very pleasing.

SMITH, BYRON L. (Kunderd)

White, delicately suffused light mallowpurple, deeper at outer edges; throat Irarguerite-yellow with etchings of mallow-purple at base. Exquisite. Sometimes referred to as the Orchid-colored Gladiolus.

SOUVENIR (Gravereau)

Pure solden-yellow Primulinus Grandiflora. First Class Certificate, Haarlem, 1921. The most perfect flowering Gladiolus of the purest golden-yellow color. it grows and multiplies rapidly. No collection should be good without this fine yellow.

SWEET LAVENDER (Coleman)

Light lavender, deeper in throat with purple blotch. The earliest bloomer in my garden.

SYMMES, FRANK J. (Ruffled) (Diener)--Geranium-pink, outer edges suffused rose-doree, blotched scarlet-red in throat. A strong sturdy grower and a splendid cut-flower variety, coming midseason to late Try it: it is one of the very finest ruffled varieties, and should be in every collection.

TABOR, ELIZABETH (Hinkle)

A high class introduction of exceptional beauty, grace and distinction. A sensational novelty, for it blooms earlier than any other!' The fact that it will bloom in forty-five to fifty days from planting will make it the leading first early. It has been universally referred to as the sensation of the Rochester show where it was given the Award of Merit of the America!n Gladiolus Society and won the Vaughan Medal for the best new market variety. Flowers are very large, and even under ordinary cultivation often reach six inches in width, an astonishing size! Petals are delicate rosy pink on white ground, lower ones bearing a rich dark crimson ilotch which terminates in a diamond of soft yellow. Grows tall, but rarely has a crooked stalk. Flowers spike very long, with a number of flowers open at once, gracefully placed.

TIPLADY, Alice (Prim.) (Kunderd) Bittersweet-pink, suffused scarlet at outer edges and reverse, throat buffyellow, etched scarlet. Commonly called. Orange-saffron. Strong grower, one of the best for landscape growing and for cut flowers.

TWILIGHT (Kundred)

An exquisite new production, as beautifut as a seashell. Creamy-white, flushed pink, with throat of blended pink and yellow. One of the most beautiful Kunderdi.

VAN FLEET, DR. W. (Kunderd) Delicate rose-pink, deepening at the edges of the petals. Throat of softest canary-yellow, beautifully blended. Extra tall and slender spikes. Early.

WHITE PIGEON (Kunderd) $A$ wonderful early, pure, all white. Very lorge blooms. A strong, healthy grower and rapid propagator.

\section{WHITE WONDER (Kemp)}

Almost pure white; faintly flaked rosepink. A very large flower well set on the spike and many open at a time. Very popular.

WILBRINK (Hopman)

One of the earliest. Pale livid pink, upper petals have a light amaranth-purple blotch on a yellowish ground. Strong spike. Many flowers open. Substance and arrangement fine. The excellent qualities of this variety both for forcing and cutting has made it the most popular variety on the market.

ZANG, GRETCHEN (Austin)

White, suffused LaFrance-pink, shading to geranium-pink on tips of petals; lower petals blotched rose-doree and scarlet-red. A strong grower and very popular as a cut flower variety.

ZANG, TYCKO (Austin) Tycko blooms are of a beautiful shade of clear salmon-pink with a brilliance unsurpassed and possibly unequaled under an electric light. The individual petals which are of good substance are very broad and are rounding at the tips. The flower usually measures five inches in diameter; has white throat faintly dotted with deep serise. Several blooms are open at one time and well placed on an always straight spike, four feet in height. Has broad heavy foliage and is a good propagator This grand new variety will add beauty and distinction to your garden. You are bound to want this in quantity. Get your start now. 


\section{A GOOD WORD FOR THE SOCIETIES.}

We find our membership in the following flower societies of vast benefit, in fact the bulletins received, alcne are worth the cost, and it is worth something also to know that you are helping to promote the advancement of your favorite flower.

If you can attend the meetings, or flower shows, of these organizations, you meet many congenial, cultured people, riding your same hobby, and these meetings and the acquaintances and friendships formed are worth more in pleasure than the shows themselves, fine as they are.

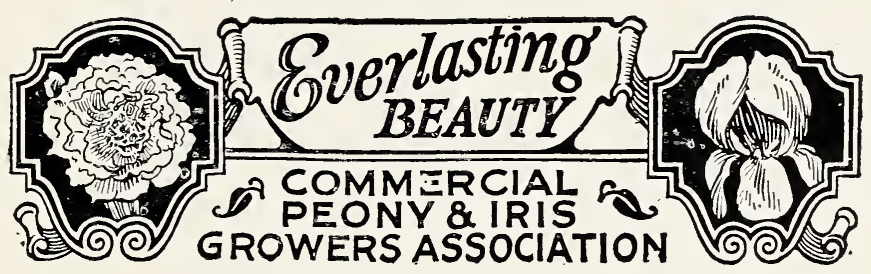

When the writer attended the Peony and Iris Growers Courtesy Meeting in Chicago last January, he found himself in distinguished company, surrounded by more than fifty of the leading growers of America, whose catalogues he had read and studied until he knew most of them by heart.

Now we know you will find it worth while and all it costs to join one or more of these societies, and we are going to offer you some special inducements to send your membership applications to us.

There are three "flower publications" that we wouldn't do without, and if there are any of them you don't take, you can save some money.

First is The Fower Grower, published at Calcium, N. Y., by Madison Cooper, and we really don't see how we could get along without it. The subscription price is $\$ 2.00$ per year, but if you will send us $\$ 1.25$ with your application and check for membership in any of these societies, it will be sent you for one year.

Next is The Garden Magazine and Home Builder, published by Doubleday, Page \& Company, at Garden City, N. Y., at $\$ 3.00$ per year. It is a little more "high brow" than The Flower Grower, but we find everything in it interesting, and believe you will, too. The illustrations are especially fine. Send us your application and check for membership in any of these soc:eties and we will accept your subscription to The Garden Magazine and Home Builder for one year for $\$ 2.00$, saving you $\$ 1.00$ on the transaction.

Last is Better Holmes and Gardens, published at Des Moines, Ia., by E. T. Meredith, Ex-Secretary of Agriculture. This magazine boasts a circulation of 900,000 , the largest of any flower publication in the world. Its subscription price is $75 \mathrm{c}$ per year, or three years for $\$ 1.50$, and they certainly give a big lot for the money. Send us your application and check for membership in any of these societies, and we will accept your subscription to Better Homes and Gardens for $90 \mathrm{c}$ for a three years' subscription.

There is no profit to us in any of the above transactions. We just want to help boost along the good work lone by these societies and magazines. 


\title{
THE AMERICAN PEONY SOCIETY.
}

Every Peony lover in America should become a member of this society. It was incorporated in 1904, and now numbers almost a thousand members, and should have many times that many. It has done much to stabilize and popularize Peony culture in this country. It issues four bulletins each year and has promised to issue a big Annual to be printed by The McFarland Horticultural Press at Harrisburg, Pa., this year. This Annual, with all it promises to contain, will be invaluable to every Peony fan.. A. M. Brand is President, and W. F. Christman is Secretary of this organization and the membership and dues are $\$ 3.00$ per year. Send us your application with check for $\$ 3.00$, payable to The American Peony Society, and we will forward it to the Treasurer.

\section{THE AMERICAN IRIS SOCIETY.}

(Annual dues \$3.00.)

The new member receives "Irises for the Beginner" and four other Bulletins during the year. Send us your application with check for $\$ 3.00$ payable to The American Iris Society," and we will forward it to the Treasurer.

\section{THE AMERICAN GLADIOLUS SOCIETY.}

(Annual dues $\$ 2.00$.)

They issue a bulletin each month, which in reality is a magazine. We don't see how they can gave so much for $\$ 2.00$. Send us your application with check for $\$ 2.00$, payable to "The American Gladiolus Society," and we will forward it to the Treasurer.

\section{THE AMERICAN DAHLIA SOCIETY}

\author{
(Annual dues $\$ 2.00$.)
}

This organization also issues four bulletins per year, which are mailed to all members. Every person interested in this beautiful flower will find it profitable to join The American Dahlia Society. Send us your application with check for $\$ 200$, paycble to "The Americs n Dahlia Society" and we will forward it to the Secretary.

\section{THE AMERICAN ROSE SOCIETY.}

(Annual dues \$3.00.)

This organization is noted for t? e beautiful annual (published by J. Horace McFarlend, of Harrisburg, Pa.) containing several hundred pages with many illustrations, some in colors, glorifying the American Beauty and later additions to the Rose family. It has the largest membership of any of the societies, owing licrgely, we think, not to the populs rity of the rose over the other flcwers, but to the popularity of the Annual. Send us your application with a creck for $\$ 300$, payable to "The American Rose Society," and we will forward it to the Secretary.

\section{APPLICATION FOR MENBERSHIP}

\section{I hereby make application for membership in}

The American ................... Society,

and attached find check for \$ . _. _ f for dues for 1927.

(Signed)

Address:

RECOMMENDED BY THE SAM CARPENTER GARDENS, OSWEGO, KANSAS 

